

\section{AVAILABILITY OF BOOKS AND MAPS OF THE U.S. GEOLOGICAL SURVEY}

Instructions on ordering publications of the U.S. Geological Survey, along with prices of the last offerings, are given in the current-year issues of the monthly catalog "New Publications of the U.S. Geological Survey." Prices of available U.S. Geological Survey publications released prior to the current year are listed in the most recent annual "Price and Availability List." Publications that are listed in various U.S. Geological Survey catalogs (see back inside cover) but not listed in the most recent annual "Price and Availability List" are no longer available.

Prices of reports released to the open files are given in the listing "U.S. Geological Survey Open-File Reports," updated monthly, which is for sale in microfiche from the U.S. Geological Survey, Books and Open-File Reports Section, Federal Center, Box 25425, Denver, CO 80225. Reports released through the NTIS may be obtained by writing to the National Technical Information Service, U.S. Department of Commerce, Springfield, VA 22161; please include NTIS report number with inquiry.

Order U.S. Geological Survey publications by mail or over the counter from the offices given below.

\section{BY MAIL}

\section{Books}

Professional Papers, Bulletins, Water-Supply Papers, Techniques of Water-Resources Investigations, Circulars, publications of general interest (such as leaflets, pamphlets, booklets), single copies of Earthquakes \& Volcanoes, Preliminary Determination of Epicenters, and some miscellaneous reports, including some of the foregoing series that have gone out of print at the Superintendent of Documents, are obtainable by mail from

\section{U.S. Geological Survey, Books and Open-File Reports Federal Center, Box 25425 Denver, CO 80225}

Subscriptions to periodicals (Earthquakes \& Volcanoes and Preliminary Determination of Epicenters) can be obtained ONLY from the

\section{Superintendent of Documents \\ Government Printing Ofnce \\ Washington, D.C. 20402} ments.)

(Check or money order must be payable to Superintendent of Docu-

\section{Maps}

For maps, address mail orders to

\section{U.S. Geological Survey, Map Distribution \\ Federal Center, Box 25286 \\ Denver, CO 80225}

Residents of Alaska may order maps from

Alaska Distribution Section, U.S. Geological Survey,

New Federal Bullding - Box 12

101 Twelfth Ave., Fairbanks, AK 99701

\section{OVER THE COUNTER}

\section{Books}

Books of the U.S. Geological Survey are available over the counter at the following Geological Survey Public Inquiries Offices, all of which are authorized agents of the Superintendent of Documents:

- WASHINGTON, D.C.--Main Interior Bldg., 2600 corridor, 18 th and C Sts., NW.

- DENVER, Colorado-Federal Bldg., Rm. 169, 1961 Stout St.

- LOS ANGELES, California--Federal Bldg., Rm.7638, $300 \mathrm{~N}$. Los Angeles St.

- MENLO PARK, Californla--Bldg. 3 (Stop 533), Rm. 3128, 345 Middlefield Rd.

- RESTON, Virginia--503 National Center, Rm. 1C402, 12201

Sunrise Valley Dr.

- SALT LAKE CITY, Utah--Federal Bldg., Rm. 8105, 125 South State St.

- SAN FRANCISCO, Callfornia--Customhouse, Rm. 504, 555 Battery St.

- SPOKANE, Washington--U.S. Courthouse, Rm. 678, West 920 Riverside Ave..

- ANCHORAGE, Alaska--Rm. 101, 4230 University Dr.

- ANCHORAGE, Alaska--Federal Bldg, Rm. E-146, 701 C St.

\section{Maps}

Maps may be purchased over the counter at the U.S. Geological Survey offices where books are sold (all addresses in above list) and at the following Geological Survey offices:

- ROLLA, Missouri--1400 Independence Rd.

- DENVER, Colorado--Map Distribution, Bldg. 810, Federal Center

- FAIRBANKS, Alaska--New Federal Bldg., 101 Twelfth Ave. 
Chapter $\mathrm{H}$

\title{
Regional Diagenesis of Sandstones in the Upper Jurassic Morrison Formation, San Juan Basin, New Mexico and Colorado: Geologic, Chemical, and Kinetic Constraints
}

\author{
By PAULA L. HANSLEY
}

A multidisciplinary approach to research studies of sedimentary rocks and their constituents and the evolution of sedimentary basins, both ancient and modern 


\title{
DEPARTMENT OF THE INTERIOR
}

\author{
MANUEL LUJAN, JR., Secretary
}

U.S. GEOLOGICAL SURVEY

Dallas L. Peck, Director

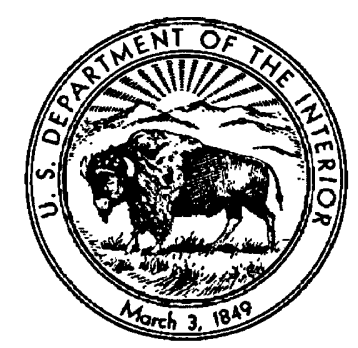

Any use of trade, product, or firm names in this publication is for descriptive purposes only and does not imply endorsement by the U.S. Government.

UNITED STATES GOVERNMENT PRINTING OFFICE: 1990

For sale by the

Books and Open-File Reports Section

U.S. Geological Survey

Federal Center

Box 25425

Denver, CO 80225

\section{Library of Congress Cataloging-In-Publication Data}

Hansley, Paula L.

Regional diagenesis of sandstones in the Upper Jurassic Morrison

Formation, San Juan Basin, New Mexico and Colorado : geologic, chemical, and kinetic constraints / by Paula L. Hansley

p. cm. - (U.S. Geological Survey bulletin ; 1808)

Includes bibliographical references.

Supt. of Docs. no.: | 19.3:1808-H

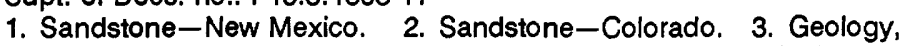

Stratigraphic-Jurassic. 4. Morrison Formation. I. Title. II. Series.

QE75.89 no. 1808

[QE471.15.S25]

$557.3 \mathrm{~s}-\mathrm{dc} 20$

[552'.5]

89-600194 


\section{CONTENTS}

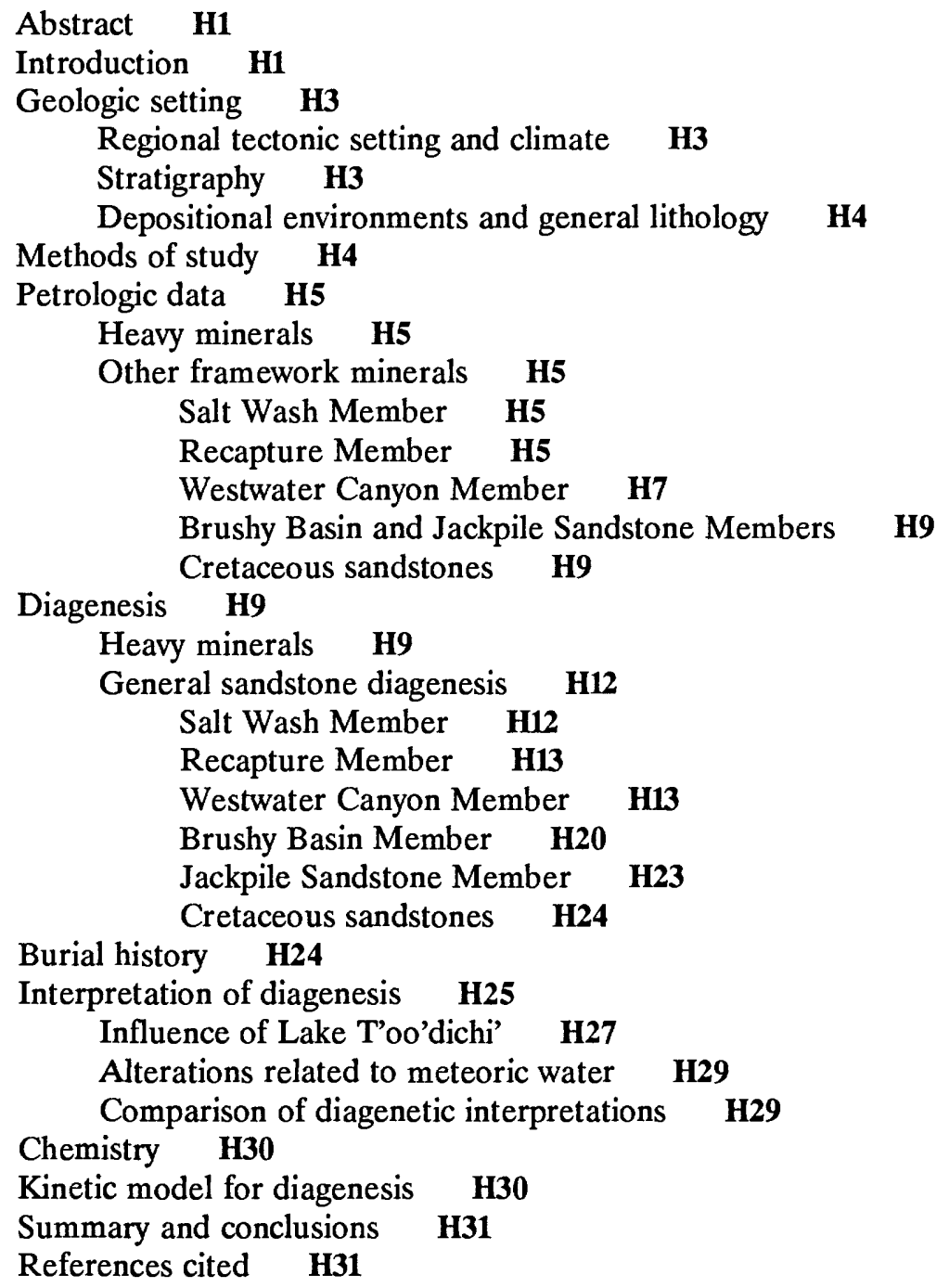

\section{FIGURES}

1. Map showing major tectonic features, outcrop areas of rocks of Morrison Formation, and location of sampled outcrops and cores, San Juan basin $\mathbf{H} 2$

2. Ternary diagram showing classification of sandstones in the Salt Wash, Recapture, Westwater Canyon, and Brushy Basin Members of the Morrison Formation $\quad \mathrm{H8}$

3-5. Photomicrographs showing:

3. Felsic volcanic rock fragment in the Westwater Canyon Member H9

4. Vitric textures preserved in analcime-cemented sandstone of the Brushy Basin Member $\mathbf{H 1 0}$

5. Anti-rapakivi textures of detrital plagioclase grains H11

6. Scanning electron micrograph showing deeply etched garnet from the Morrison Formation $\quad \mathbf{H 1 2}$ 
7. Diagram showing occurrence of garnet textures in the Morrison Formation H13

8. Maps showing regional distribution of major authigenic clay minerals in members of the Morrison Formation $\mathrm{H16}$

9. Diagram showing paragenesis of major authigenic phases and diagenetic events in the Morrison Formation $\mathbf{H 1 9}$

10. X-ray diffractogram of authigenic nonferroan chlorite in sandstone of the Westwater Canyon Member $\mathbf{H 1 9}$

11-12. Scanning electron micrographs showing:

11. Clinoptilolite crystals in a sandstone pore of the Westwater Canyon Member H19

12. Clinoptilolite intergrown with authigenic idiomorphic quartz in sandstone pore of the upper part of the Westwater Canyon Member H20

13-15. Photomicrographs showing:

13. Analcime-cemented sandstones in the Morrison Formation H21

14. "Chessboard albite" grain in sandstone of the upper part of the Westwater Canyon Member $\mathbf{H 2 2}$

15. Potassium feldspar overgrowths $\mathbf{H 2 2}$

16. X-ray diffractogram of well-ordered illite/smectite in a sandstone near the top of the Westwater Canyon Member $\quad \mathbf{H 2 3}$

17. Scanning electron micrograph showing authigenic chlorite rosette and intergrown illitic/smectite filaments from the Westwater Canyon Member $\mathbf{H 2 3}$

18-21. Photomicrographs showing:

18. Several generations of chalcedony cement in sandstone of the Brushy Basin Member $\mathbf{H} 23$

19. Authigenic pore-filling albite overgrowths in a sandstone of the Brushy Basin Member $\mathbf{H 2 3}$

20. Detrital plagioclase grain with albite overgrowth and later chalcedony cement $\mathbf{H} 24$

21. Pore-filling kaolinite cement in sandstone $\mathbf{H 2 4}$

22-24. Scanning electron micrographs showing:

22. Illite/smectite in sandstone of the Brushy Basin Member $\mathbf{H 2 4}$

23. Intergrowth of illitic illite/smectite needles and authigenic quartz in sandstone of the Brushy Basin Member $\mathbf{H 2 5}$

24. Illitic overgrowths on clinoptilolite in sandstone pore of the Brushy Basin Member $\mathbf{H 2 5}$

25. Map showing vitrinite reflectance values for coals in the Upper Cretaceous Dakota Sandstone and Fruitland Formation, San Juan basin $\quad$ H26

26. Scanning electron micrograph showing illitic illite/smectite on margins of analcime cement in sandstone pore of the Westwater Canyon Member $\mathbf{H 2 7}$

27. Ion activity diagram showing the relations between some common authigenic minerals in the Morrison Formation $\mathbf{H 2 8}$

\section{TABLES}

1. Petrographic data derived from point counts of selected thin sections

2. Results of X-ray diffraction analysis of the $<2-\mu \mathrm{m}$ fraction of selected sandstones H14 
CONVERSION FACTORS FOR SOME SI METRIC AND U.S. UNITS OF MEASURE

\begin{tabular}{lll}
\hline \multicolumn{1}{c}{ To convert from } & \multicolumn{1}{c}{ To } & \multicolumn{1}{c}{ Multiply by } \\
\hline Feet $(\mathrm{ft})$ & Meters $(\mathrm{m})$ & 0.3048 \\
Miles $(\mathrm{mi})$ & Kilometers $(\mathrm{km})$ & 1.609 \\
Pounds $(\mathrm{lb})$ & Kilograms $(\mathrm{kg})$ & 0.4536 \\
Degrees Fahrenheit $\left({ }^{\circ} \mathrm{F}\right)$ & Degrees Celsius $\left({ }^{\circ} \mathrm{C}\right)$ & Temp ${ }^{\circ} \mathrm{C}=\left(\right.$ temp $\left.{ }^{\circ} \mathrm{F}-32\right) / 1.8$ \\
\hline
\end{tabular}





\title{
Regional Diagenesis of Sandstones in the Upper Jurassic Morrison Formation, San Juan Basin, New Mexico and Colorado: Geologic, Chemical, and Kinetic Constraints
}

\author{
By Paula L. Hansley
}

\section{Abstract}

Early authigenic mineral assemblages (such as zeolite, silica, and feldspar cements) and vitroclastic textures are extraordinarily well preserved in upper sandstones of the Upper Jurassic Morrison Formation in the San Juan basin of New Mexico and Colorado. Early diagenetic reactions were driven by rapid dissolution of rhyolitic volcanic ash, which was incorporated into Morrison sediments at the time of deposition. The distributions of these authigenic minerals were controlled, in part, by chemical gradients in a large saline, alkaline lake (Lake T'oo'dichi') that existed in late Morrison time. Sandstones on lake margins were cemented by smectite and silica, whereas sandstones nearer the lake center, in which waters were most saline and alkaline, were cemented by zeolites. Diagenetic alterations in sandstones were promoted by alkaline interstitial waters that emanated from adjacent fine-grained, tuffaceous lake beds. Metastable phases that precipitated first were replaced relatively quickly by more stable, ordered phases in the geochemically favorable environment of the closed basin setting. Sandstones in the lower part of the Morrison Formation contained less ash at the time of deposition and thus have fewer diagenetic alterations. Diagenesis was dominated by precipitation of early pore-filling calcite cement and mixed-layer clay minerals. In the northern part of the basin, quartz is an abundant cement.

Vitrinite reflectance values for Cretaceous coals indicate that the Morrison Formation has remained relatively cool at basin margins throughout diagenesis. Elevation of temperatures above the geothermal gradient was provided by the influx of warm, deep-basin waters that locally modified early diagenetic assemblages during burial diagenesis. In organic- (and commonly also uranium ore-) bearing sand-

Manuscript approved for publication, June 7, 1989. stones located primarily in the southern part of the basin, complex diagenetic assemblages resulted from water/rock reactions involving soluble organic complexes. Uplift of recharge areas promoted the downdip migration of meteoric waters through permeable sandstones of the Morrison in the Early Cretaceous and late Tertiary that caused widespread precipitation of kaolinite.

\section{INTRODUCTION}

The Upper Jurassic Morrison Formation is the major uranium- and vanadium-bearing unit on the Colorado Plateau and, as such, has been the focus of numerous sedimentologic, petrologic, and geochemical studies. (See Adams and Saucier, 1981, and TurnerPeterson and others, 1986, for bibliographies.) As a result, most research has concentrated on uranium orebearing strata; few studies have examined the regional petrology of the Morrison Formation. The major goal of the research discussed in this report was to extend a petrologic study of the Morrison Formation in eight U.S. Geological Survey (USGS) cores taken from drill holes in the Grants uranium region (fig. 1) in the southwestern part of the San Juan basin (Hansley, 1986a, b) to the rest of the basin in order to determine if observed diagenetic alteration patterns identified in the cores reflect basinwide trends. A second objective was to use the mineralogy and paragenetic relationships of diagenetic assemblages to infer chemical processes responsible for observed postdepositional modifications of sandstones.

In order to accomplish these goals, sandstone samples were collected from 22 outcrops of the Morrison Formation and overlying Cretaceous sandstones around the margins of the basin (fig. 1). The Galisteo Dam 
section is $30 \mathrm{~km}$ northeast of Albuquerque, just east of the area shown in figure 1. In addition, sandstones from 15 cores in the southern part of the basin were examined to enlarge the core data set. New petrologic data were combined with previously published data to facilitate interpretations of basinwide patterns.

Virtually all outcrop localities were barren of uranium ore, with the exception of small uraniumvanadium claims in the Salt Wash Member of the Mor- rison near Oak Springs and in the Westwater Canyon Member of the Morrison at the Dennison-Bunn outcrop. Some uranium enrichment (discrete coffinite) was noted in the cores. A lack of ore-bearing samples was not a detriment to this study, however, because primary uranium mineralization in the Morrison Formation was a very early diagenetic process (Ludwig and others, 1984), and most diagenetic alterations discussed herein occurred subsequent to ore formation or formed in parts

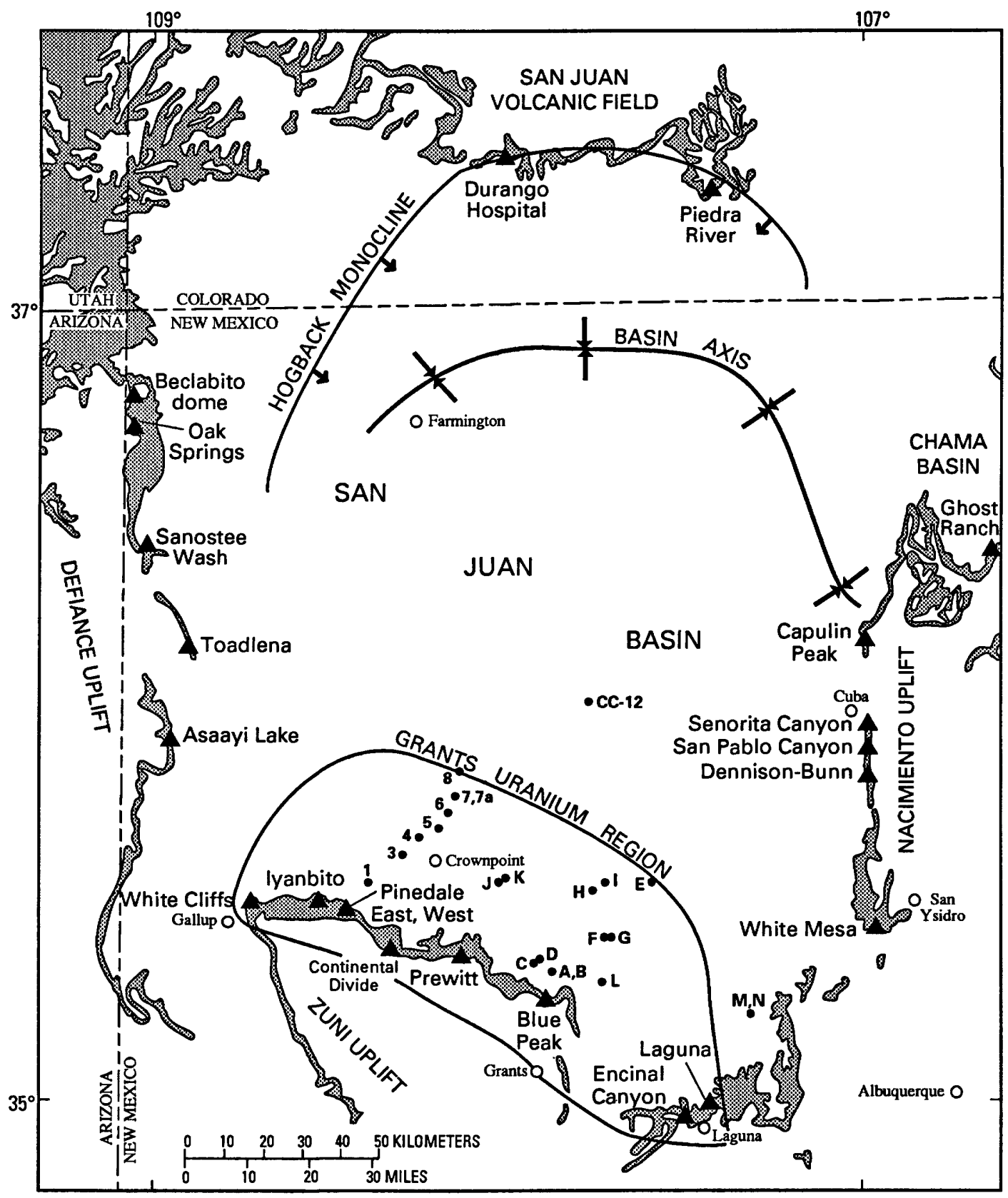

Figure 1. Major tectonic features and outcrop areas of rocks of Morrison Formation, San Juan basin. Location of sampled outcrops (triangles) and cores (solid circles) also shown. Numbers (1-8) indicate USGS core localities; letters (A-N) indicate other core localities (S.A. Adams, Colorado School of Mines). Tectonic features from Kelley and Clinton (1960); base map modified from Turner-Peterson (1986, fig. 1). 
of the basin where the Morrison Formation is not known to contain ore. Furthermore, uranium enrichment in some of the cores and descriptions of uranium ore zones in previous studies provided a basis for comparing the petrology of barren sandstones to mineralized sandstones.

Acknowledgments. - I express appreciation to Isabelle Brownfield and Gary Skipp, USGS, for careful laboratory preparation of samples and for running heavymineral separations and clay-mineral diffraction patterns. In addition, I thank Neil Fishman and Christine Turner-Peterson, USGS, for furnishing some samples and thin sections from the northern and western parts of the basin.

\section{GEOLOGIC SETTING}

\section{Regional Tectonic Setting and Climate}

Although formation of the San Juan basin dates back to the Paleozoic, its present configuration reflects Laramide deformation (Kelley, 1951). In the Late Jurassic, the San Juan basin was bounded by the Zuni uplift to the south and the Defiance uplift to the west, and small positive areas also existed in southeastern Utah and southwestern Colorado (Santos and Turner-Peterson, 1986). Although the Defiance and Zuni uplifts may have been moderately active, furnishing local detritus to the basin during Morrison deposition (Santos and TurnerPeterson, 1986), major source areas for the Morrison were a magmatic arc west of the Colorado Plateau in present-day southeastern California, southwestern Arizona, and northwestern Sonora, Mexico (Hamilton, 1978; Dickinson, 1981), and the Mogollon uplift that extended from central Arizona into western New Mexico (Cooley and Davidson, 1963; Martinez, 1979; Lowy, 1982). In these source areas, volcanic, intrusive igneous, metamorphic, and minor sedimentary strata furnished detritus to northeastward- and eastward-flowing streams. Abundant rhyolitic to dacitic volcanic ash (Cadigan, 1967) that was blown eastward from volcanoes in the magmatic arc into the San Juan basin comprised a large part of the original matrix (now largely smectite) of Morrison sediments (Waters and Granger, 1953). Thick sequences $(>100 \mathrm{~m})$ comprised predominantly of altered ash beds as thick as a meter in lacustrine facies of the Brushy Basin Member attest to the enormous volumes of ash that were deposited (Turner-Peterson, 1987).

The climate during Morrison time was semiarid as evidenced by sedimentary structures, fluvial style (such as ephemeral, braided streams), the presence of eolian deposits in the lower part of the Morrison, and saline, alkaline lake deposits in the upper part of the Morrison (Bell, 1983, 1986; Turner-Peterson, 1987).

\section{Stratigraphy}

The Morrison Formation consists of five formal members in the basin (in ascending order): the Recapture, Westwater Canyon, Brushy Basin, Jackpile Sandstone, and Salt Wash. (The lowest of these, the Salt Wash Member, is only in the Four Corners region (Craig and others, 1955).) The contacts of members with each other are sharp to gradational and occasionally interfingering. The Morrison is overlain unconformably throughout most of the basin by the Upper Cretaceous Dakota Sandstone or by the Lower Cretaceous Burro Canyon Formation in the Chama basin and in the northern San Juan basin. The Jackpile is overlain by fluvial sandstones at the base of the Dakota Sandstone in the southeastern part of the basin (Aubrey, 1986). The Morrison is underlain by various formations of the Middle Jurassic San Rafael Group throughout the region (Turner-Peterson, 1986).

The average thickness of the Morrison Formation in the basin is $150 \mathrm{~m}$ (Turner-Peterson and Fishman, 1986). The Morrison thins erosionally and depositionally to the south where it is truncated by the Dakota Sandstone; hence, the Dakota rests on progressively older beds of the Morrison to the south. In the southwestern corner of the basin, the Brushy Basin has been eroded completely and the Dakota rests on the Westwater Canyon Member (Turner-Peterson, 1986).

The Salt Wash Member is present in the northwestern part of the basin where it reaches a thickness of $61 \mathrm{~m}$ (Condon and Peterson, 1986). It thins to the south and interfingers locally with the lower part of the Recapture Member. The Recapture Member is present throughout the basin, but it is not differentiated from the Beclabito Member of the underlying Middle Jurassic Wanakah Formation in the Cuba area (Condon and Peterson, 1986). The Recapture lies directly under the Brushy Basin Member in the Durango area (TurnerPeterson, 1987). The Recapture is as thick as $152 \mathrm{~m}$ on the west side of the basin. The Westwater Canyon Member thins to the south, north, and east; it pinches out depositionally south of the San Juan basin and north of the New Mexico-Colorado State line and is last recognized as far east as Galisteo Dam (Turner-Peterson, 1987). The Westwater Canyon Member is thickest (about $100 \mathrm{~m}$ ) in outcrop along the western margin of the basin (Turner-Peterson, 1987, fig. 11) and is as thick as $135 \mathrm{~m}$ in the subsurface northeast of Gallup (Kirk and Condon, 1986). The Brushy Basin Member is thickest in the vicinity of Durango (fig. 1), where it is as thick as about $105 \mathrm{~m}$ (Turner-Peterson, 1987, fig. 32). 
In the southeastern part of the basin, the Jackpile Sandstone Member lies above the Brushy Basin Member just under a regional Jurassic-Cretaceous unconformity. The type Jackpile is exposed in the Laguna area where it locally contains uranium ore and is as thick as $65 \mathrm{~m}$ (Owen and others, 1984). From Laguna, Owen and others extended the Jackpile north to Cuba and east to the Galisteo Dam area. The Jackpile was deposited along a syndepositional syncline (Hilpert and Moench, 1960), the trace of which trends to the northeast into the subsurface where a sandstone thought to be the Jackpile continues to appear at the top of the Morrison Formation (Flesch, 1975). This correlation has been extended to sandstones at the top of the Morrison Formation in surface exposures along the Nacimiento uplift (Ruetschilling, 1973; Woodward and Schumacher, 1973; Santos, 1975). Flesch (1975) mapped 7-30 m of Jackpile near San Ysidro, and Santos (1975) mapped 0-50 m of Jackpile in the San Ysidro area. Others, however, have questioned this identification because the Jackpile occupies the same stratigraphic position as the fluvial Burro Canyon Formation in the Chama basin (Aubrey, 1986). For example, Saucier (1974) extended the Jackpile northeastward from Laguna to the San Ysidro area, but, from San Ysidro along the Nacimiento uplift to the northeast toward the Chama basin, he replaced the Jackpile with the Burro Canyon Formation. Stratigraphic correlation is difficult because these two fluvial units are similar in composition except for a lack of conglomerate in the Jackpile (Flesch, 1975; Aubrey, 1986). The reason for this similarity is that the Burro Canyon consists mostly of reworked Morrison detritus (Santos, 1975).

Recently, the Encinal Canyon Member of the Dakota Sandstone, also a fluvial unit, was named formally in the southeastern San Juan basin (Aubrey, 1986). It locally cuts out the Jackpile in the southeastern part of the basin and includes parts of what have been called Burro Canyon Formation and Jackpile Sandstone Member along the Nacimiento uplift (Aubrey, 1986). In its type area, the Encinal Canyon Member includes part of the Jackpile as defined by Grant and Owen (1974). Where these fluvial units occur together, the sandon-sand relationship is difficult to decipher because of the quartzose composition of all three units. The Jackpile is less conglomeratic and may contain more feldspar and volcanic-rock fragments than the Cretaceous units. The Burro Canyon Member is conglomeratic and contains abundant kaolinite, tripolitic chert (Santos, 1975), and oolitic, fossiliferous, silicified limestone pebbles (Ridgely, 1977). Generally, sandstones in the Encinal Canyon Member contain distinctive white, chalky chert pebbles (Aubrey, 1986). The uppermost Jurassic and Cretaceous stratigraphy used in this report follows that of Aubrey (1986, fig. 6) in the eastern part of the basin.

\section{Depositional Environments and General Lithology}

The Salt Wash Member was deposited by meandering and braided streams that originated in source areas to the west of the Colorado Plateau (Peterson, 1984). The Salt Wash consists of light-greenish-gray to light-brown, very fine to medium grained, moderately well sorted sandstone interbedded with greenish-gray to reddish-brown mudstone.

The Recapture Member was deposited in fluvial, lacustrine, and eolian environments (Condon and Peterson, 1986). Streams generally came into the basin from the southwest. The Recapture consists of very fine to fine grained (occasionally medium grained), light-gray to pale-reddish-brown sandstone beds interbedded with variegated red-brown to purplish silty mudstone and claystone beds.

The Westwater Canyon Member was deposited by braided streams that flowed northeastward to southeastward across the basin from distant source areas to the west and southwest of the Colorado Plateau (TurnerPeterson, 1986). Sandstones of the Westwater Canyon Member are poorly to well sorted, fine to medium grained, and locally conglomeratic. The Recapture and Westwater Canyon Members are reddish in outcrop owing to late Tertiary oxidation but are generally a drab gray in the subsurface (Turner-Peterson, 1986). Interbedded greenish-gray mudstones and claystones are bentonitic.

Sediments of the Brushy Basin Member were deposited in a classic saline, alkaline lake, Lake T'oo'dichi' (Turner-Peterson, 1987), in which mudflat facies around the margins grade into more saline, playalake facies toward the center of the basin (Bell, 1983, 1986; Turner-Peterson, 1987). Fluvial sandstones are light brown to gray and are similar in composition to sandstones of the Westwater Canyon Member. Sandstones are interbedded with thick sequences of bentonitic to zeolitic mudstone, claystone, altered tuff beds, and thin limestone units.

The Jackpile Sandstone Member was deposited by braided streams (Moench and Schlee, 1967) that flowed in a northeasterly direction at Laguna and in an easterly direction along the Nacimiento uplift (Flesch, 1975; Owen and others, 1984). Sandstone units are chalky gray, white to yellow, fine to medium grained, and locally conglomeratic and contain minor interbedded claystone. Silicified or coalified plant remains are locally present.

\section{METHODS OF STUDY}

Sandstone samples (217) were collected from 22 outcrops of the Morrison Formation on the margins of 
the San Juan basin. Some localities were sampled in detail, and others were sampled sparsely to check variations in petrology. Petrographic thin sections of outcrop samples were impregnated with blue-dyed epoxy and stained with sodium cobaltinitrate for potassium feldspar identification and with Alizarin Red-S for calcite identification. Point counts ( 300 points per section) were made of representative thin sections for sandstone classification. Additional petrographic thin sections (84) (donated by S.S. Adams, Colorado School of Mines) from 15 cores in the southern part of the basin were examined; point counts were not made of these thin sections.

Heavy-mineral separations of the $<60>200$ micron fraction of selected fine- to medium-grained samples were made in Bromoform (S.G. 2.87). The magnetic fraction was removed from the heavy fraction with a hand magnet, and the remaining nonmagnetic fraction (or a split thereof) was mounted with Canada balsam on a petrographic slide. Point counts of the heavy-mineral mounts were not conducted during this study. (See Hansley, 1986a, for point counts of samples from the USGS cores.)

Selected samples were examined with a Cambridge Stereoscan Mark 2 scanning electron microscope (SEM) with an attached Tracor Northern energy-dispersive system so that textural (paragenetic) relationships among authigenic minerals in sandstone pores could be described and the genetic nature (authigenic versus detrital) of clay minerals determined.

The $<2-\mu \mathrm{m}$ fraction of selected samples was analyzed by $\mathrm{X}$-ray diffraction for determination of clay mineralogy. Three X-ray diffractograms were generated from each sample-air dried, glycolated, and $550{ }^{\circ} \mathrm{C}$ runs - in order to make clay-mineral identifications. The percentage of illite in interstratified illite/smectite (I/S) was determined by measuring the 001/002 and 002/003 peak positions (Reynolds, 1980); the notation of 0.7I means 70 percent illite in $\mathrm{I} / \mathrm{S}$. The presence of perfect ordering (ISIS, IIIS, and so forth) was evaluated by looking for a superlattice peak, noting positions of nonintegral peaks, and comparing the results to published (Reynolds, 1980) and unpublished (Maynard Slaughter, Colorado School of Mines, 1987) clay-mineral tables.

\section{PETROLOGIC DATA}

\section{Heavy Minerals}

Tourmaline, zircon, garnet, staurolite, apatite, and iron-titanium oxides comprise the bulk of heavy-mineral suites. Minor heavy-mineral species include epidote, rutile, hornblende, sphene, and monazite. The most notable change in composition among the members is the appearance of abundant staurolite in the Westwater Canyon and Brushy Basin Members, as compared to a lack of staurolite in the Salt Wash Member and a trace of staurolite in the Recapture Member. In general, staurolite is more abundant in the Westwater Canyon and Brushy Basin Members (including the Jackpile Sandstone Member) in the eastern part of the basin than in the rest of the basin, but it is notably absent at Galisteo Dam. Epidote is present in the Recapture and Westwater Canyon Members along the Nacimiento uplift and is most abundant in rocks at Senorita Canyon. Sphene was noted only at Galisteo Dam. Garnet is common throughout the Morrison except at the Durango Hospital section, where the Recapture and Brushy Basin Members contain no garnet. The Middle and Upper Jurassic Junction Creek Sandstone, which underlies the Recapture Member at Durango, does not contain garnet but does contain distinctive green hornblende not present in the overlying Morrison Formation.

Only a few Cretaceous samples were analyzed for heavy minerals. The marine Oak Canyon Member of the Dakota Sandstone is characterized by zircon and tourmaline; no garnet or apatite was observed. The underlying Encinal Canyon Member contains abundant zircon, tourmaline, and staurolite, but no garnet was noted in the samples analyzed.

\section{Other Framework Minerals}

The detrital mineralogy of sandstones in the Morrison Formation is also relatively consistent around the basin. Sandstones were classified according to Folk's scheme (1974). Classifications generally agree with those of previous workers (Cadigan, 1967; Schmitt, 1982; Steele, 1984a, b). Point counts of selected thin sections are shown in table 1.

\section{Salt Wash Member}

Sandstones of the Salt Wash Member are moderately well sorted, fine-grained subarkoses (fig. $2 A$ ) composed of quartz, microcline, orthoclase, sodic plagioclase, sanidine(?), and various rock fragments. The most common rock fragments are chert, limestone (micrite), silicified limestone, and fine-grained varieties such as siltstone and shale. Igneous (plutonic) and metamorphic (quartzite) lithic fragments are rare. Most plagioclase is untwinned; some displays albite twinning or zoning.

\section{Recapture Member}

Sandstones of the Recapture Member are mainly subarkoses and lithic arkoses (fig. $2 B$ ) that have compositions similar to those of the Westwater Canyon 
Table 1. Petrographic data derived from point counts of selected thin sections

[Data in volume percent; based on 300 points per thin section. Kdec, Encinal Canyon Member of Dakota Sandstone; Kbc, Burro Canyon Formation; Jmu, Morrison Formation (undifferentiated). Morrison Formation: Jmj, Jackpile Sandstone Member, Jmb, Brushy Basin Member; Jmw, Westwater Canyon Member, Jmr, Recapture Member; Jmsw, Salt Wash Member. Petrographic components: frag, fragments; Musc, muscovite; min, minerals; Anhy, anhydrite; Zeol, zeolites; ovgr, overgrowths; Chal, chalcedony]

\begin{tabular}{|c|c|c|c|c|c|c|c|c|c|c|c|c|c|c|c|c|c|c|c|}
\hline $\begin{array}{l}\text { Strat } \\
\text { unit }\end{array}$ & $\begin{array}{l}\text { Sample } \\
\text { number }\end{array}$ & Qtz & Kspar & Plag & $\begin{array}{l}\text { Rock } \\
\text { frag }\end{array}$ & Biotite & Ausc & $\begin{array}{c}\text { Heav } \\
\text { min }\end{array}$ & Calcite & & & Zeol & $\begin{array}{l}\text { Qtz } \\
\text { ovgr }\end{array}$ & $\begin{array}{c}\text { Kspar } \\
\text { ovgr }\end{array}$ & $\begin{array}{l}\text { Albite } \\
\text { ovgr }\end{array}$ & Chal & \multicolumn{3}{|c|}{ ClayHematite Voic } \\
\hline \multicolumn{20}{|c|}{ Senorita Canyon } \\
\hline $\mathrm{Jmb}$ & Sc-1 & 144 & 12 & 15 & 25 & 0 & 2 & 0 & 0 & 0 & 0 & 50 & 4 & 0 & 0 & 1 & 35 & 0 & 12 \\
\hline $\mathrm{Jmb}$ & Sc-2 & 121 & 6 & 15 & 56 & 0 & 0 & 0 & 0 & 0 & 0 & 21 & 33 & 0 & 0 & 1 & 37 & 0 & 10 \\
\hline Jmw & Sc-10 & 119 & 53 & 33 & 37 & 0 & 0 & 0 & 0 & 0 & 0 & 0 & 11 & 0 & 0 & 7 & 1 & 0 & 39 \\
\hline Jmw & Sc-11 & 134 & 19 & 10 & 29 & 0 & 0 & 0 & 106 & 0 & 0 & 0 & 0 & 0 & 0 & 2 & 0 & 0 & 0 \\
\hline Jmw & Sc-13 & 132 & 29 & 11 & 13 & 0 & 0 & 0 & 113 & 0 & 0 & 0 & 0 & 0 & 0 & 1 & 1 & 0 & 0 \\
\hline \multicolumn{20}{|c|}{ Capulin Peak } \\
\hline$\overline{K b c}$ & $\mathrm{Cp}-1$ & 209 & 3 & 0 & 23 & 0 & 0 & 0 & 0 & 0 & 0 & 0 & 2 & 0 & 0 & 0 & 7 & 0 & 56 \\
\hline $\mathrm{Kbc}$ & $\mathrm{Cp}-2$ & 179 & 24 & 0 & 19 & 0 & 0 & 0 & 0 & 0 & 0 & 0 & 0 & 0 & $\mathbf{0}$ & 44 & 12 & 0 & 16 \\
\hline Jmw & $\mathrm{Cp}-8$ & 140 & 51 & 3 & 19 & 0 & 0 & 0 & 50 & 0 & 0 & 0 & 0 & 0 & $\mathbf{0}$ & 1 & 27 & 0 & 9 \\
\hline $\mathrm{Jmw}$ & $\mathrm{Cp}-9$ & 194 & 25 & 12 & 25 & 0 & 0 & 0 & 10 & 0 & 0 & 0 & 0 & 0 & 0 & 0 & 12 & 0 & 22 \\
\hline $\mathrm{Jmw}$ & $\mathrm{Cp}-10$ & 127 & 28 & 11 & 23 & 0 & 0 & 0 & 107 & 0 & 0 & 0 & 0 & 0 & 0 & 0 & 0 & 0 & 0 \\
\hline $\mathrm{Jmw}$ & $\mathrm{Cp}-11$ & 144 & 43 & 8 & 20 & 0 & 0 & 0 & 6 & 0 & 0 & 0 & 0 & 0 & $\mathbf{0}$ & 0 & 19 & 0 & 57 \\
\hline Jmw & Cp-14 & 141 & 42 & 5 & 16 & 0 & 0 & 0 & 89 & 0 & 0 & 0 & 0 & 0 & 0 & 0 & 5 & 0 & 2 \\
\hline \multicolumn{20}{|c|}{ San Pablo Canyon } \\
\hline $\mathrm{Jmj}$ & $\mathrm{Sp}-2$ & 138 & 29 & 16 & 40 & 0 & 0 & 0 & 0 & 0 & 0 & 0 & 75 & 0 & 0 & 1 & 0 & 0 & 1 \\
\hline $\mathrm{Jmw}$ & $\mathrm{Sp}-5$ & 138 & 22 & 21 & 40 & 0 & 0 & 0 & 0 & 0 & 0 & 4 & 54 & 3 & 0 & 2 & 9 & 0 & 7 \\
\hline \multicolumn{20}{|c|}{ Durango Hospital } \\
\hline $\mathrm{Jmr}$ & Dh-2 & 112 & 11 & 7 & 9 & 0 & 0 & 0 & 11 & 25 & 6 & 0 & 117 & 0 & 0 & 0 & 2 & 0 & 0 \\
\hline Jmr & $\mathrm{Dh}-3$ & 136 & 25 & 7 & 9 & 0 & 0 & 0 & 20 & 0 & 0 & 0 & 66 & 0 & 0 & 0 & 37 & 0 & 0 \\
\hline $\mathrm{Jmr}$ & $\mathrm{Dh}-4$ & 138 & 11 & 14 & 6 & 0 & 0 & 0 & 8 & 0 & 0 & 0 & 84 & 0 & 0 & 3 & 35 & 0 & 1 \\
\hline Jmr & Dh-5 & 162 & 12 & 12 & 8 & 0 & 0 & 0 & 70 & 0 & 0 & 0 & 29 & 0 & 0 & 0 & 2 & 0 & 0 \\
\hline $\mathrm{Jmr}$ & Dh-6 & 151 & 10 & 13 & 9 & 0 & 0 & 0 & 47 & 0 & 0 & 0 & 55 & 0 & 0 & 3 & 12 & 0 & 0 \\
\hline $\mathrm{Jmb}$ & $\mathrm{Dh}-8$ & 153 & 9 & 18 & 11 & 0 & 0 & 0 & 3 & 0 & 0 & 0 & 25 & 0 & 20 & 0 & 22 & 0 & 39 \\
\hline $\mathrm{Jmb}$ & Dh-11 & 79 & 14 & 16 & 1 & 0 & 0 & 0 & 3 & 0 & 0 & 1 & 0 & 0 & 0 & 169 & 2 & 0 & 0 \\
\hline \multicolumn{20}{|c|}{ White Mesa } \\
\hline$\overline{\mathrm{Jmj}}$ & $\mathrm{Wm}-1 \mathrm{a}$ & 204 & 17 & 0 & 18 & 0 & 0 & 0 & 0 & 0 & 0 & 0 & 1 & 0 & 0 & 8 & 12 & 0 & 40 \\
\hline $\mathrm{Jmj}$ & Wm-1 & 145 & 30 & 23 & 35 & 0 & 0 & 0 & 0 & 0 & 0 & 0 & 10 & 1 & 0 & 56 & 0 & 0 & 0 \\
\hline $\mathrm{Jm} \hat{j}$ & Wm-2 & 186 & 18 & 9 & 24 & 0 & 0 & 0 & 0 & 0 & 0 & 0 & 0 & 0 & 0 & 0 & 45 & 0 & 18 \\
\hline $\mathrm{Jmb}$ & Wm-3 & 112 & 25 & 17 & 48 & 0 & 0 & 0 & 76 & 0 & 0 & 0 & 0 & 0 & 0 & 0 & 20 & 1 & 1 \\
\hline Jmw & Wm-11 & 137 & 22 & 23 & 26 & 0 & 0 & 0 & 0 & 0 & 0 & 0 & 0 & 0 & 0 & 90 & 1 & 0 & 0 \\
\hline $\mathrm{Jmw}$ & Wm-12 & 103 & 25 & 33 & 37 & 0 & 0 & 0 & 0 & 0 & 0 & 99 & 0 & 0 & 0 & 0 & 0 & 1 & 0 \\
\hline $\mathrm{Jmr}$ & Wm-13 & 165 & 30 & 20 & 24 & 0 & 0 & 1 & 0 & 0 & 0 & 0 & 4 & 4 & 2 & 0 & 7 & 0 & 43 \\
\hline \multicolumn{20}{|c|}{ Laguna } \\
\hline Jmj & $\mathrm{Lg}-4$ & 194 & 13 & 1 & 15 & 0 & 0 & 0 & 0 & 0 & 0 & 0 & 20 & 0 & 0 & 0 & 12 & 0 & 45 \\
\hline $\mathrm{Jmj}$ & $\mathrm{Lg}-5$ & 160 & 26 & 5 & 23 & 0 & 0 & 0 & 0 & 0 & 0 & 0 & 0 & 0 & 0 & 0 & 28 & 4 & 54 \\
\hline $\mathrm{Jmj}$ & $\mathrm{Lg}-6$ & 160 & 31 & 2 & 26 & 0 & 0 & 0 & 0 & 0 & 0 & 0 & 20 & 0 & 0 & 0 & 22 & 2 & 37 \\
\hline $\mathrm{Jmb}$ & Lg-7 & 185 & 18 & 11 & 18 & 0 & 0 & 0 & 0 & 0 & 0 & 0 & 17 & 0 & 0 & 0 & 25 & 0 & 26 \\
\hline $\mathrm{Jmb}$ & Lg-8 & 149 & 19 & 14 & 23 & 0 & 0 & 0 & 0 & 0 & 0 & 0 & 34 & 2 & 4 & 0 & 15 & 0 & 40 \\
\hline $\mathrm{Jmw}$ & Lg-9 & 151 & 16 & 6 & 21 & 0 & 0 & 1 & 36 & 0 & 0 & 57 & 6 & 0 & 0 & 0 & 4 & 0 & 2 \\
\hline $\mathrm{Jmw}$ & $\mathrm{Lg}-10$ & 140 & 3 & 4 & 58 & 0 & 0 & 0 & 93 & 0 & 0 & 0 & 0 & 1 & 0 & 0 & 0 & 0 & 2 \\
\hline $\mathrm{Jmw}$ & $\mathrm{Lg}-11$ & 143 & 11 & 1 & 19 & 0 & 0 & 0 & 126 & 0 & 0 & 0 & 0 & 0 & 0 & 0 & 0 & 0 & 0 \\
\hline $\mathrm{Jmr}$ & Lg-13 & 178 & 15 & 5 & 17 & 0 & 0 & 0 & 85 & 0 & 0 & 0 & 0 & 0 & 0 & 0 & 0 & 0 & 0 \\
\hline \multicolumn{20}{|c|}{ Encinal Canyon } \\
\hline Kdec & Ec-1 & 172 & 12 & 0 & 21 & 0 & 0 & 0 & 38 & 0 & 0 & 10 & 29 & 0 & 0 & 0 & 0 & 0 & 28 \\
\hline Kdec & Ec-2 & 177 & 18 & 0 & 38 & 0 & 0 & 0 & 1 & 0 & 0 & 0 & 19 & 0 & 0 & 0 & 26 & 0 & 21 \\
\hline Kdec & Ec-3 & 177 & 21 & 0 & 17 & 0 & 0 & 0 & 0 & 0 & 0 & 0 & 43 & 0 & 0 & 1 & 25 & 0 & 16 \\
\hline Kdec & $\mathrm{Ec}-4$ & 207 & 18 & 0 & 19 & 0 & 0 & 0 & 0 & 0 & 0 & 0 & 4 & 0 & 0 & 0 & 49 & 0 & 3 \\
\hline \multicolumn{20}{|c|}{ Galisteo Dam } \\
\hline $\mathrm{Kbc}$ & Gd-1 & 207 & 0 & 0 & 30 & 0 & 0 & 0 & 0 & 0 & 0 & 0 & 0 & 0 & 0 & $\theta$ & 43 & 0 & 3 \\
\hline $\mathrm{Jmb}$ & Gd-5 & 98 & 56 & 0 & 19 & 0 & 0 & 0 & 5 & 0 & 0 & 0 & 0 & 0 & 0 & 110 & 12 & 0 & 0 \\
\hline $\mathrm{Jmu}$ & Gd-6a & 134 & 22 & 27 & 19 & 0 & 0 & 0 & 87 & 0 & 0 & 0 & 8 & 0 & 0 & 0 & 3 & 0 & 0 \\
\hline $\mathrm{Jmu}$ & Gd-8 & 153 & 18 & 10 & 15 & 0 & 0 & 0 & 0 & 0 & 0 & 0 & 59 & 0 & 0 & 0 & 11 & 22 & 12 \\
\hline
\end{tabular}


Table 1. Continued

\begin{tabular}{|c|c|c|c|c|c|c|c|c|c|c|c|c|c|c|c|c|c|c|c|}
\hline $\begin{array}{l}\text { Strat } \\
\text { unit }\end{array}$ & $\begin{array}{c}\text { Sample } \\
\text { number }\end{array}$ & Qtz & Kspar & Plag & $\begin{array}{l}\text { Rock } \\
\text { frag }\end{array}$ & BiotiteN & Musc & $\begin{array}{c}\text { Heav } \\
\text { min }\end{array}$ & Calcite & Anhy & Barite & Zeol & $\begin{array}{l}\text { Qtz } \\
\text { ovgr }\end{array}$ & $\begin{array}{c}\text { Kspar } \\
\text { ovgr }\end{array}$ & $\begin{array}{l}\text { Albite } \\
\text { ovgr }\end{array}$ & Chal & \multicolumn{3}{|c|}{ ClayHematite Voic } \\
\hline \multicolumn{20}{|c|}{ Ghost Ranch } \\
\hline Kdec & Gr-1 & 207 & 1 & 0 & 8 & 0 & 0 & 0 & 0 & 0 & 0 & 0 & 38 & 0 & 0 & 15 & 6 & 1 & 24 \\
\hline $\mathrm{Kbc}$ & $\mathrm{Gr}-4$ & 158 & 8 & 1 & 31 & 0 & 0 & 0 & 11 & $\mathbf{0}$ & 0 & 0 & 2 & 0 & 0 & 73 & 6 & 7 & 3 \\
\hline $\mathrm{Jmb}$ & Gr-5 & 150 & 28 & 1 & 18 & 1 & 0 & 0 & 0 & 0 & 0 & 0 & 0 & 0 & 0 & 0 & 90 & 0 & 10 \\
\hline \multicolumn{20}{|c|}{ Dennison-Bunn } \\
\hline Kdoc & Db-Kd & 211 & 14 & 0 & 6 & 0 & 0 & 0 & 0 & 0 & 0 & 0 & 19 & 0 & 0 & 0 & 27 & 0 & 23 \\
\hline $\mathrm{Jmj}$ & $\mathrm{Db}-1$ & 187 & 19 & 0 & 20 & 0 & 0 & 0 & 0 & 0 & 0 & 0 & 48 & 2 & 0 & 0 & 7 & 0 & 17 \\
\hline $\mathrm{Jmj}$ & $\mathrm{Db}-2$ & 238 & 13 & 0 & 6 & 0 & 0 & 0 & 0 & 0 & 0 & 0 & 0 & 0 & 0 & 0 & 1 & 1 & 41 \\
\hline $\mathrm{Jmb}$ & Db-5 & 174 & 32 & 0 & 26 & 0 & 0 & 0 & 0 & 0 & 0 & 0 & 0 & 0 & 0 & 0 & 24 & 0 & 44 \\
\hline $\mathrm{Jmb}$ & Db-6 & 182 & 20 & 1 & 4 & 0 & 0 & 0 & 0 & 0 & 0 & 0 & 1 & 12 & 0 & 0 & 21 & 1 & 56 \\
\hline $\mathrm{Jmw}$ & $\mathrm{Db}-8$ & 191 & 20 & 4 & 18 & 0 & 0 & 0 & 0 & 0 & 0 & 0 & 24 & 11 & 0 & 0 & 7 & 0 & 25 \\
\hline $\mathrm{Jmw}$ & Db-9 & 190 & 16 & 1 & 16 & 0 & 0 & 0 & 0 & 0 & 0 & 0 & 15 & 13 & 0 & 0 & 28 & 0 & 21 \\
\hline Jmw & Db-10 & 147 & 36 & 2 & 40 & 0 & 0 & 0 & 0 & 0 & 0 & 0 & 15 & 10 & 0 & 1 & 19 & 0 & 30 \\
\hline Jmw & $\mathrm{Db}-11$ & 160 & 33 & 9 & 25 & 1 & 1 & 1 & 13 & 0 & 0 & 0 & 5 & 5 & 0 & 0 & 18 & 2 & 25 \\
\hline $\mathrm{Jmr}$ & Db-12 & 127 & 27 & 6 & 35 & 0 & 0 & 3 & 97 & 0 & 0 & 0 & 0 & 0 & 0 & 0 & 5 & 0 & 0 \\
\hline $\mathrm{Jmr}$ & Db-14 & 163 & 38 & 6 & 15 & 1 & 0 & 0 & 1 & 0 & 1 & 0 & 0 & 0 & 0 & 0 & 12 & 1 & 62 \\
\hline \multicolumn{20}{|c|}{ Beclabito dome } \\
\hline Jmsw & $\mathrm{Bd}-4$ & 207 & 12 & 3 & 13 & 0 & 0 & 1 & 24 & 2 & 1 & 0 & 16 & 0 & 0 & 0 & 7 & 0 & 13 \\
\hline Jmsw & $\mathrm{Bd}-5$ & 125 & 9 & 1 & 14 & 0 & 0 & 0 & 29 & 0 & 0 & 0 & 27 & 0 & 0 & 0 & 3 & 0 & 22 \\
\hline Jmsw & Bd-6 & 181 & 10 & 10 & 17 & 0 & 0 & 0 & 17 & 0 & 0 & 0 & 20 & 0 & 0 & 0 & 3 & 0 & 42 \\
\hline $\mathrm{Jmw}$ & $\mathrm{Bd}-8$ & 167 & 12 & 15 & 20 & 0 & 0 & 0 & 1 & 0 & 0 & 0 & 47 & 1 & 9 & 0 & 23 & 0 & 5 \\
\hline Jmw & Bd-11 & 206 & 13 & 18 & 15 & 0 & 0 & 0 & 0 & 0 & 0 & 6 & 3 & 0 & 2 & 0 & 11 & 0 & 26 \\
\hline $\mathrm{Jmw}$ & $\mathrm{Bd}-13$ & 187 & 17 & 14 & 10 & 0 & 1 & 0 & 6 & 0 & 0 & 6 & 14 & 0 & 0 & 0 & 25 & 0 & 20 \\
\hline $\mathrm{Jmb}$ & Bd-18 & 113 & 3 & 11 & 12 & 0 & 0 & 0 & 1 & 0 & 0 & 58 & 8 & 0 & 0 & 88 & 0 & 0 & 0 \\
\hline Jmb & $\mathrm{Bd}-22$ & 158 & 2 & 8 & 23 & 0 & 0 & 0 & 2 & 0 & 0 & 1 & 0 & 0 & 1 & 0 & 3 & 0 & 1 \\
\hline \multicolumn{20}{|c|}{ Oak Springs } \\
\hline Jmsw & Os-17 & 173 & 21 & 4 & 10 & 0 & 0 & 2 & 39 & 1 & 0 & 25 & 0 & 0 & 0 & 0 & 0 & 0 & 25 \\
\hline $\mathrm{Jmsw}$ & Os-20 & 185 & 26 & 7 & 22 & 0 & 0 & 1 & 2 & 0 & 0 & 0 & 1 & 0 & 0 & 0 & 19 & 0 & 37 \\
\hline Jmsw & Os-22 & 176 & 25 & 14 & 22 & 0 & 0 & 0 & 6 & 0 & 0 & 0 & 12 & 0 & 0 & 0 & 0 & 0 & 45 \\
\hline $\mathrm{J} \mathrm{mr}$ & Os-25 & 169 & 29 & 13 & 6 & 0 & 0 & 3 & 0 & 0 & 0 & 0 & 0 & 0 & 0 & 0 & 3 & 0 & 77 \\
\hline $\mathrm{Jmr}$ & Os-26 & 174 & 26 & 14 & 13 & 0 & 0 & 1 & 0 & 0 & 0 & 0 & 1 & 0 & 0 & 0 & 6 & 0 & 56 \\
\hline $\mathrm{Jmr}$ & Os-30 & 137 & 29 & 15 & 23 & 0 & 1 & 1 & 74 & 0 & 0 & 0 & 0 & 0 & 0 & 0 & 11 & 1 & 8 \\
\hline Jmw & Os-32 & 186 & 19 & 9 & 29 & 0 & 0 & 0 & 11 & 0 & 0 & 0 & 0 & 0 & 0 & 0 & 13 & 0 & 33 \\
\hline $\mathrm{Jmw}$ & Os-34 & 218 & 15 & 4 & 18 & 0 & 0 & 0 & 2 & 0 & 0 & 0 & 12 & 0 & 0 & 0 & 4 & 0 & 27 \\
\hline $\mathrm{Jmw}$ & Os-38 & 207 & 23 & 4 & 23 & 0 & 0 & 0 & 2 & 0 & 0 & 0 & 4 & 0 & 0 & 0 & 18 & 0 & 19 \\
\hline$J_{m} w$ & Os -42 & 194 & 12 & 7 & 15 & 0 & 0 & 0 & 0 & 0 & 0 & 0 & 26 & 2 & 0 & 0 & 6 & 0 & 30 \\
\hline $\mathrm{Jmb}$ & Os -43 & 136 & 15 & 9 & 32 & 0 & 0 & 0 & 57 & 0 & 1 & 3 & 29 & 2 & 0 & 0 & 11 & 4 & 0 \\
\hline $\mathrm{Jmb}$ & Os-50 & 152 & 13 & 12 & 29 & 1 & 0 & 0 & 0 & 0 & 0 & 0 & 0 & 0 & 1 & 79 & 13 & 0 & 0 \\
\hline
\end{tabular}

Member. Micritic fragments were noted at the Dennison-Bunn and Oak Springs sections, and micritic oolites occur at Laguna. Most rock fragments are chert, other fine-grained sedimentary rocks such as shale and siltstone, volcanic (felsite), and metamorphic (stretched polycrystalline quartz, chlorite) types. The most notable aspect of framework mineralogy is the (rare) appearance of detrital plagioclase grains rimmed with potassium feldspar (anti-rapakivi texture) near the top of the Recapture Member. (See discussion on Westwater Canyon Member in next section.) Some plagioclase is untwinned; twinned varieties are dominantly albite and minor pericline and carlsbad. Low angles between twin planes and cleavage traces and the thinness of twin laminae suggest that plagioclase compositions range from albite to andesine.

\section{Westwater Canyon Member}

Sandstones of the Westwater Canyon Member are principally subarkoses and lithic arkoses (fig. 2C) characterized by large amounts of volcanic material including sanidine and volcanic rock fragments. The dominant fragments are fine-grained felsic volcanic rocks containing rare quartz or feldspar phenocrysts (fig. 3). Other rock fragments are (in decreasing order) polycrystalline quartz (metamorphic and plutonic igneous), chert, and chlorite. Rare plutonic fragments are very fine grained and have a "granitic" composition. Relict shard textures that were preserved by early smectite, calcite, or zeolite cements (fig. 4) indicate that volcanic ash composed much of the original matrix of these sandstones. 


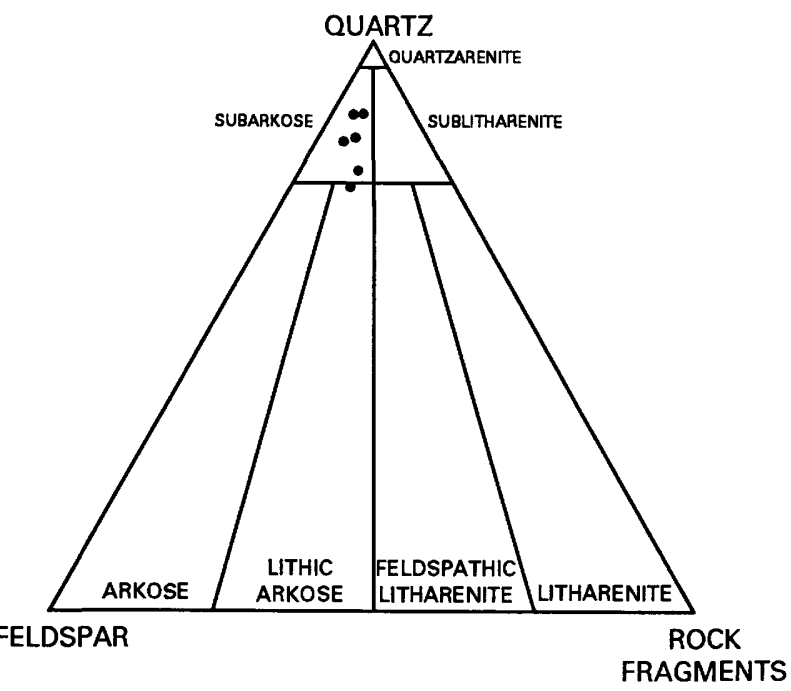

$c$

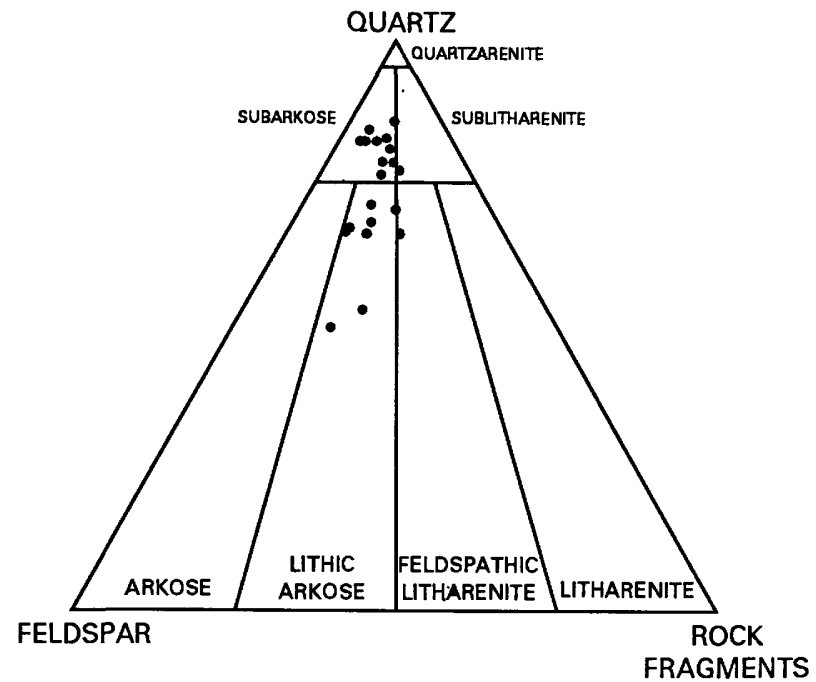

$B$
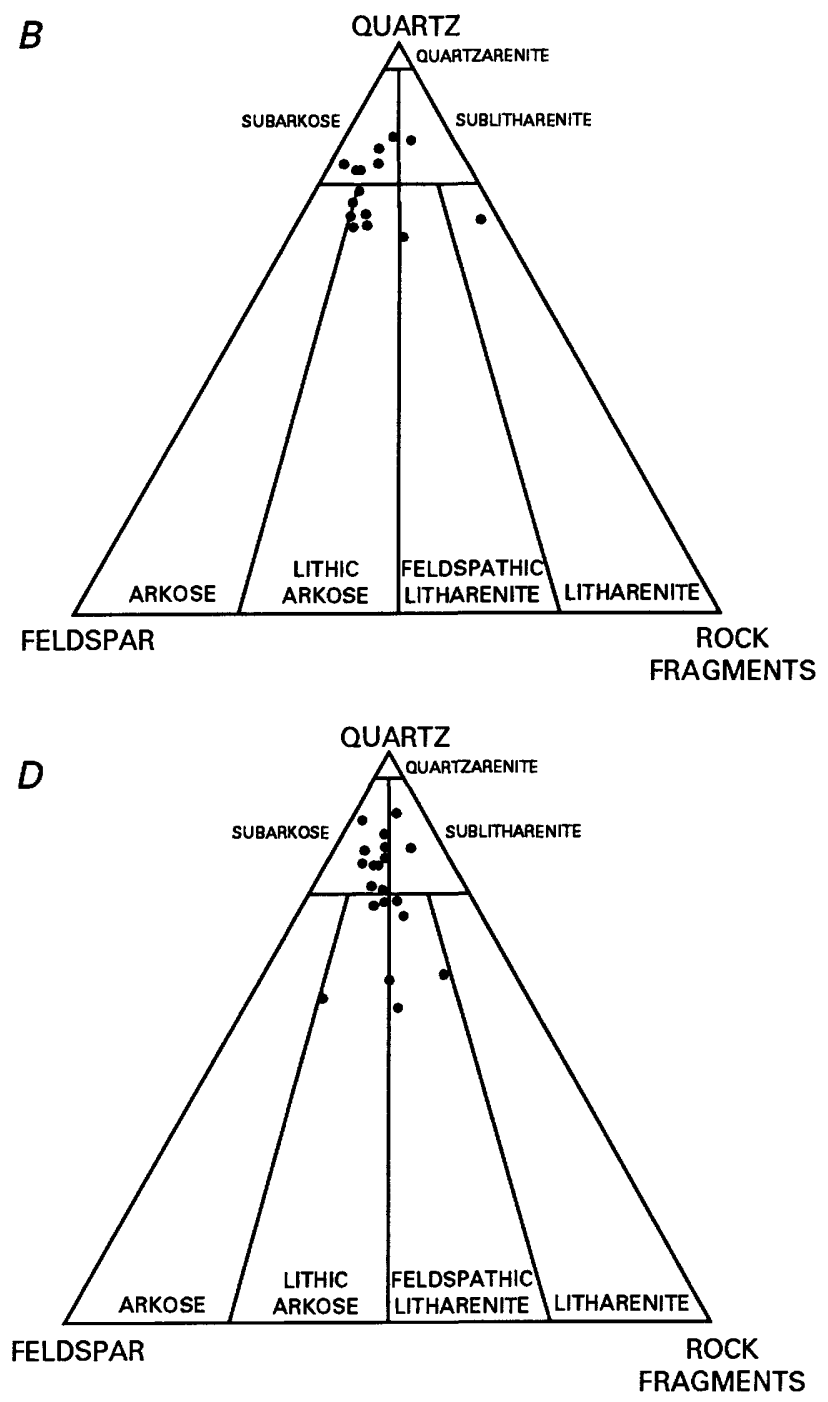

Figure 2. Classification of sandstones in the Morrison Formation. $A$, Salt Wash Member; $B$, Recapture Member; $C$, Westwater Canyon Member; $D$, Brushy Basin Member. Classification scheme after Folk (1974).

Plagioclase grains having potassium feldspar rims (for example, anti-rapakivi texture) occur throughout the Westwater Canyon Member (fig. $5 A$ ) but are most common in medium-grained sandstones of the middle to upper part of the Westwater Canyon Member. The only place that these grains do not occur is in the Morrison Formation at Durango, where most feldspars have been completely albitized. Locally, the plagioclase core has been partly to totally dissolved such that only a rim of potassium feldspar enclosing a void remains (fig. $5 B$ ). Although some potassium feldspar-rimmed grains display overgrowths (fig. $5 C$ ), most potassium feldspar extends inward from the rims of plagioclase-cored grains without overgrowth development. Remnants of plagioclase cores are commonly albitized as indicated by high birefringence (fig. $5 D$ ) and electron microprobe analyses showing 99 mole percent albite (Hansley, 1986b). Associated mixed-layer I/S may or may not be illitized.
In the Grants uranium region, the presence of hollow potassic sanidine rims without plagioclase cores led Austin $(1963,1980)$ to conclude that these distinctive potassium feldspar rims were skeletal detrital sanidine grains. Subsequently, these rims were reinterpreted to be metasomatic replacement of plagioclase by potassium feldspar and (or) authigenic potassium feldspar overgrowths that had precipitated on detrital plagioclase grains; rims became hollow when the plagioclase dissolved (Hansley, 1986b). This conclusion was based on detailed quantitative electron microprobe analyses, observations that the potassium feldspar rim was composed of many euhedral, micron-size authigenic potassium feldspar crystals having different optical orientations, and the presence in the sample suite of the total spectrum from a detrital plagioclase having a potassium feldspar rim to a potassium feldspar rim enclosing a void (Hansley, 1986b). The potassium feld- 


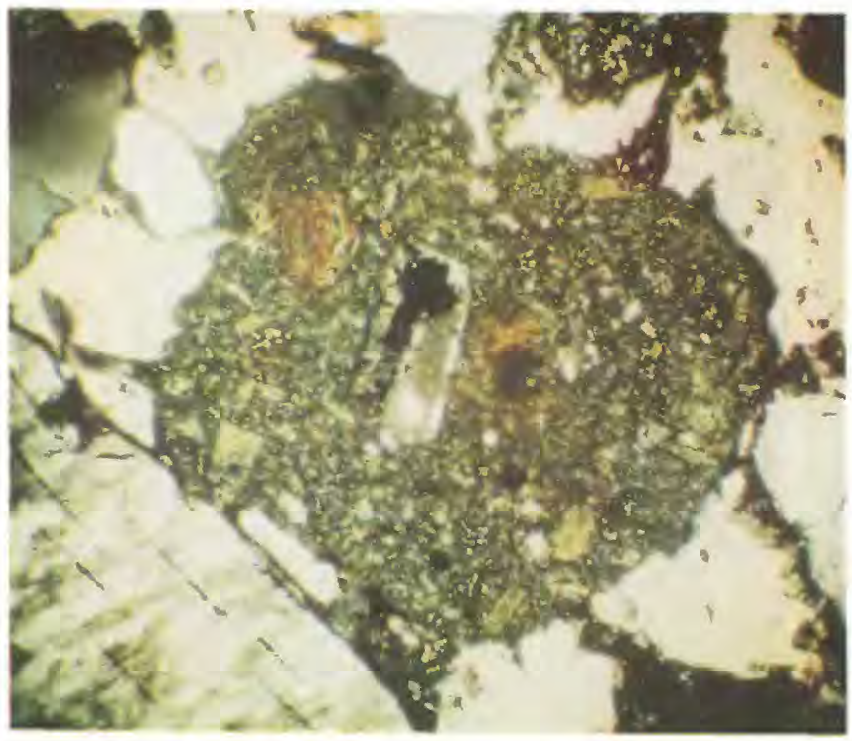

Figure 3. Photomicrograph showing felsic volcanic rock fragment in the Westwater Canyon Member at Oak Springs. Plane-polarized light; length of field, $0.2 \mathrm{~mm}$.

spar rims did not exhibit cathodoluminescence and are almost pure potassic sanidine containing 16.27 percent $\mathrm{K}_{2} \mathrm{O}, 0.15$ percent $\mathrm{Na}_{2} \mathrm{O}$, and 0.003 percent $\mathrm{CaO}$ (Hansley, 1986b); thus, they formed at low temperatures (Kastner, 1971). What was not considered in either Hansley's or Kastner's study was the possibility that the potassium feldspar rims are in part detrital.

Petrographic observations made during the present study suggest that plagioclase grains having anti-rapakivi textures were inherited from the source area: (1) development of potassium feldspar rims even at grain contacts, (2) potassium feldspar-rimmed plagioclase in sandstones cemented by early quartz and zeolite cements, and (3) lack of potassium feldspar overgrowth development on adjacent detrital potassium feldspars. The abrupt appearance of these distinctive grains in the upper part of the Recapture Member suggests that intermediate volcanic rocks were unroofed in the source area or, alternatively, that a new source area began to feed sediments into the San Juan basin. The appearance of these grains coincides with the appearance of other types of volcanic material such as sanidine and euhedral zircons. Thick sequences of Mesozoic rhyolitic and dacitic volcanic rocks in southern Arizona (Cooley and Davidson, 1963) were potential sources for these grains as well as for the potassic volcanic rock fragments. An orogenic belt to the west of the Colorado Plateau may have been another source of andesitic material. Plagioclase grains having anti-rapakivi textures are common in dacites and andesites (Williams and others, 1954).
Most fluvial sandstones of the Brushy Basin and Jackpile Sandstone Members are subarkoses (fig. $2 D$ ) having compositions very similar to those of sandstones in the Westwater Canyon Member. Moench and Schlee (1961) reported 80-95 percent quartz and 1-19 percent feldspar in sandstones of the Jackpile, but Adams and others (1978) reported only 60-79 percent quartz and 13 percent feldspar. Sandstones of the Brushy Basin and Jackpile Sandstone Members contain fewer rock fragments owing to their generally smaller grain size. In some Brushy Basin samples, early silica and zeolite cements apparently protected feldspars from dissolution resulting in a higher feldspar content than in other sandstones of the Morrison Formation. Potassium feldspar-rimmed plagioclases were noted only in coarser sandstones of the lower part of the Brushy Basin Member.

\section{Cretaceous sandstones}

Most sandstones of the Encinal Canyon Member of the Dakota Sandstone are sublitharenites; sandstones containing more feldspar are subarkoses. Major constituents are quartz, potassium feldspar, and silicic rock fragments such as chert and quartzite. Unlike sandstones of the Jackpile, sandstones of the Encinal Canyon contain no plagioclase. This absence may be the result of diagenesis, or it may reflect an original lack of plagioclase; too few samples were examined to be able to determine the reason for this absence.

\section{DIAGENESIS}

\section{Heavy Minerals}

The results of previous studies (Hansley, 1986a) and of the present study indicate that of the common heavy-mineral species in the Morrison, staurolite and garnet were the most affected by intrastratal solution, and zircon, tourmaline, and apatite show virtually no effects of diagenetic alteration. In the USGS cores, staurolite and garnet were deeply etched and possibly totally dissolved locally by diagenetic processes (Hansley, 1986a). In the outcrop samples of this study, however, both are preserved (not etched). Deeply etched garnets (fig. 6) texturally similar to those in the USGS cores (Hansley, 1986a, 1987) were found only in the Salt Wash Member in the northwestern part of the basin (fig. 7) in sandstones stratigraphically equivalent to ore-bearing sandstones. At Durango Hospital, the lack of garnets may be due to intrastratal dissolution. In other outcrop sections, many garnets display minor surface etching, but 

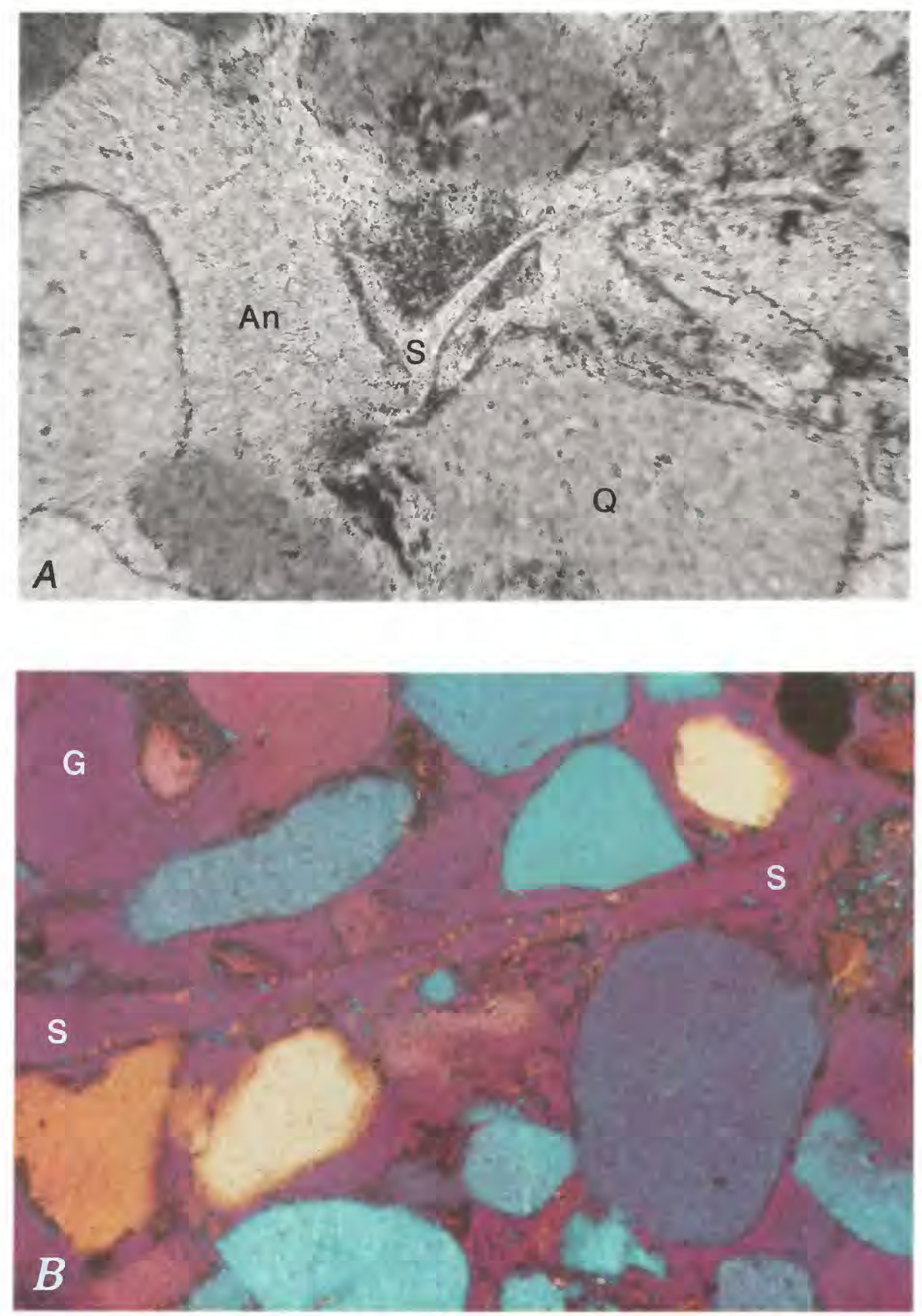

Figure 4. Photomicrographs showing vitric textures preserved in analcimecemented sandstone of the Brushy Basin Member from Senorita Canyon (planepolarized light). $A$, Clinoptilolite- and smectite-rimmed shard (S) infilled with analcime (An). Analcime also fills voids. $Q$, detrital quartz grain. Length of field, $0.6 \mathrm{~mm}$. $B$, Shard (S) infilled by analcime (S's are at each end of the shard); shard is outlined by micron-size yellow clinoptilolite grains. Analcime-filled pores are reddish purple due to insertion of gypsum plate. Note grain $(G)$ that has been replaced entirely by analcime and preponderance of floating grains. Length of field, $0.8 \mathrm{~mm}$.

most are unetched. The Encinal Canyon Member does not contain any garnets, probably as a result of attrition during transport or during the reworking of older sediments. Unfortunately, the sample number (13) is not large enough to ascertain whether this is truly a major distinction between sandstones of the Encinal Canyon and the Jackpile, which are otherwise very similar in composition.

Several varieties of authigenic heavy minerals including leucoxene, anatase, and pyrite are common in 

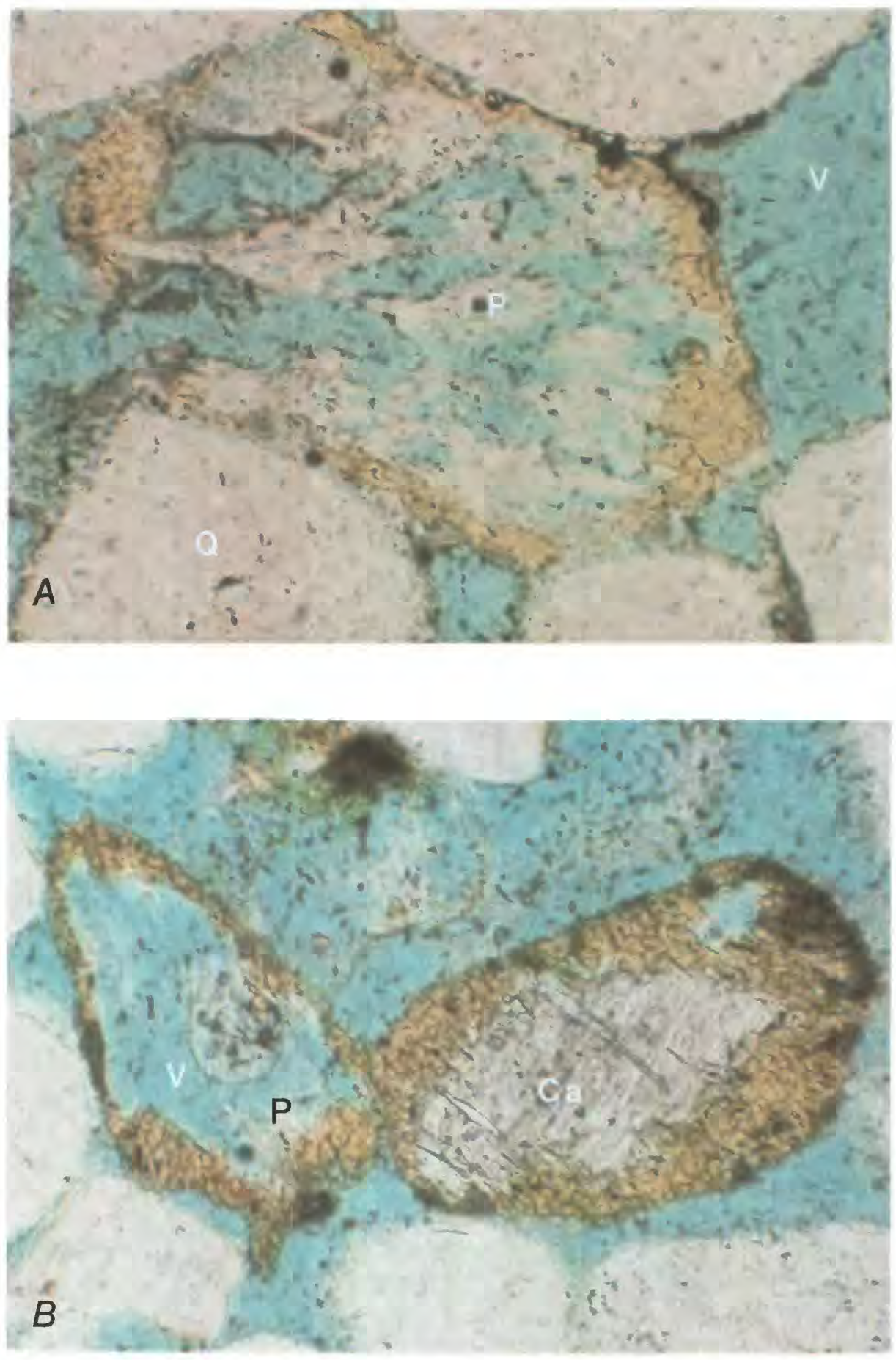

Figure 5 (above and following page). Photomicrographs showing anti-rapakivi textures of detrital plagioclase grains. Note inward extension of potassium feldspar from detrital rims. Plagioclase grains are in sandstone of the Westwater Canyon Member at Beclabito dome. A, Partly dissolved plagioclase grain $(\mathrm{P})$ rimmed by potassium feldspar overgrowth (stained yellow green by potassium cobaltinitrate). V, void (blue); Q, quartz. Planepolarized light; length of field, $0.4 \mathrm{~mm}$. B, Two potassium feldspar overgrowth rims (yellow) that remain after dissolution of plagioclase cores: one rim contains plagioclase remnants $(P)$ in the dissolution void $(\mathrm{M})$; the other is filled in with calcite (Ca). Plane-polarized light; length of field, $0.7 \mathrm{~mm}$. C, Partly dissolved, albitized detrital plagioclase grain with potassium feldspar rim (Ko, stained greenish yellow) near detrital potassium feldspar grains $(K)$ that do not have overgrowths. Note quartz overgrowth $(\mathrm{Q})$ ) on detrital quartz grain (Q). Crossed polars; length of field, $0.8 \mathrm{~mm}$. 


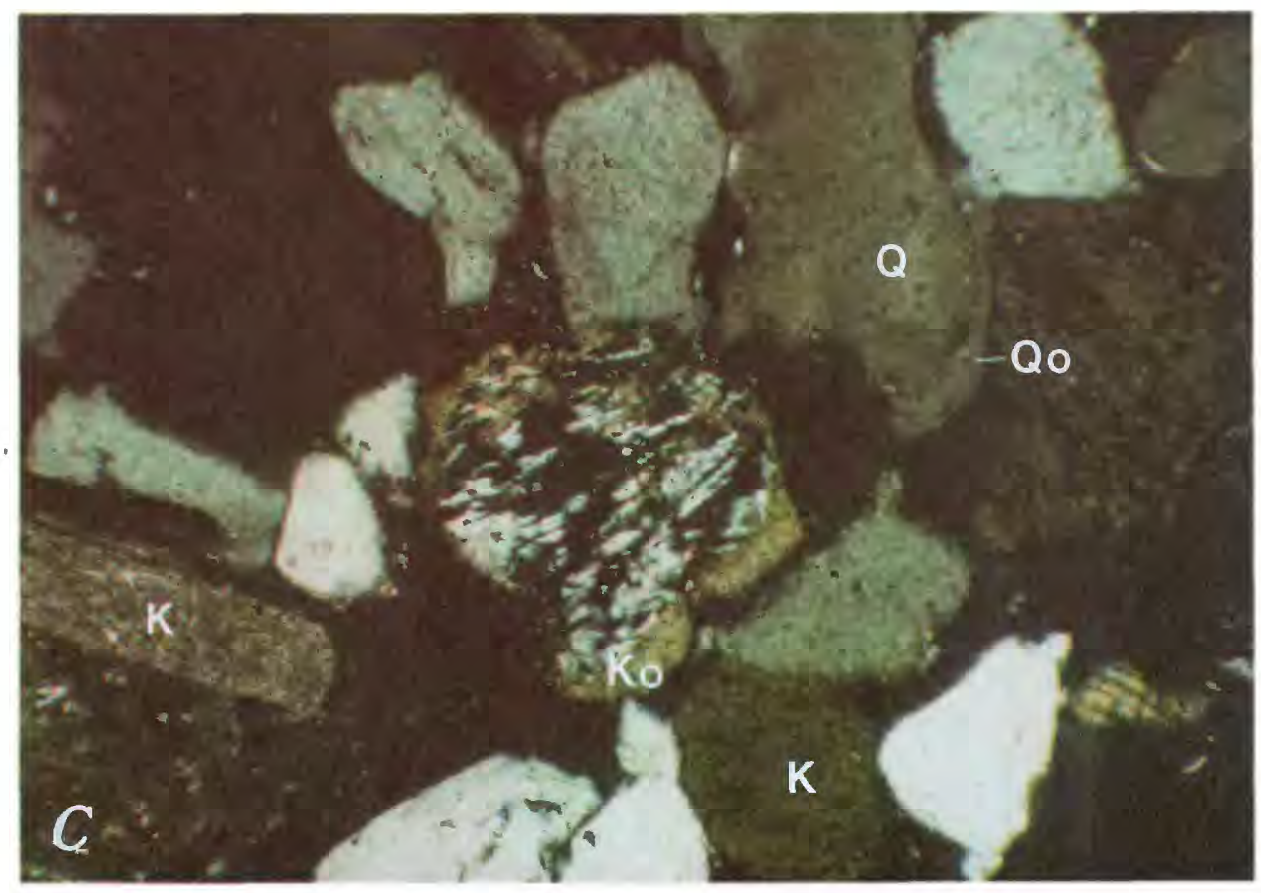

the Morrison Formation. Pyrite is locally abundant as a cement and as euhedral grains in the Westwater Canyon Member associated with organic matter and uranium enrichment in cores; it is rare in outcrop sections. Euhedral titanium dioxide minerals such as anatase are present in most heavy-mineral grain mounts and are thought to be alteration products of detrital irontitanium oxide minerals. Comprehensive studies of irontitanium oxide minerals and their alteration products in the Morrison Formation in the San Juan basin were conducted by Adams and others (1974) and Reynolds and others (1986).

\section{General Sandstone Diagenesis}

The distributions of authigenic minerals in all members reveal distinct trends across the basin highlighted by an increase in the complexity of alterations to the north. The regional distributions of major authigenic clay minerals in sandstones of the Recapture, Westwater Canyon, and Brushy Basin Members are shown in figure 8. Scanning electron microscope observations of (delicate) textures and of trends in expandability of mixed-layer clay minerals in the Morrison Formation indicate that these clays are authigenic. (See table 2 for point counts of authigenic phases in thin section.) Diagenesis has severely altered frameworkmineral assemblages around the basin, and the inferred paragenesis of major postdepositional alterations is shown in figure 9.

\section{Salt Wash Member}

Lower sandstones of the Salt Wash Member are sporadically well cemented with quartz overgrowths and calcite. Upper sandstones are characterized by dissolution as evidenced by skeletal plagioclase, corroded quartz grains, moderately etched garnets, and remnant calcite cement. Small uranium-vanadium claims occur in the upper part of the Salt Wash near Oak Springs.

The clay mineralogy of the Salt Wash Member was determined only at Beclabito dome where the dominant authigenic clay mineral is chlorite. The 002 and 004 peaks do not have an appreciably greater intensity than

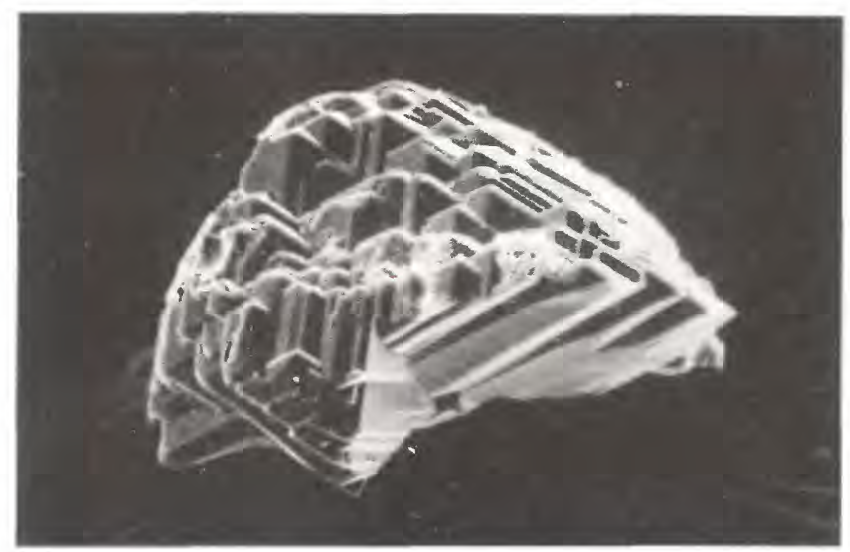

Figure 6. Scanning electron micrograph showing deeply etched garnet from the Morrison Formation. Length of field, $0.30 \mathrm{~mm}$. Sample is from USGS core 7 . 


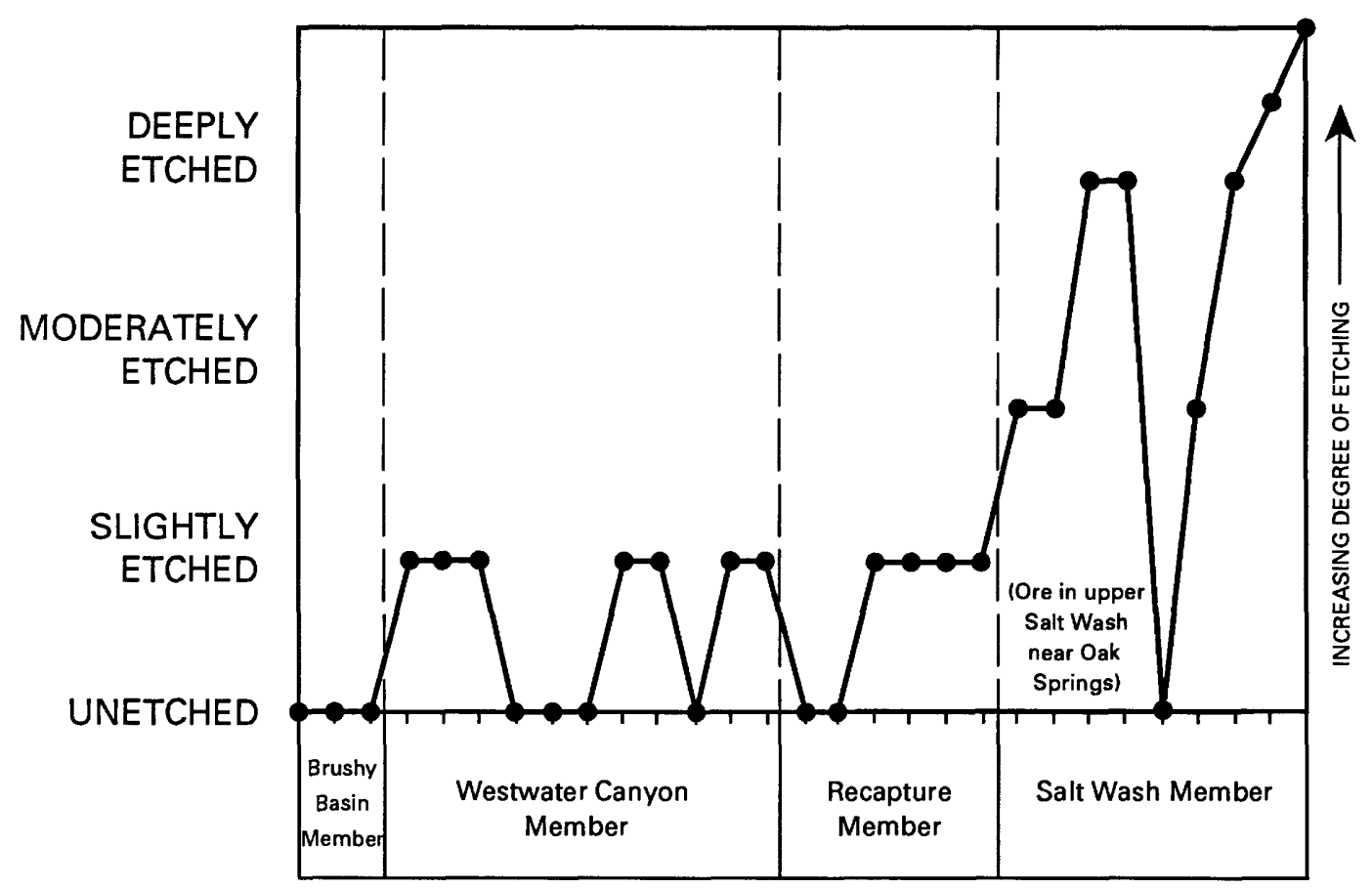

Figure 7. Occurrence of garnet textures in the Morrison Formation at Oak Springs. Note correlation between deeply etched garnets and uranium ore. One sandstone in the middle part of the Salt Wash Member containing unetched garnets is fine grained; the other sandstones are medium grained.

than the 001 and 003 peaks (fig. 10), indicating that the chlorite is not ferroan (Brown and Brindley, 1980). Both minor ordered I/S having 70-90 percent illite layers $(0.7-0.9 \mathrm{I})$ and kaolinite are present in most samples.

\section{Recapture Member}

In general, sandstones in the Recapture Member are characterized by abundant (early) calcite cement, which commonly fills as much as 30 percent of the primary pores; little additional alteration is present except for minor anhydrite and barite cement. Where dissolution of calcite has taken place, skeletal plagioclase is present.

Diagenesis is most advanced in the eastern part of the study area at Galisteo Dam where the Recapture equivalent is present and at the Durango Hospital section. At Galisteo Dam, the lower sandstones in the Morrison (Recapture equivalent?) contain abundant quartz overgrowths and (or) minor albite overgrowths. Hematite cement coats the overgrowths. In the northernmost part of the study area at the Durango Hospital section, the Recapture, which lies directly under the Brushy Basin, contains abundant quartz and albite overgrowths (for example, even on detrital potassium feldspar) and calcite, and locally anhydrite, barite, and hematite cements. Intermittent sericitization of plagioclase grains suggests that sericitization occurred before deposition.
Clay-mineral trends in the Recapture parallel the trends of other authigenic minerals in that more advanced diagenetic phases occur in the northern part of the basin. At Beclabito dome, chlorite and ordered I/S ( $>0.75 \mathrm{I}$ ) are dominant, and kaolinite is a minor phase. At the northernmost section of this study, Durango Hospital, the Recapture contains major I/S ( $>0.9$ I) and minor kaolinite. In contrast, along the eastern side of the basin from Capulin Peak south to White Mesa, clays are dominantly kaolinite and expandable I/S $(<0.1 \mathrm{I})$. In the USGS cores from the southern part of the basin, authigenic clays in the Recapture are also dominantly smectite (Whitney, 1986).

\section{Westwater Canyon Member}

Diagenesis in sandstones of the Westwater Canyon Member is characterized by a general upward increase in amount of diagenetic alteration in outcrops and in cores and by an increase in intensity of alteration to the north.

In the northwestern part of the basin at Beclabito dome, sandstones of the Westwater Canyon Member contain abundant quartz and albite overgrowths and minor potassium feldspar overgrowths. Tabular clinoptilolite crystals ( $>50 \mu \mathrm{m}$ ) partly fill pores (fig. 11) and may be intergrown with authigenic quartz (fig. 12) in upper sandstones. Analcime occurs locally as a cement or as an infilling in skeletal plagioclase grains (fig. 13A), and 
Table 2. Results of $X$-ray diffraction analyses of the $<2-\mu \mathrm{m}$ fraction of selected sandstones $[+++, 3,000$ counts; $++,>2,000$ counts; $+>500<2,000$ counts; Trace, $<500$ counts; leaders (---) indicate none detected. $<0.1 \mathrm{I}$ indicates $<10$ percent illite in illite/smectite]

\begin{tabular}{|c|c|c|c|c|}
\hline Stratigraphic unit & Sample No. & Chlorite & Illite/smectite & Kaolinite \\
\hline \multicolumn{5}{|c|}{ Beclabito Dome } \\
\hline Burro Canyon Formation & $81-B d-37$ & $-\cdots$ & $+++(<0.3 \mathrm{I})$ & + \\
\hline Dakota Sandstone & -.- & $\cdots$ & --- & ++ \\
\hline Brushy Basin 1 & $81-B d-36$ & $\ldots$ & Trace $(0.8 \mathrm{I},>0.9 \mathrm{I})$ & + \\
\hline Do. & $81-B d-35$ & Trace & Trace $(0.8 \mathrm{I}, 0.65 \mathrm{I})$ & Trace \\
\hline Do. & $81-B d-34$ & Trace & Trace & Trace \\
\hline Do. & 81-Bd-33 & + & Trace $(0.75 \mathrm{I}, 0.5 \mathrm{I})$ & + \\
\hline & 81-Bd-32 & + & Trace $(0.5 \mathrm{I} 0.8 \mathrm{I})$ & + \\
\hline Westwater Canyon 1 & 81-Bd-31 & Trace & Trace $(0.7 \mathrm{I},<0.6 \mathrm{I})$ & Trace \\
\hline Do. & 81-Bd-30 & -- & Trace (2 phases) & Trace \\
\hline Do. & $81-B d-29$ & Trace & $+(0.7 \mathrm{I})$ & + \\
\hline Do. & $81-B d-28$ & + & Trace & \\
\hline Do. & $81-B d-26$ & Trace & Trace & Trace \\
\hline Do. & $81-B d-25$ & Trace & Trace & Trace \\
\hline Recapture $^{1}$ & $81-B d-24$ & + & $+(>0.6 \mathrm{I})$ & Trace \\
\hline Do. & $81-B d-23$ & + & Trace $(>0.6 \mathrm{I})$ & \\
\hline Do. & $81-B d-22$ & + & Trace $(0.7 \mathrm{I})$ & Trace \\
\hline Do. & $81-B d-21$ & + & $+(0.7 \mathrm{I})$ & Trace \\
\hline Do. & $81-\mathrm{Bd}-20$ & Trace & Trace & Trace \\
\hline Salt Wash ${ }^{1}$ & $81-B d-19$ & ++ & Trace $(0.6 \mathrm{I}, 0.7 \mathrm{I})$ & $\cdots$ \\
\hline Do. & $81-B d-18$ & + & $+(>0.9 \mathrm{I})$ & + \\
\hline Do. & $81-B d-16$ & ++ & Trace $(>0.9 \mathrm{I})$ & -- \\
\hline Do. & $81-B d-15$ & + & $+(>0.8 \mathrm{I})$ & -- \\
\hline Do. & $81-B d-17$ & ++ & Trace $(>0.9 \mathrm{I})$ & --- \\
\hline Do. & $81-B d-14$ & + & $+(>0.8 \mathrm{I})$ & --- \\
\hline \multicolumn{5}{|c|}{ Sanostee Wash } \\
\hline Brushy Basin 1 & $85-S w-13$ & -- & $+(<0.1 \mathrm{I})$ & ++ \\
\hline Do. & $85-S w-12$ & --- & $+(<0.1 \mathrm{I})$ & \\
\hline Do. & $85-S w-11$ & --- & $+(<0.1 \mathrm{I})$ & Trace \\
\hline Westwater Canyon ${ }^{1}$ & 83-Sw-10 & --- & $+(<0.1 \mathrm{I})$ & Trace \\
\hline Do. & 83-Sw-7 & --- & $+(<0.1 \mathrm{I})$ & Trace \\
\hline Do. & $83-S w-5$ & + & $+(<0.2 \mathrm{I})$ & + \\
\hline Do. & $83-S w-2$ & + & $+(<0.2 \mathrm{I})$ & + \\
\hline Do. & 83-Sw-1 & + & $+(<0.2 \mathrm{I})$ & + \\
\hline \multicolumn{5}{|c|}{ Asaayi Lake } \\
\hline Westwater Canyon 1 & 83-Al-12 & Trace & Trace & ++ \\
\hline Do. & 83-Al-10 & Trace & Trace & ++ \\
\hline Do. & 83-Al-9 & + & $+(<0.1 \mathrm{I})$ & ++ \\
\hline Do. & 83-Al-7 & Trace & $+(<0.1 \mathrm{I})$ & ++ \\
\hline Do. & $83-\mathrm{Al}-3$ & + & -- & + \\
\hline Do. & 83-Al-2 & + & $+(<0.1 \mathrm{I})$ & ++ \\
\hline \multicolumn{5}{|c|}{ Toadlena } \\
\hline Westwater Canyon 1 & $83-\mathrm{Td}-10$ & + & + (smectite) & ++ \\
\hline Do. & 83-Td-8 & + & Trace (smectite) & ++ \\
\hline Do. & 83-Td-7 & Trace & Trace(smectite) & ++ \\
\hline Do. & 83-Td-3 & + & (smectite) & ++ \\
\hline Do. & 83-Td-1 & + & Trace (smectite) & ++ \\
\hline \multicolumn{5}{|c|}{ Ghost Ranch } \\
\hline Encinal Canyon ${ }^{2}$ & $86-\mathrm{Gr}-1$ & --- & -- & +++ \\
\hline Morrison Formation & $86-G r-6$ & --- & $++(<0.1 \mathrm{I})$ & Trace \\
\hline Do. & $86-\mathrm{Gr}-3$ & $\ldots$ & $+(>0.9 \mathrm{I})$ & ++ \\
\hline \multicolumn{5}{|c|}{ Laguna } \\
\hline Jackpile Sandstone ${ }^{1}$ & $86-\mathrm{Lg}-6$ & Trace & Trace $(>0.9 \mathrm{I})$ & +++ \\
\hline Do. & $86-\mathrm{Lg}-4$ & -- & $(<0.1 I)$ & ++ \\
\hline Do. & 86-Lg-5 & -- & $++(<0.1 \mathrm{I})$ & ++ \\
\hline
\end{tabular}


Table 2. Continued

\begin{tabular}{|c|c|c|c|c|}
\hline Stratigraphic unit & Sample No. & Chlorite & Illite/smectite & Kaolinite \\
\hline \multicolumn{5}{|c|}{ San Pablo Canyon } \\
\hline Westwater Canyon ${ }^{1}$ & $85-S p-5$ & $-\ldots$ & $\ldots$ & + \\
\hline \multicolumn{5}{|c|}{ White Mesa } \\
\hline $\begin{array}{l}\text { Jackpile Sandstone }{ }^{1} \\
\text { Do. } \\
\text { Do. } \\
\end{array}$ & $\begin{array}{l}\text { 85-Wm-13 } \\
85-W m-2 \\
85-W m-1 \\
\end{array}$ & $\begin{array}{l}+ \\
+ \\
--\end{array}$ & $\begin{array}{l}+(<0.1 \mathrm{I}) \\
+(<0.1 \mathrm{I}) \\
+(<0.1 \mathrm{I})\end{array}$ & $\ldots$ \\
\hline \multicolumn{5}{|c|}{ Encinal Canyon } \\
\hline $\begin{array}{l}\text { Encinal Canyon }{ }^{2} \\
\text { Do. } \\
\text { Do. } \\
\text { Do. } \\
\end{array}$ & $\begin{array}{l}86-E c-4 \\
86-E c-3 \\
86-E c-2 \\
86-E c-1 \\
\end{array}$ & $\begin{array}{l}\text { Trace } \\
\text { Trace } \\
\text { Trace } \\
-- \\
\end{array}$ & $\begin{array}{l}\text { Trace } \\
\text { Trace } \\
\text { Trace }(0.8 \mathrm{I} \text { ordered }) \\
+(0.6 \mathrm{I} \text { ordered }) \\
\end{array}$ & $\begin{array}{l}++ \\
++ \\
++ \\
\text { Trace } \\
\end{array}$ \\
\hline \multicolumn{5}{|c|}{ Galisteo Dam } \\
\hline Burro Canyon Formation & 86-Gd-1 & --- & $++(>0.9 \mathrm{I})$ & $\bar{\cdots}$ \\
\hline $\begin{array}{l}\text { Brushy Basin } 1 \\
\text { Morrison Formation } \\
\text { Do. } \\
\text { Do. }\end{array}$ & $\begin{array}{l}86-G d-2 \\
86-G d-6 \\
86-G d-4 \\
86-G d-3\end{array}$ & $\begin{array}{l}-- \\
-- \\
---\end{array}$ & $\begin{array}{l}++(>0.9 \mathrm{I}) \\
\text { Trace } \\
+(>0.75 \mathrm{I}) \\
++(>0.9 \mathrm{I})\end{array}$ & $\begin{array}{l}\cdots \\
+ \\
++ \\
\cdots\end{array}$ \\
\hline Recapture $^{1}$ & 86-Gd-7 & $\ldots$ & Trace & + \\
\hline \multicolumn{5}{|c|}{ Senorita Canyon } \\
\hline Brushy Basin 1 & $85-S c-1$ & $-\cdots$ & $++(<0.1 \mathrm{I})$ & Trace \\
\hline $\begin{array}{l}\text { Westwater Canyon }{ }^{1} \\
\text { Do. }\end{array}$ & $\begin{array}{l}85-S c-7 \\
85-S c-6 \\
\end{array}$ & -- & $\begin{array}{l}\text { Trace } \\
++(<0.1 \mathrm{I})\end{array}$ & --- \\
\hline \multicolumn{5}{|c|}{ Capulin Peak } \\
\hline $\begin{array}{l}\text { Brushy Basin } 1 \\
\text { Do. }\end{array}$ & $\begin{array}{l}85-C p-6 \\
85-C p-4\end{array}$ & $\begin{array}{l}--- \\
--\end{array}$ & $\begin{array}{l}++(<0.1 I) \\
+\end{array}$ & $\begin{array}{l}++ \\
++\end{array}$ \\
\hline $\begin{array}{l}\text { Westwater Canyon } 1 \\
\text { Do. } \\
\text { Do. }\end{array}$ & $\begin{array}{l}85-\mathrm{Cp}-10 \\
85-\mathrm{Cp}-9 \\
85-\mathrm{Cp}-8\end{array}$ & +- & $\begin{array}{l}++(<0.1 \mathrm{I}) \\
++(<0.1 \mathrm{I}) \\
+++(<0.1 \mathrm{I})\end{array}$ & $\begin{array}{l}++ \\
++ \\
++\end{array}$ \\
\hline $\begin{array}{l}\text { Recapture }^{1} \\
\text { Do. } \\
\text { Do. } \\
\text { Do. } \\
\end{array}$ & $\begin{array}{l}\text { 85-Cp-14 } \\
85-C \mathrm{p}-13 \\
85-\mathrm{Cp}-12 \\
85-\mathrm{Cp}-11 \\
\end{array}$ & $\begin{array}{l}-- \\
-- \\
--- \\
--\end{array}$ & $\begin{array}{l}+(<0.1 \mathrm{I}) \\
++(<0.1 \mathrm{I}) \\
++(<0.1 \mathrm{I}) \\
++(<0.1 \mathrm{I})\end{array}$ & $\begin{array}{l}+ \\
++ \\
++4 \\
++ \\
+4\end{array}$ \\
\hline \multicolumn{5}{|c|}{ Durango Hospital } \\
\hline $\begin{array}{c}\text { Recapture }^{1} \\
\text { Do. } \\
\text { Do. }\end{array}$ & $\begin{array}{l}\text { 85-Dh-6 } \\
\text { 85-Dh-4 } \\
\text { 85-Dh-3 }\end{array}$ & --- & $\begin{array}{l}+(>0.9 \mathrm{I}) \\
+(>0.9 \mathrm{I}) \\
+(>0.9 \mathrm{I})\end{array}$ & 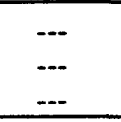 \\
\hline \multicolumn{5}{|c|}{ Dennison-Bunn } \\
\hline $\begin{array}{l}\text { Burro Canyon Formation } \\
\text { Do. }\end{array}$ & $\begin{array}{l}\text { 85-Db-2 } \\
85-\mathrm{Db}-1\end{array}$ & - & $\begin{array}{l}\text { Trace } \\
\text { Trace }\end{array}$ & $\begin{array}{l}-- \\
---\end{array}$ \\
\hline Brushy Basin 1 & $85-\mathrm{Db}-6$ & + & $+++(<0.1 \mathrm{I})$ & $\ldots$ \\
\hline $\begin{array}{l}\text { Westwater Canyon } 1 \\
\text { Do. } \\
\text { Do. } \\
\text { Do. }\end{array}$ & $\begin{array}{l}\text { 85-Db-11 } \\
85-\mathrm{Db}-10 \\
85-\mathrm{Db}-9 \\
85-\mathrm{Db}-8\end{array}$ & --. & $\begin{array}{l}++(<0.1 \mathrm{I}) \\
+(<0.1 \mathrm{I}) \\
\text { Trace. } \\
++(<0.1 \mathrm{I})\end{array}$ & $\begin{array}{l}+- \\
+ \\
+++ \\
++\end{array}$ \\
\hline $\begin{array}{l}\text { Recapture }^{1} \\
\text { Do. } \\
\text { Do. }\end{array}$ & $\begin{array}{l}\text { 85-Db-16 } \\
\text { 85-Db-15 } \\
\text { 85-Db-14 }\end{array}$ & $\begin{array}{l}\text { Trace } \\
---\end{array}$ & $\begin{array}{l}++(<0.1 \mathrm{I}) \\
++(<0.1 \mathrm{I}) \\
+++(<0.1 \mathrm{I})\end{array}$ & $\begin{array}{l}+ \\
\text { Trace } \\
\text { Trace }\end{array}$ \\
\hline
\end{tabular}

analcime-cemented sandstones are adjacent to analcimized tuff beds (fig. 13B). Potassium feldspar grains are albitized, and complete albitization has formed "chessboard albite" grains (fig. 14) that look identical to those reported by Walker (1984); however, electron microprobe analyses were not made of the grains to check for potassium feldspar remnants such as Walker found. Just to the south of Beclabito dome, at Oak Springs, sandstones contain abundant potassium feldspar overgrowths but fewer albite overgrowths than at Beclabito dome. Farther south, diagenetic alterations are less complex, except in the upper part of the Westwater 


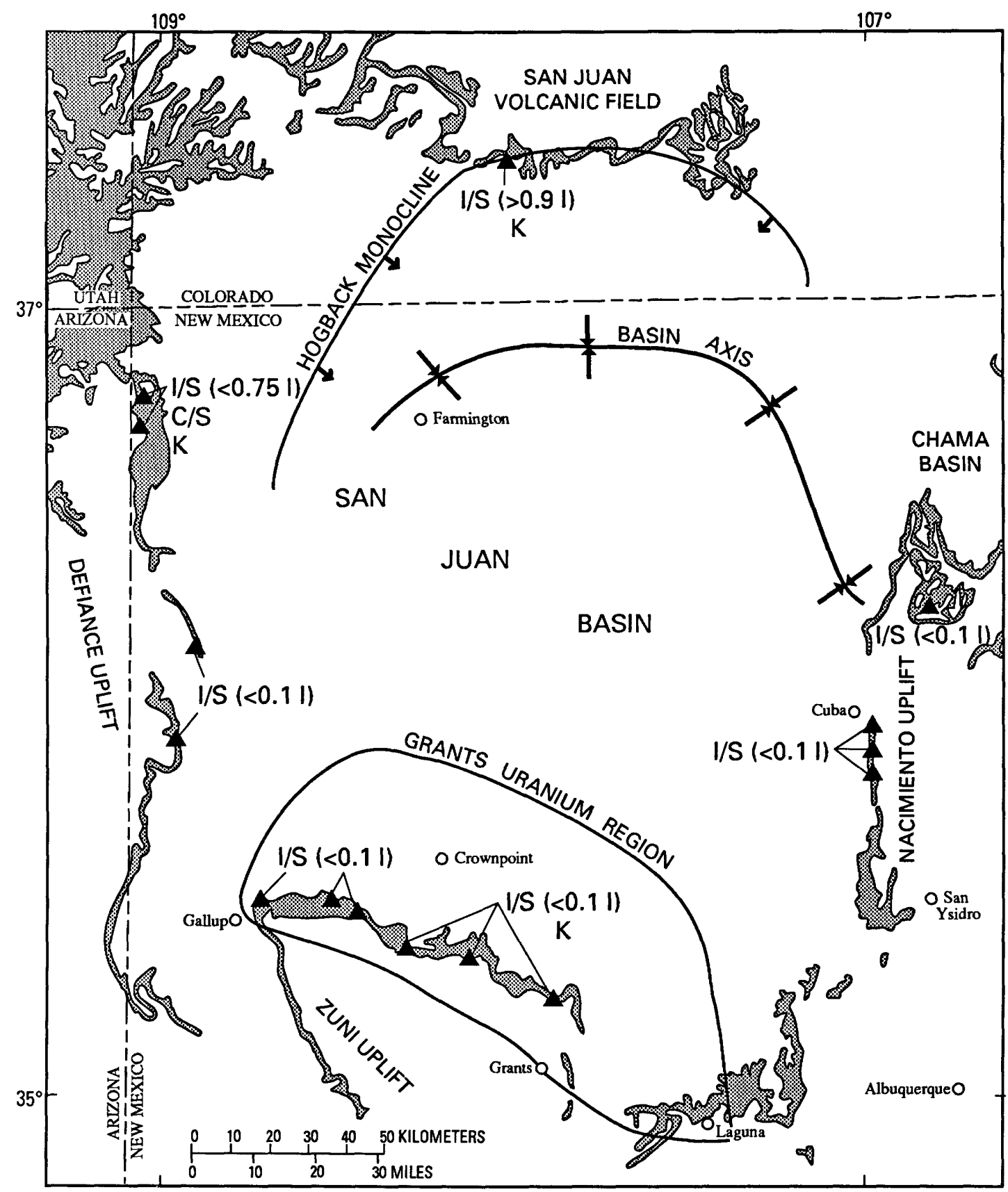

Figure 8 (above, facing, and following page). Regional distribution of major authigenic clay minerals in the Morrison Formation (pattern), San Juan basin. Sample localities indicated by triangles. K, kaolinite; $\mathrm{I} / \mathrm{S}$, illite/smectite, 0.71 means 70 percent illite in $\mathrm{I} / \mathrm{S} ; \mathrm{C} / \mathrm{S}$, chlorite/smectite $(>0.9 \mathrm{C})$. $A$, Recapture Member; $B$, Westwater Canyon Member; $C$, Brushy Basin Member.

Canyon Member where quartz overgrowths, but no detrital plagioclase, are present. The lack of plagioclase is due to dissolution because, proceeding downward, skeletal plagioclase grains appear and finally near the base of the member entire grains are preserved. Kaolinite (as an alteration of plagioclase?) is a common pore-filling cement. Along the southern margin of the basin, sandstone grains commonly are coated with thick hematite rims, which in turn are overlain by chlorite, quartz overgrowths, kaolinite, and calcite cement.

Additional potassium metasomatism of plagioclase grains having anti-rapakivi textures and formation of potassium feldspar overgrowths were caused by fluids that escaped into the sandstones from associated saline, alkaline beds. (See, for example, Oak Springs and Dennison-Bunn sections.) The precipitation during early 


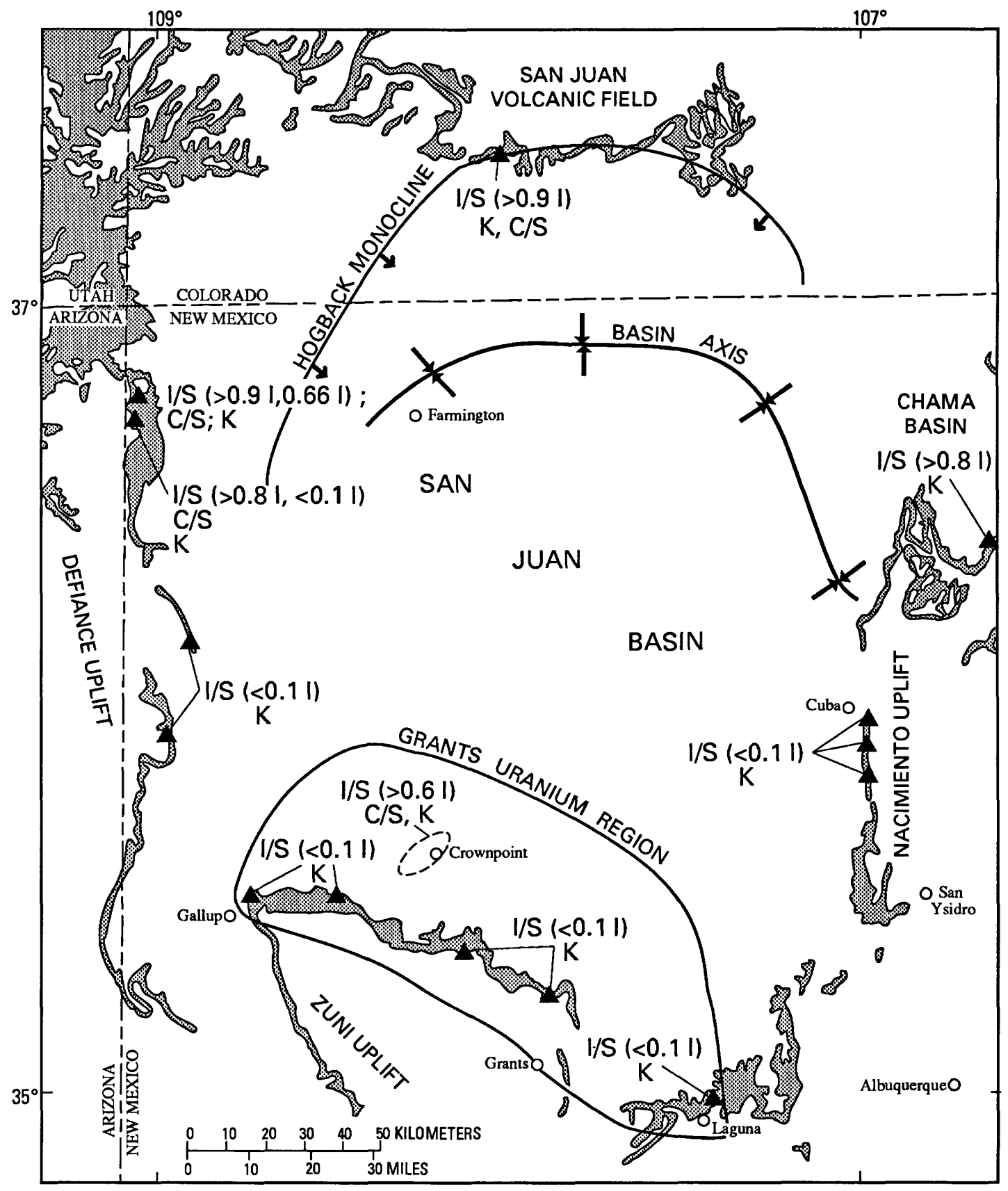

diagenesis of potassium feldspar overgrowths is suggested by the occurrence of these overgrowths under poikilotopic calcite cement in which framework grains float (fig. 15A). Potassium feldspar overgrowths are coated with early hematite cement in sandstones at the Dennison-Bunn section (fig. 15B). Potassiummetasomatized plagioclase has also been found in Cenozoic saline, alkaline lake deposits (Hay, 1966).

Not all development of authigenic potassium feldspar was caused by fluids from the Brushy Basin Member because these distinctive grains occur throughout the basin in all depositional facies, not just in sandstones adjacent to or in the saline, alkaline lake facies.
Abundant authigenic potassium feldspar also occurs in and adjacent to ore zones. Where the paragenetic sequence could be determined in ore zones, a major episode of potassium metasomatism and overgrowth formation could be seen to have occurred after chlorite rim precipitation.

Trends in the distributions of authigenic clay minerals exhibit similar patterns. For instance, at Beclabito dome authigenic I/S ranges from $0.5 \mathrm{I}$ to $0.9 \mathrm{I}$, and near the top of the section rectorite (a perfectly ordered ISIS mixture) is indicated by the presence of a superlattice peak (fig. 16). Chlorite is the most abundant clay mineral at the top of the Westwater Canyon Member; it 


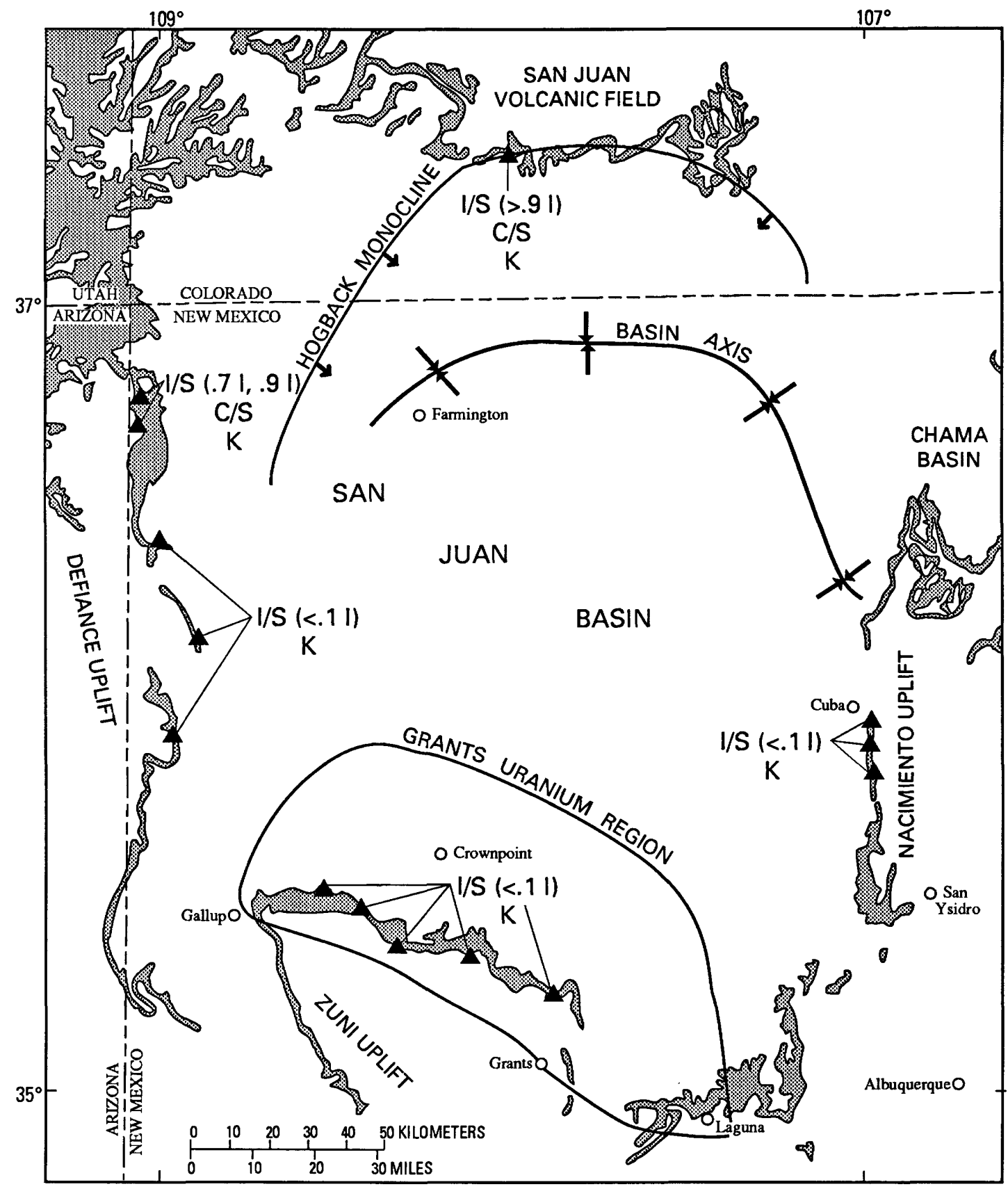

overgrows expandable I/S and is intergrown with illitic I/S (X-ray diffractograms indicate the presence of two I/S phases). Similar authigenic clay mineralogy is present in the Chaco Canyon cores (fig. 17). Variable amounts of kaolinite and chlorite occur in most samples. Directly to the south of Beclabito dome, at Oak Springs, I/S (0.3-0.6I) is dominant and is accompanied by major chlorite, minor kaolinite, and illitic I/S $(>0.8 \mathrm{I})$. Proceeding farther southward along the western side of the basin, expandable I/S $(<0.1-0.5 \mathrm{I})$ occurs at Sanostee Wash and more expandable I/S $(<0.1 \mathrm{I})$ at Asaayi Lake and Toadlena. Kaolinite is dominant at all three localities but is more abundant to the south, whereas chlorite becomes less abundant southward.

On the eastern side of the basin, authigenic claymineral trends are also evident. At the easternmost locality, Galisteo Dam, clay minerals are mainly kaolinite and ordered I/S (0.66I), whereas along the Nacimiento uplift authigenic clays are more expandable $(<0.1 \mathrm{I})$. Major kaolinite occurs with minor expandable I/S $(<0.1 \mathrm{I})$ at Capulin Peak, and just to the south at San Pablo Canyon clays are predominantly kaolinite. In the southeastern part of the basin, at Laguna, I/S $(<0.1 \mathrm{I})$ is also expandable. 


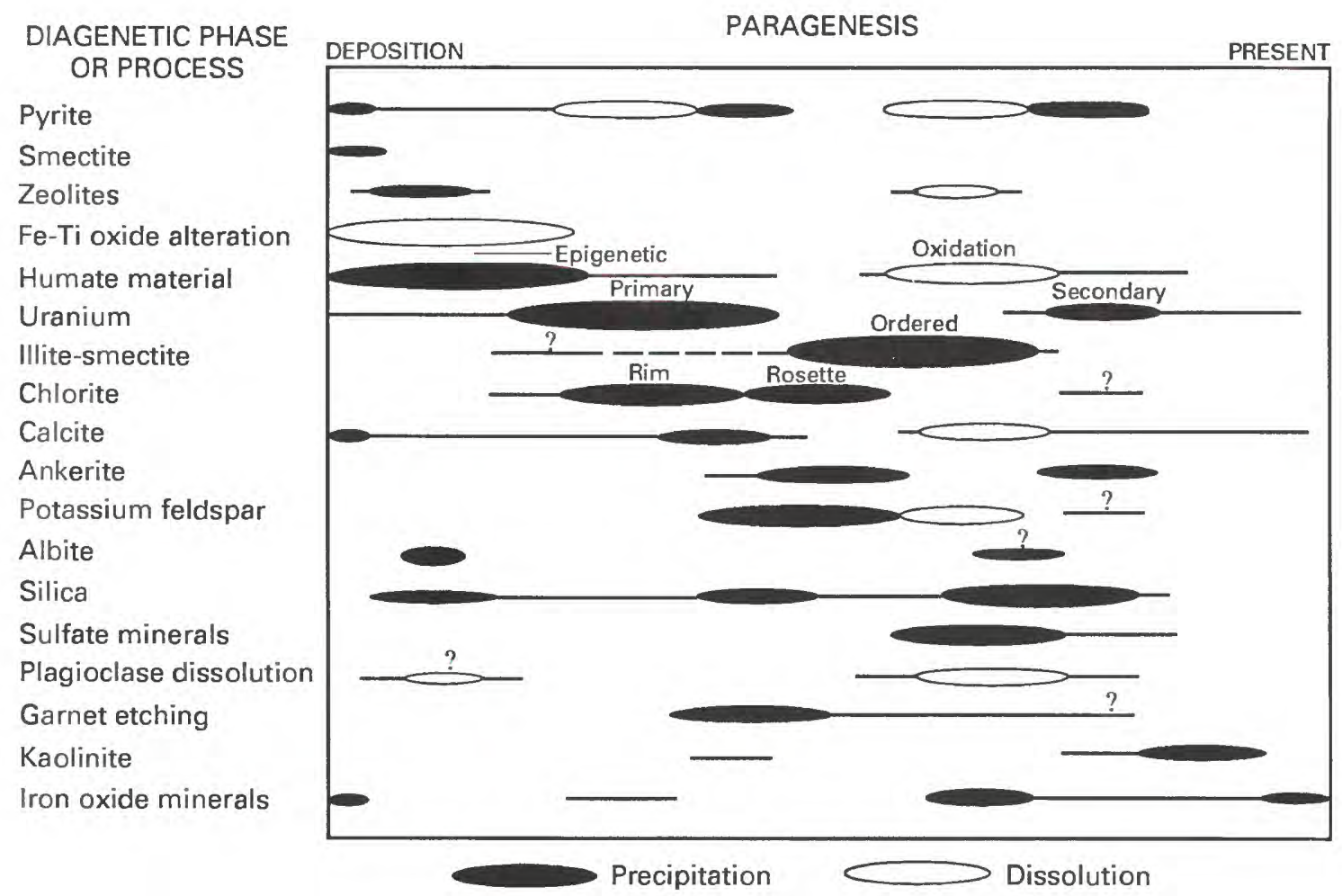

Figure 9. Paragenesis of major authigenic phases and diagenetic events in the Morrison Formation.

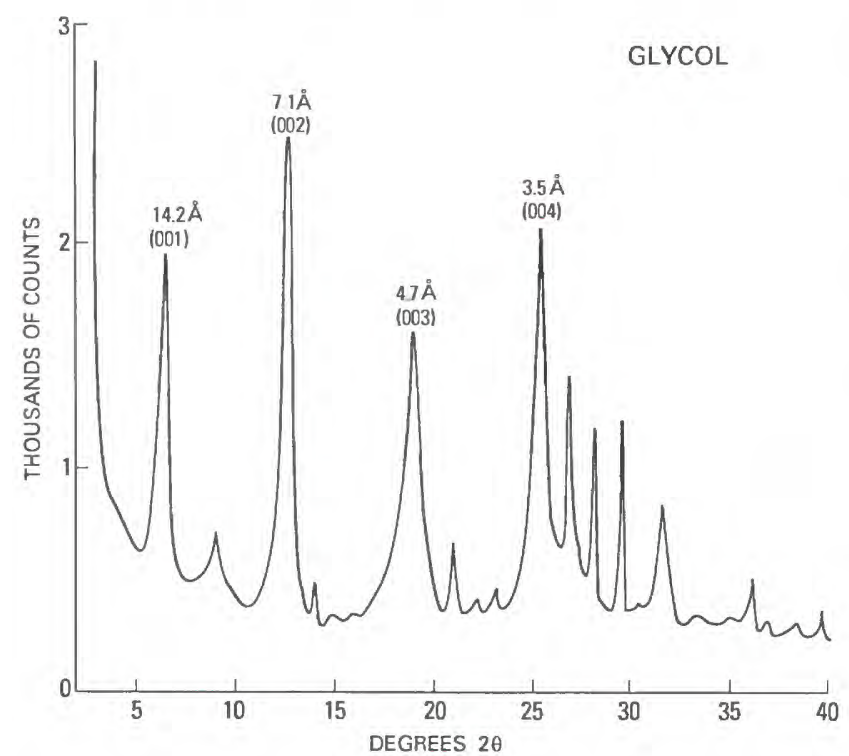

Figure 10. X-ray diffractogram of authigenic nonferroan chlorite in sandstone of the Westwater Canyon Member at Beclabito dome.

In the cores, diagenetic alterations also increase both vertically and to the north. In the northernmost and deepest core (Chaco Canyon core), analcime has replaced some plagioclase grains (also noted in other Chaco Canyon cores by Hicks, 1981); however, most

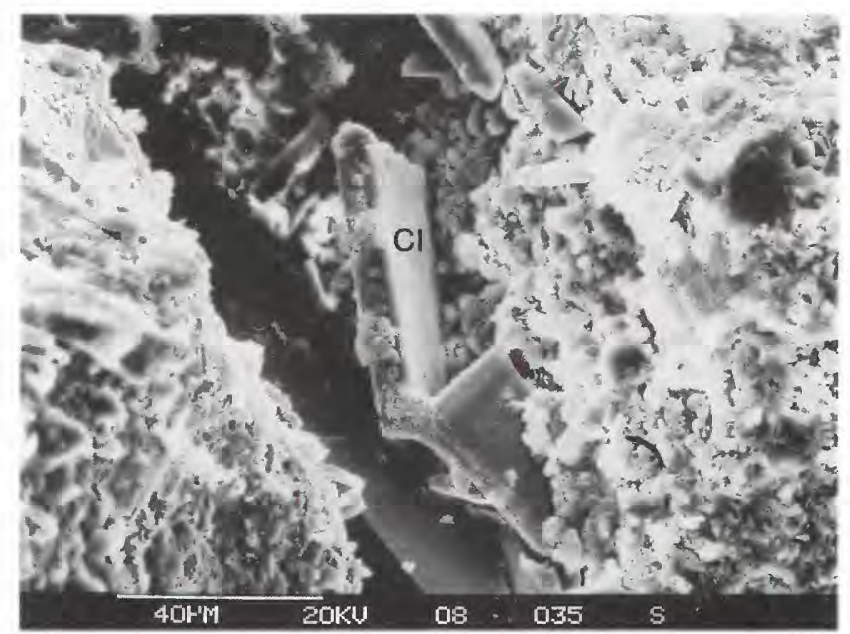

Figure 11. Scanning electron micrograph showing clinoptilolite crystals $(\mathrm{Cl})$ in a sandstone pore of the Westwater Canyon Member at Beclabito dome. Length of field, $0.16 \mathrm{~mm}$.

plagioclase is albitized. Chlorite rosettes occur commonly in pores. Two stages of quartz overgrowths are present, and in the lower part of the Westwater Canyon Member anhydrite fills pores rimmed by quartz overgrowths. Hollow albite rims that look identical to hollow potassium feldspar rims occur in the cores farthest to the northeast. Associated plagioclase grains are albitized, and rare chlorite rims are under albite overgrowths. 


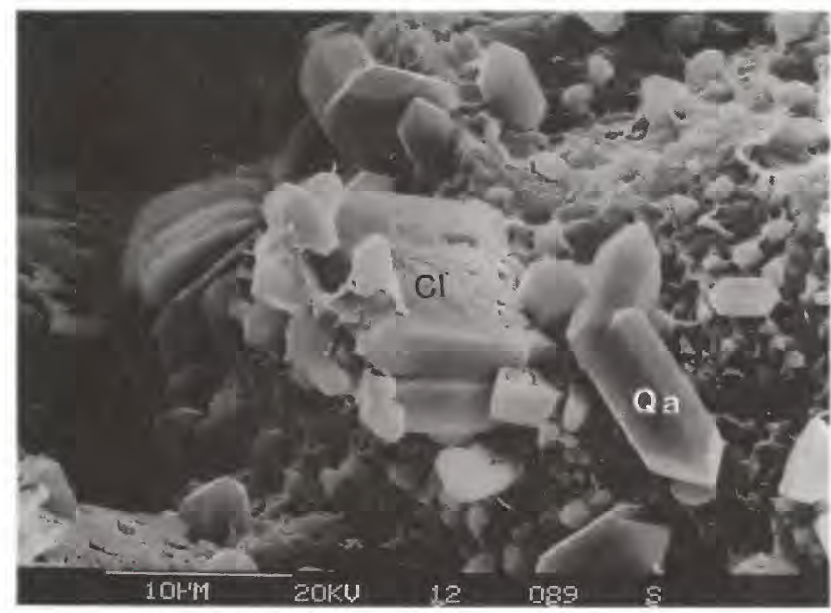

Figure 12. Scanning electron micrograph showing clinoptilolite $(\mathrm{Cl})$ intergrown with authigenic idiomorphic quartz $(\mathrm{Q} a)$ in sandstone pore of the upper part of the Westwater Canyon Member at Beclabito dome. Length of field, $45 \mu \mathrm{m}$.

In the other cores, authigenic chalcedony cement, quartz overgrowths, and skeletal plagioclase grains are most common in the upper part of the Westwater Canyon Member.

Many diagenetic alterations are best developed in and adjacent to uranium-bearing sandstones; such is the case in the USGS cores (Hansley, 1986b). For example, in and adjacent to coffinite-bearing sandstone in core H-26-22, grains are cemented with pyrite, large quartz overgrowths, and potassium feldspar overgrowths. Abundant early authigenic potassium feldspar and hollow potassium feldspar rims are notable among alterations associated with uranium enrichment. As noted previously, the high amount of primary porosity (filled with calcite) in these sandstones provides evidence that potassium feldspar overgrowths formed early. A similar association of uranium enrichment and authigenic silica has been noted in the Morrison Formation in other areas of the Colorado Plateau (Goldhaber and others, 1987).

\section{Brushy Basin Member}

Regional diagenetic alteration patterns are well established in sandstones of the Brushy Basin Member. As in the other members, diagenetic alterations are more advanced from south to north; however, the severity of diagenesis varies widely from sandstone to sandstone within one outcrop. The Brushy Basin Member is characterized throughout the basin by mixed-layer clays, silica, and zeolite cements. As many as four distinct generations of chalcedony cement may be present (fig. 18), and the minimal diagenetic alteration of framework grains in these silica-cemented samples indicates that the silica cements were precipitated during early diagenesis.
In the northern part of the basin at the Durango Hospital and Piedra River outcrops, porosity is close to zero because the sandstones are cemented with quartz and albite overgrowths (fig. 19) and later formed porefilling chalcedony and calcite (fig. 20). Small potassium feldspar overgrowths are on some detrital potassium feldspar grains at Durango, but just to the east, at Piedra River, most potassium feldspar has been completely albitized. Most plagioclase grains are albitized, and those at the top of the member commonly are replaced by analcime. At both sections, hematite, dolomite, and anhydrite cements locally replaced earlier diagenetic minerals.

On the other hand, in the southeastern part of the basin at Laguna, plagioclase grains are skeletalized and albitized and large areas of framework grains are cemented by kaolinite (fig. 21). Remnants of calcite cement occur in pores, and albite and quartz overgrowths are abundant. To the east, at Galisteo Dam, chert and chalcedony cement are major diagenetic alterations, and micron-size, authigenic, twinned and doubly terminated albite crystals occur in pores.

On the eastern side of the basin, along the Nacimiento uplift, diagenetic alterations decrease from north to south. Sandstone grains are intensely zeolitized at Senorita Canyon: analcime has replaced feldspar and molds of shards are infilled with analcime. Grainrimming chert or smectite is superceded by pore-filling chalcedony or analcime. Plagioclase exhibits minor dissolution textures. On the other hand, sections to the south contain few zeolites. Sandstone matrix at San Pablo Canyon, just to the south of Senorita Canyon, is mostly smectitic and contains few zeolitized or albitized plagioclase grains and minor zeolite cement. Farther to the south, at White Mesa, sandstones are characterized by abundant smectite and by silica cement that has been superceded locally by calcite.

In the northwestern corner of the basin, at Beclabito dome and Oak Springs, some sandstone beds have a matrix comprised of authigenic smectite; other beds contain a wide variety of zeolites, authigenic feldspars, and illitic I/S. Many sandstone grains are coated with low-birefringent smectite rims surrounding voids filled with analcime, calcite, or chalcedony. Shardlike molds are filled with microcrystalline silica and rimmed by albite(?). Albitization of potassium feldspar has produced grains that appear to be "chessboard albite", and untwinned plagioclase locally is skeletalized and albitized. Albite overgrowths are more abundant at Beclabito dome than at Oak Springs, and potassium feldspar overgrowths were not noted at either section. At both sections, sandstones near the base of the member contain oxidized pyrite, barite cement, and small potassium feldspar overgrowths. An inverse correlation exists between the abundance of analcime and albite: 

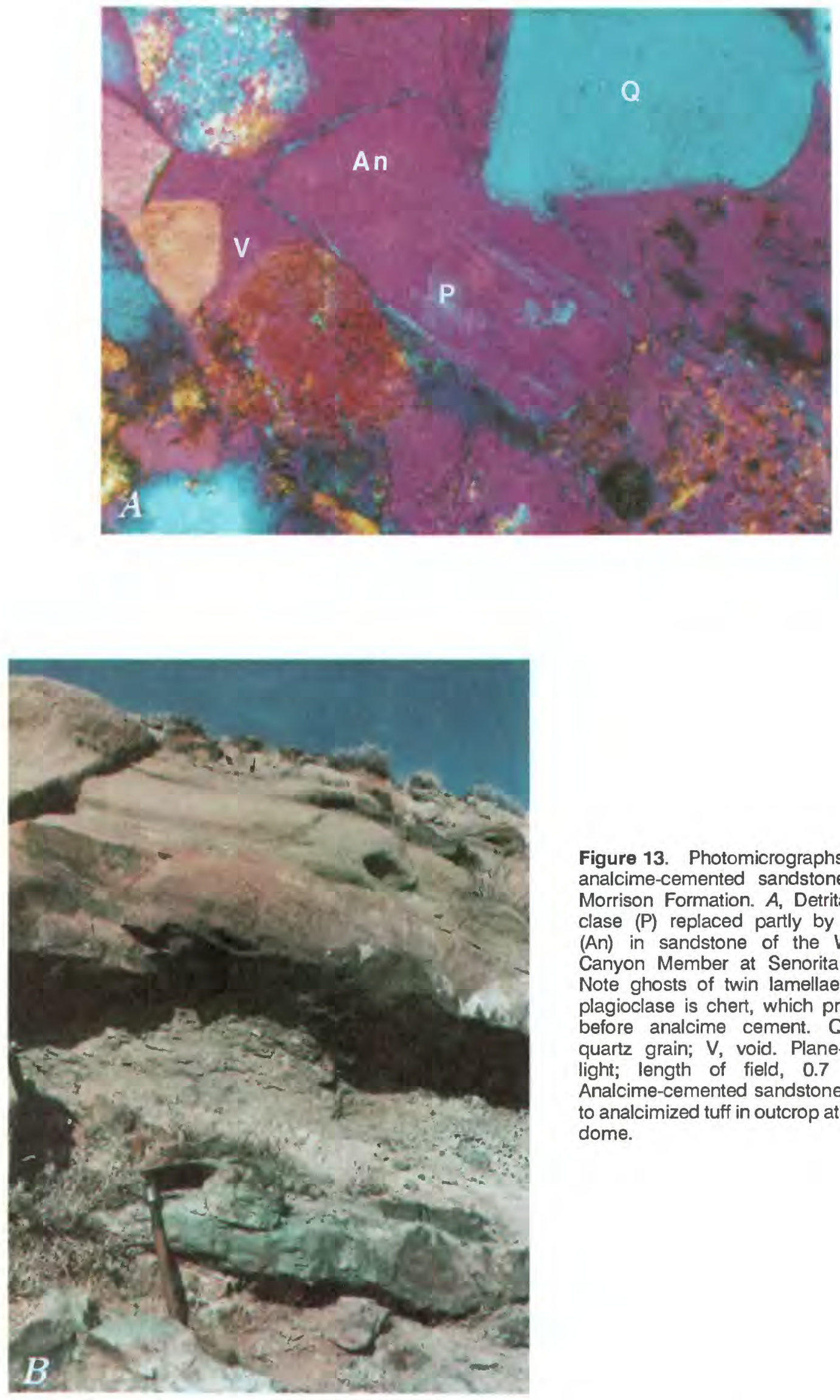

Figure 13. Photomicrographs showing analcime-cemented sandstones in the Morrison Formation. $A$, Detrital plagioclase $(\mathrm{P})$ replaced partly by analcime (An) in sandstone of the Westwater Canyon Member at Senorita Canyon. Note ghosts of twin lamellae. Rim on plagioclase is chert, which precipitated before analcime cement. $Q$, detrital quartz grain; V, void. Plane-polarized light; length of field, $0.7 \mathrm{~mm}$. $B$, Analcime-cemented sandstone adjacent to analcimized tuff in outcrop at Beclabito dome. 


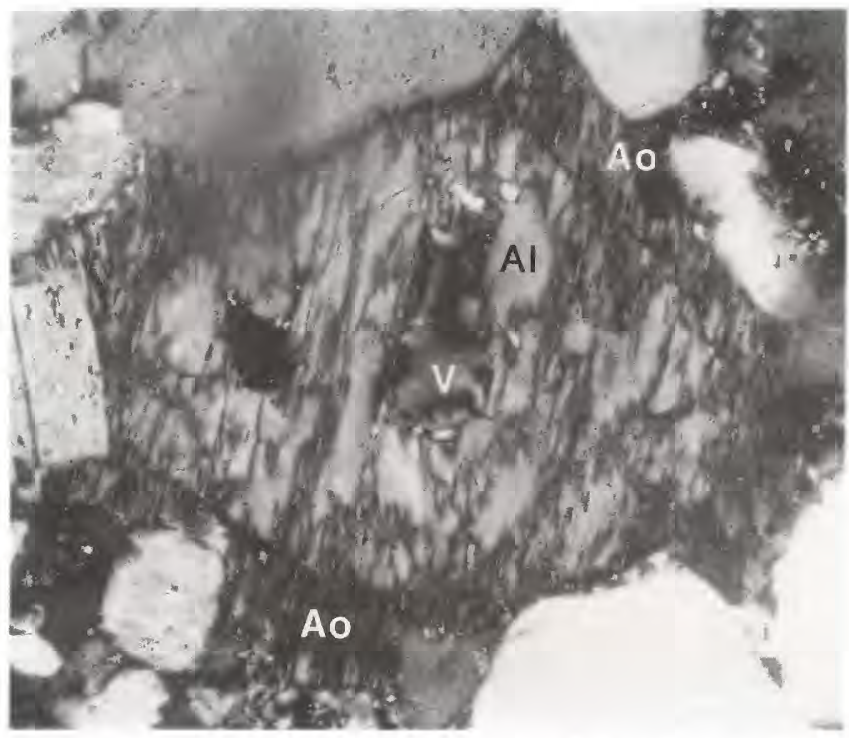

Figure 14. Photomicrograph showing "chessboard albite" grain (Al) in sandstone of the upper part of the Westwater Canyon Member at Beclabito dome. Note albite overgrowths (Ao) on grain; V, void. Crossed polars; length of field, 0.5 $\mathrm{mm}$.

sandstone beds either have abundant analcime and few quartz or feldspar overgrowths or have abundant albite and quartz overgrowths and little or no analcime. Grains in the highest sandstones at Oak Springs contain fractures filled with analcime.

Clay minerals exhibit similar regional alteration patterns: to the south, mixed-layer clay minerals are highly expandable, whereas to the north and northwest they become increasingly illitic. In the northwestern part of the basin, at Beclabito dome, major I/S $(>0.8 \mathrm{I})$ and minor chlorite (fig. 22) occur in the lower half of the Brushy Basin Member; dominant chlorite and minor I/S (0.6-0.7I) and kaolinite occur in the upper half. The I/S is intergrown with authigenic quartz (fig. 23) and appears to overgrow clinoptilolite (fig. 24). At the top of the Brushy Basin Member, well-defined rectorite (0.6I) and minor kaolinite occur; no chlorite was observed. Just a few miles to the south at Oak Springs, sandstones of the lower Brushy Basin contain major chlorite and I/S $(<0.1 \mathrm{I})$ and minor kaolinite. In sandstones of the upper Brushy Basin at Oak Springs, I/S (0.3-0.6I) is the major clay mineral. The clay mineralogy of the northernmost section at Durango is similar to that of Beclabito dome in that $\mathrm{I} / \mathrm{S}(>0.9 \mathrm{I})$ is dominant.

Along the Nacimiento uplift, major authigenic clay minerals are kaolinite and expandable I/S $(<0.1 \mathrm{I})$; farther to the east, at Galisteo Dam, major kaolinite and minor I/S (0.85I; ISII stacking) are present. Chlorite is not a major phase in these eastern sections.
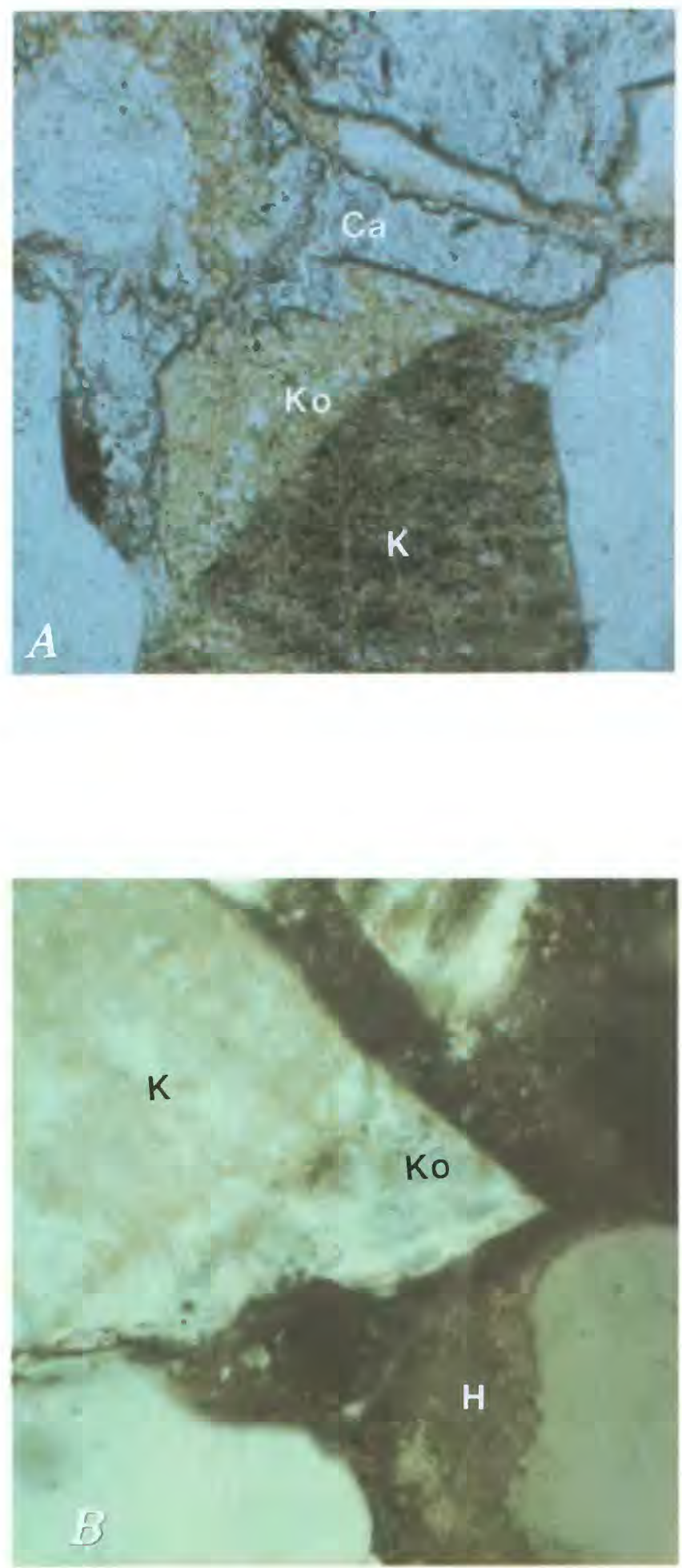

Figure 15. Photomicrographs showing potassium feldspar overgrowth on detrital potassium feldspar, Dennison-Bunn section. A, Early potassium feldspar overgrowth (Ko) on detrital potassium feldspar $(K)$ in calcite-cemented $(\mathrm{Ca})$ sandstone. Note floating grains and point contacts. Planepolarized light; length of field, $0.2 \mathrm{~mm}$. B, Potassium feldspar overgrowth (Ko) coated with hematite cement $(H)$ in sandstone. $\mathrm{K}$, detrital potassium feldspar. Plane-polarized light; length of field, $0.05 \mathrm{~mm}$. 


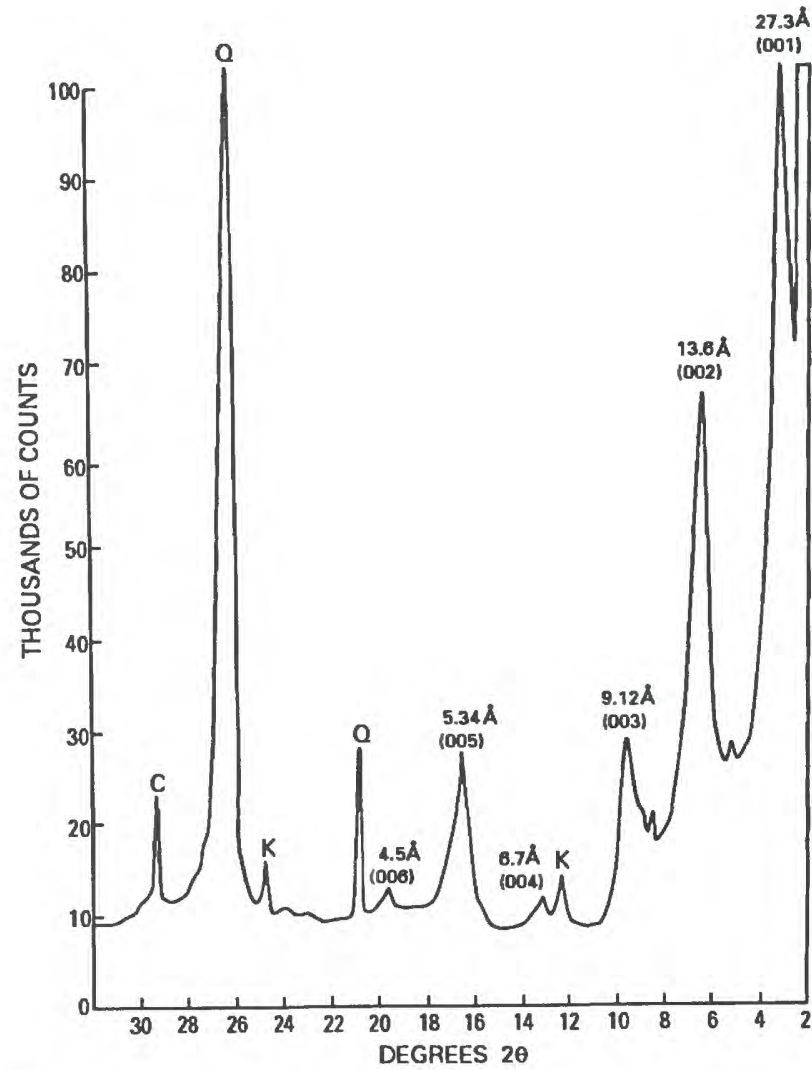

Figure 16. X-ray diffractogram of well-ordered I/S (rectorite; ISIS ordering) showing development of a superlattice reflection at $27.3 \AA$. Rectorite peaks are labeled in angstroms. Q, detrital quartz; K, kaolinite; C, calcite. Sample is from a sandstone near the top of the Westwater Canyon Member at Beclabito dome.

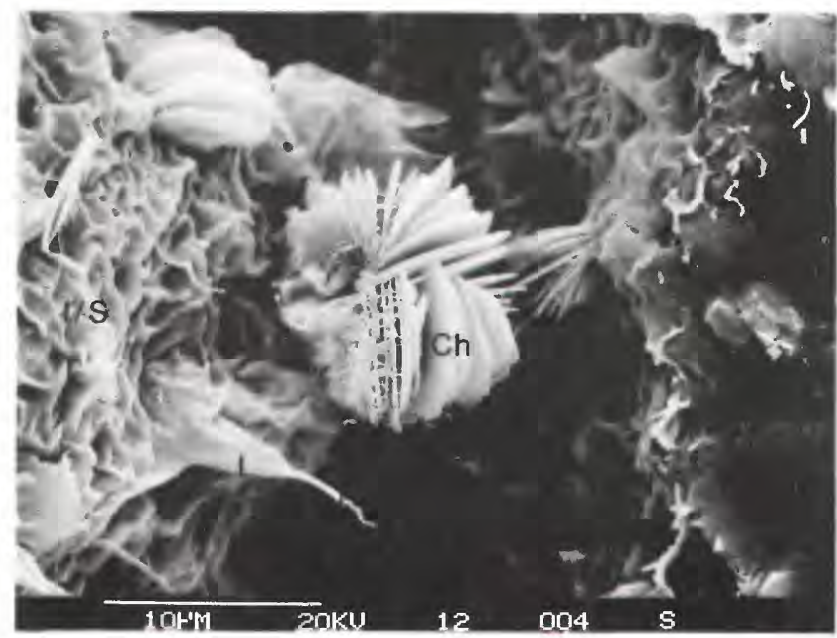

Figure 17. Scanning electron micrograph showing authigenic chlorite rosette (Ch) and intergrown illitic I/S filaments. Chlorite is resting on expandable I/S that has illitic overgrowths (I). Length of field, $35 \mu \mathrm{m}$. Sample is from the Westwater Canyon Member in the Chaco Canyon core (CC-12, fig. 1).

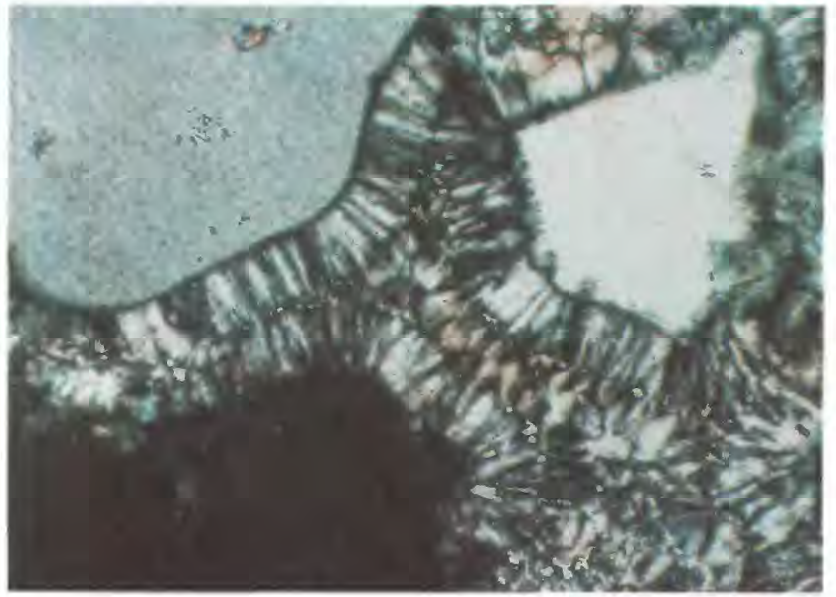

Figure 18. Photomicrograph showing several generations of chalcedony cement in sandstone of the Brushy Basin Member at the Piedra River section. Crossed polars; length of field, $0.2 \mathrm{~mm}$.

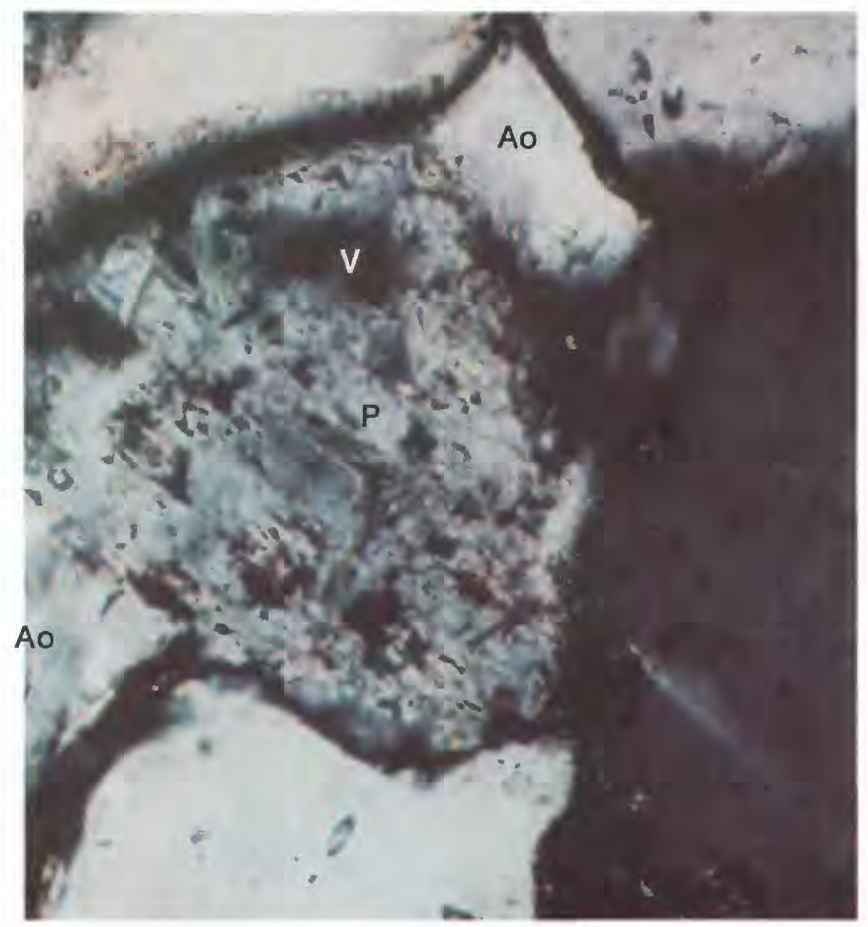

Figure 19. Photomicrograph showing authigenic porefilling albite overgrowths $(\mathrm{AO})$ on albitized plagioclase $(\mathrm{P})$ in a sandstone of the Brushy Basin Member at the Durango Hospital section. V, void. Crossed polars; length of field, 0.1 $\mathrm{mm}$.

\section{Jackpile Sandstone Member}

At the Laguna type section, the Jackpile Sandstone Member is characterized by abundant kaolinite cement especially at the top, few plagioclase grains, and quartz grains displaying feathery dissolution edges. Toward the base, plagioclase grains commonly are albitized. This 


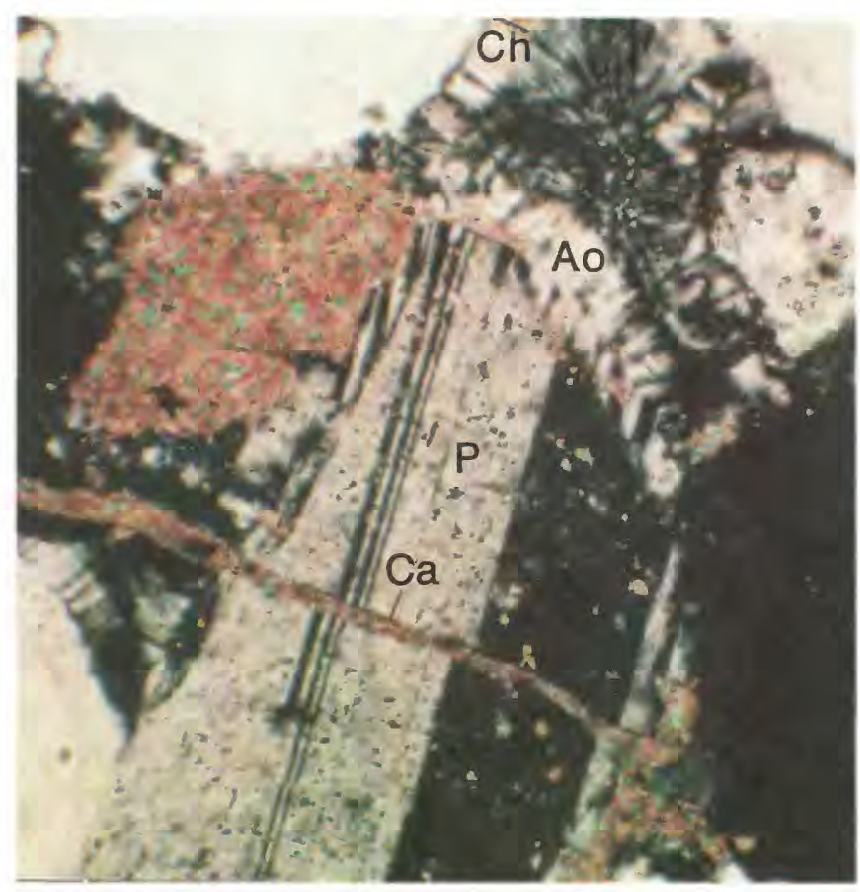

Figure 20. Photomicrograph showing detrital twinned plagioclase grain $(\mathrm{P})$ with albite overgrowth $(\mathrm{AO})$ and later chalcedony cement $(\mathrm{Ch})$ in pore and calcite $(\mathrm{Ca})$ in fracture. Sample is from the Brushy Basin Member at the Durango Hospital section. Crossed polars; length of field, $0.15 \mathrm{~mm}$.

distribution of kaolinite at the top and albite at the bottom was also noted by Nash (1968) and Adams and others (1974). Quartz overgrowths are locally abundant, and minor hematite cement is present. In nearby Encinal Canyon, the Jackpile contains kaolinite and minor I/S $(<0.1 \mathrm{I})$ and chlorite. Farther to the northeast, at White Mesa, two expandable I/S phases are present $(0.3 \mathrm{I}$ and $<0.1$ ). In contrast to Laguna, plagioclase grains are unaltered at White Mesa and sandstones are more silicic because thin quartz overgrowths are superseded by chalcedony cement. Farther to the north at San Pablo Canyon, two generations of (early) chalcedony commonly fill primary pores, and framework grains are fresh except for thin (early) potassium feldspar overgrowths on potassium feldspar.

\section{Cretaceous sandstones}

The overlying fluvial Cretaceous units, the Burro Canyon Formation (Lower Cretaceous) and the Encinal Canyon Member of the Dakota Sandstone (Upper Cretaceous), are more siliceous than most sandstones of the Morrison. The Cretaceous sandstones are comprised of quartz, chert, quartzite, and little or no plagioclase. Kaolinite is the most abundant clay mineral and is accompanied by minor detrital(?) I/S ( $>0.9 \mathrm{I})$. At

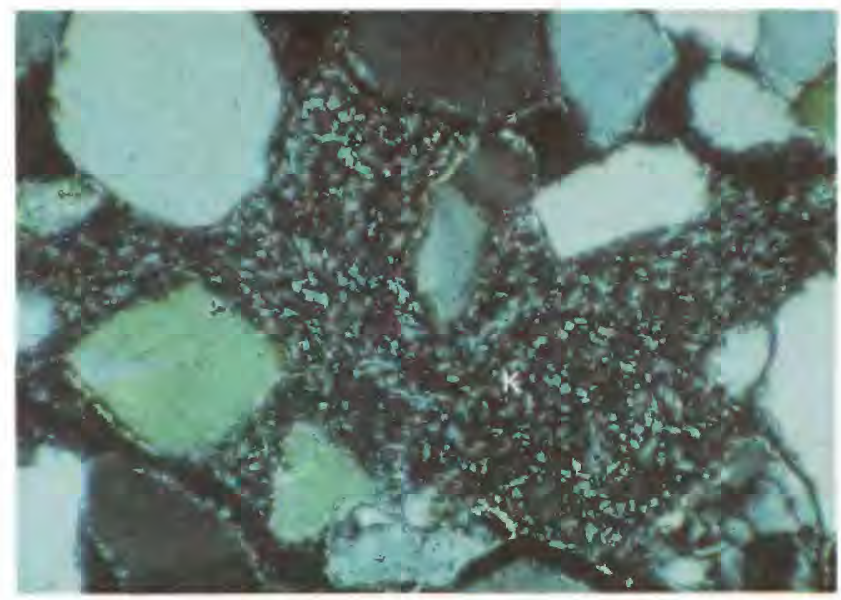

Figure 21. Photomicrograph showing pore-filling kaolinite cement $(K)$ in sandstone at Laguna section. Crossed polars; length of field, $0.25 \mathrm{~mm}$.

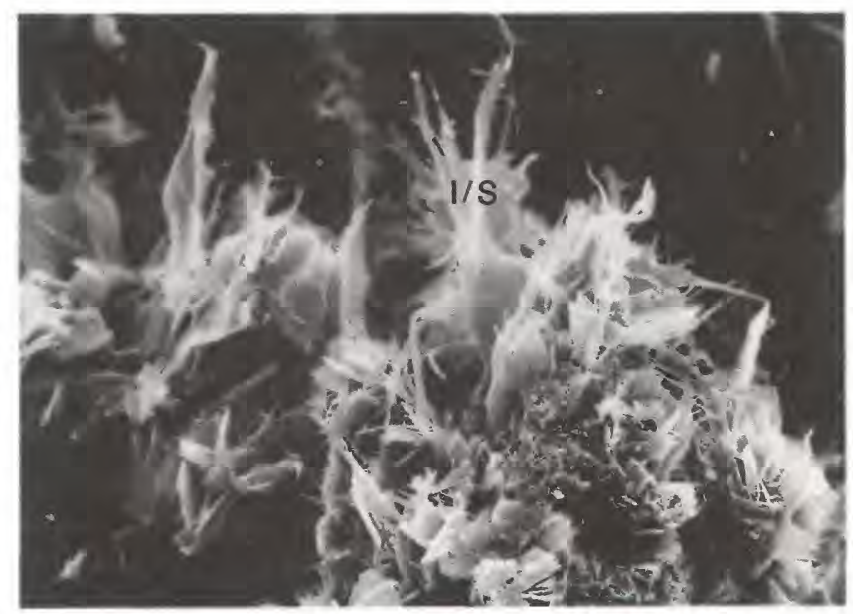

Figure 22. Scanning electron micrograph showing I/S $(>0.81)$ in sandstone of the Brushy Basin Member at Beclabito dome. Length of field, $45 \mu \mathrm{m}$.

Beclabito dome, the overlying fluvial Cretaceous sandstones (Burro Canyon? Formation) have an authigenic smectite matrix.

\section{BURIAL HISTORY}

A map of vitrinite reflectance values $\left(R_{0}\right)$ measured on coals in the Dakota Sandstone and Fruitland Formation in the San Juan basin (fig. 25) was constructed using data from many sources (Russell, 1979; Dow, 1982; Keal, 1982; Rice, 1983; Jacobson and others, 1985; Bayliss and Schwarzer, 1987, 1988; N.H. Bostick, USGS, written commun., 1988; V.F. Nuccio, USGS, written commun., 1988). Values increase from southwest to northeast across the basin, and lower values 


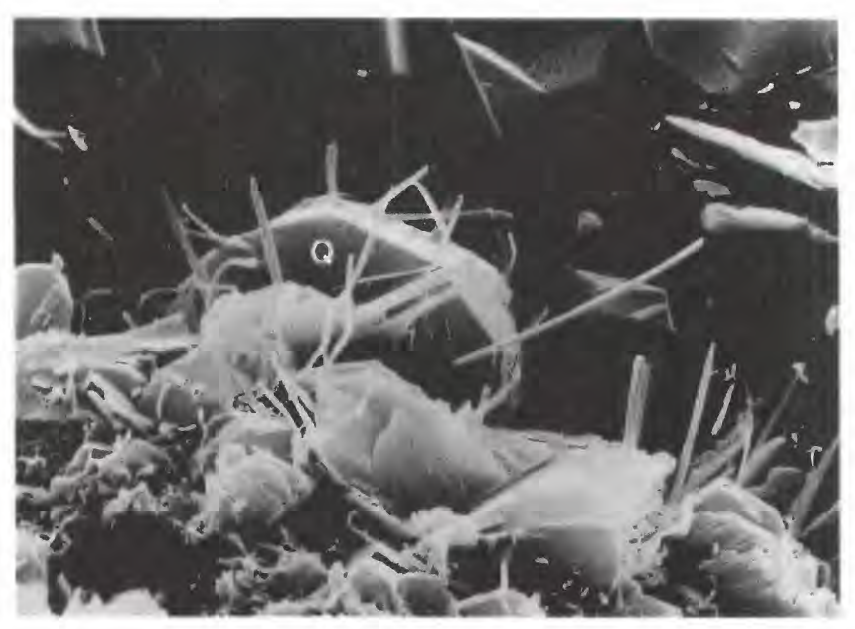

Figure 23. Scanning electron micrograph showing intergrowth of illitic I/S (>0.8 I) needles and euhedral authigenic quartz (Q) in sandstone of the Brushy Basin Member at Beclabito dome. Length of field, $9 \mu \mathrm{m}$.

are generally in the southern part of the basin and along basin margins. As Rice (1983) pointed out, lines of equal vitrinite reflectance curve in the northwestern part of the basin such that they appear to follow the trend of the Hogback monocline. Maximum burial of the Morrison Formation was approximately $2,300-3,200 \mathrm{~m}$ in the deepest part of the basin (Weeks and Garrels, 1959, table 1); however, maximum $R_{o}$ values do not coincide with either maximum burial depths or the basin axis because the highest $R_{o}$ values in the basin $(>2.5)$ (Rice, 1983; V.F. Nuccio, written commun., 1988) in the basin are just south of Durango.

The Morrison Formation may have been subjected to a higher geothermal gradient in the northern San Juan basin because of proximity to the San Juan Volcanic Field (fig. 1). Bond (1984) constructed a Lopatin diagram of a well just south of Durango for which $\mathbf{R}_{\mathrm{o}}$ values are the highest in the basin that led him to conclude that maximum burial of the geologic section coincided with a "heat flash" caused by Oligocene intrusive activity related to the San Juan Volcanic Field. If this is the case, however, $R_{0}$ values should be elevated in the Durango area, but $R_{o}$ values of Cretaceous coals are relatively low in the area of the San Juan Volcanic Field (Nuccio and Johnson, 1988) and in outcrops (0.8) (Rice, 1983) in the Durango area just north of the anomalously high values. As an alternate explanation for the high $R_{o}$ values just south of Durango, Clarkson and Reiter (1987) suggested that a buried heat source (such as a magma) just south of Durango accounts for the disparity in $R_{o}$ values over a distance of less than $24 \mathrm{~km}$. Along the Hogback monocline, the Morrison Formation was exposed from Late Cretaceous to early Tertiary time (Kelley and Clinton, 1960). Thus, shallow burial may explain the low levels of maturity along the monocline,

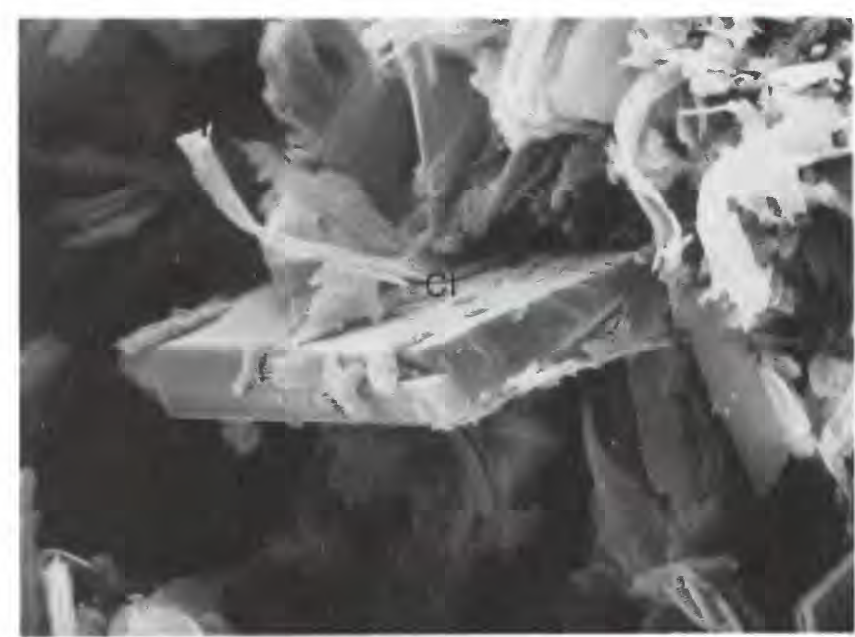

Figure 24. Scanning electron micrograph showing illitic $/ / S$ $(>0.8 \mathrm{I})$ clay $(\mathrm{I})$ on clinoptilolite $(\mathrm{Cl})$ in sandstone pore. Sample is from the Brushy Basin Member at Beclabito dome. Length of field, $25 \mu \mathrm{m}$.

and the abnormally high maturity of the section in the area south of Durango may be explained by maximum heating having occurred during deepest burial. Coincidence of deepest burial with maximum heating of sediments results in rapid maturation and, in many cases, overwhelms the effects of time (Waples, 1985).

Regardless of the reason for the wide variation in $\mathbf{R}_{\mathrm{o}}$ values, even at inferred minimum depths of burial (about 2,000 m) (Haun and Weimer, 1960) of the Morrison Formation along the Hogback monocline, temperatures would have been approximately $74-98^{\circ} \mathrm{C}$ due to burial alone assuming a geothermal gradient of $27-34{ }^{\circ} \mathrm{C}$ for the Rocky Mountain region (American Association of Petroleum Geologists and U.S. Geological Survey, 1975).

\section{INTERPRETATION OF DIAGENESIS}

Regional diagenetic alteration patterns in sandstones of the Morrison Formation indicate that controls on diagenetic reactions were basinwide and included chemical gradients in saline, alkaline Lake T'oo'dichi'; updip migration of warm ground water due to compaction; differential burial; and influx of meteoric water. In addition, diagenetic alterations were influenced locally by chemical reactions related to concentrations of organic matter (Hansley, 1986b).

The refractory nature of the present-day detrital heavy-mineral assemblage reflects the silicic composition of source rocks, long-distance transport from source areas, and postdepositional diagenetic processes. Upward increases in euhedral apatite and zircon abun- 


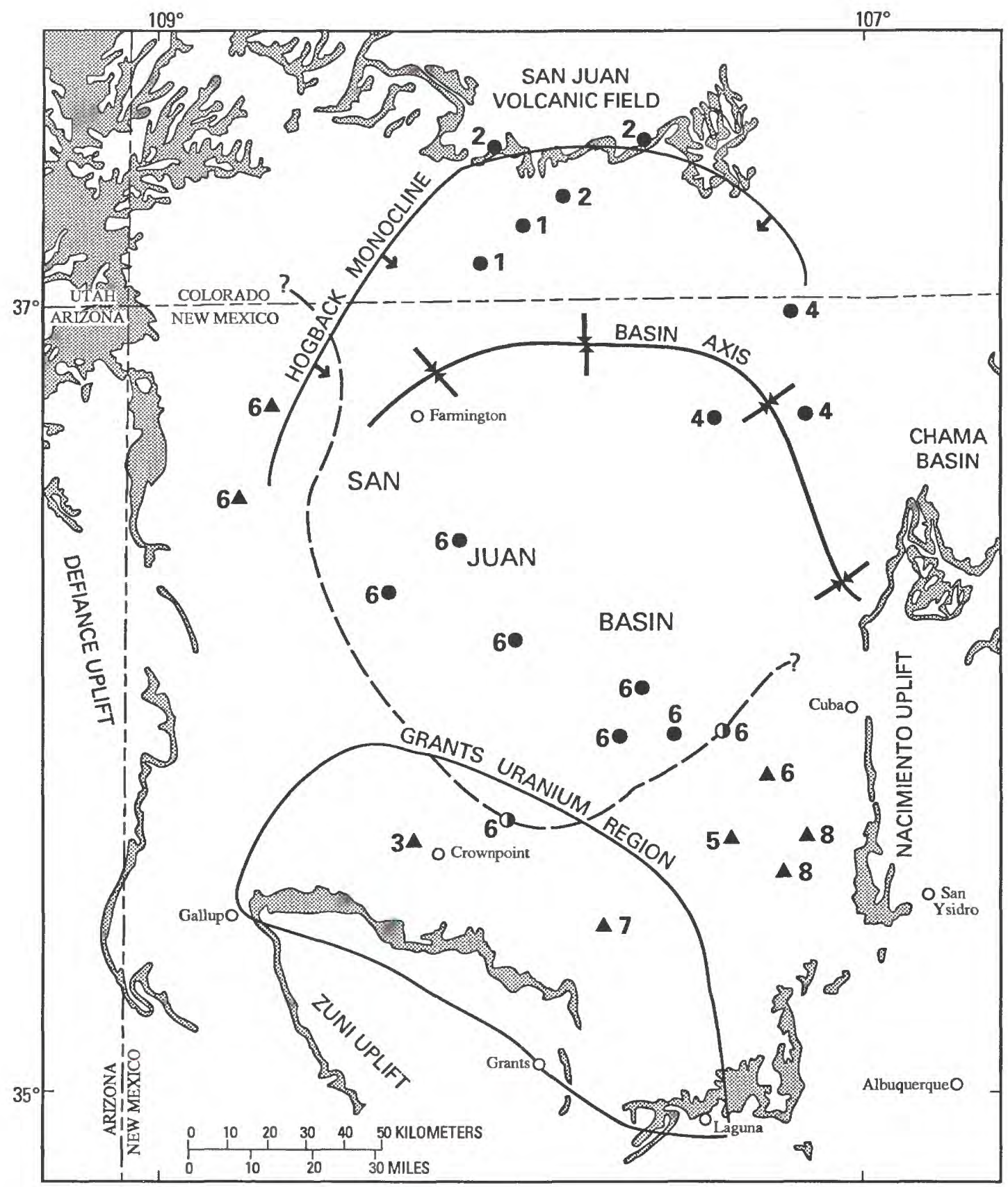

Figure 25. Vitrinite reflectance values for coals in the Upper Cretaceous Dakota Sandstone and Fruitland Formation, San Juan basin. Location of outcrops of Morrison Formation (pattern) also shown. Sources of data: 1, V.F. Nuccio (USGS, written commun., 1988); 2, Rice (1983); 3, N.H. Bostick (USGS, written commun., 1988); 4, Russell (1979); 5, Dow (1982); 6, Keal (1982); 7, Jacobson and others (1985); 8 , Bayliss and Schwarzer $(1987,1988)$. Triangles indicate vitrinite reflectance value of less than 0.8 percent; half-filled circles indicates vitrinite reflectance value of 0.8 percent; solid circles indicate vitrinite reflectance value of greater than 0.8 percent. Dashed line delineates approximate boundary between immature (to the south) and mature (in oil generation window) parts of the Morrison Formation.

dances reflect an increased influx of volcanic material towards the end of Morrison deposition (Hansley, 1986a). The appearance of epidote, abundant staurolite, and sphene along the eastern margin of the basin suggests that a local source area contributed igneous and metamorphic detritus to the basin. The abundance of potassium feldspar, perthitic feldspars, and igneous rock fragments in the area supports this conclusion. 
Influence of Lake T'oo'dichi'

The earliest authigenic phases, such as smectitic clay minerals, silica, zeolites, and feldspars, formed during alteration of the large amount of rhyolitic volcanic ash that was incorporated into the upper part of the Morrison Formation at the time of deposition. Relatively rapid dissolution of the labile ash created alkaline interstitial waters that quickly became saturated with respect to $\mathrm{SiO}_{2}, \mathrm{Na}^{+}$, and $\mathrm{K}^{+}$. Diagenesis in upper sandstones of the Morrison commonly paralleled diagenesis in adjacent tuffaceous, fine-grained lacustrine beds, as alkaline and saline pore waters from the lake sediments escaped into adjacent sands due to salinity gradients and compaction. For example, sandstone beds adjacent to analcimized tuff beds in the Brushy Basin Member at Beclabito dome are cemented with analcime (fig. 13); sandstones adjacent to clinoptilolite-rich, altered tuff beds in the Brushy Basin Member at Senorita Canyon are cemented with clinoptilolite; and sandstones cemented with large albite overgrowths are adjacent to albitized tuff beds at the Durango Hospital section.

Formation of smectite from ash dominated early diagenesis on the southern, western, and eastern margins of the basin where pore waters were fresher. To the north, where Lake T'oo'dichi' waters were more saline and alkaline, early diagenetic products of ash dissolution include zeolites and I/S. Near the center of the lake (Beclabito dome and Durango Hospital sections), high minus cement porosity values $(30-34$ percent in this study) indicate that primary analcime and albite formed from ash dissolution products. This conclusion was also reached by Fishman and others (1986). Analcime in the northernmost cores in the southern part of the basin (fig. 1) coincides with hypothetical extension of the zeolite facies across the basin between outcrops on the western and eastern margins of the basin as mapped by Turner-Peterson (1987).

Smectite becomes increasingly illitic in altered tuff beds toward the center of ancient Lake T'oo'dichi' (Turner-Peterson and others, 1987). Data presented in this report show that smectite in associated sandstones also becomes illitic towards the center of the basin. Turner-Peterson and others (1987) concluded that early precipitation of $\mathrm{I} / \mathrm{S}$ in the Brushy Basin Member was promoted by the extreme alkalinity and salinity of pore waters; thus, the most illitic clays, which are accompanied by authigenic analcime and albite, formed where interstitial waters were the most saline. This interpretation is in contrast to the classical "Gulf Coast" theory in which illitization is considered to be primarily a thermally driven process (Perry and Hower, 1970). In the current study of sandstone diagenesis in the Morrison, illitization of analcime cement where it is in contact with smectitic grain rims (fig. 26) indicates that I/S formed somewhat later than analcime; however, the parallelism between diagenesis in the tuffs and adjacent sandstones strongly suggests that I/S formed during early diagenesis.

Ordering of $\mathbf{I} / \mathrm{S}$ may have occurred slightly later during burial diagenesis. Recent studies have shown that ordering occurs at about 60 percent illite when no smectite layers are bounded by other smectite particles (Nadeau and others, 1985) and involves dissolution and reprecipitation of new clay phases (Whitney and Northrup, 1988). The coexistence of two authigenic mixed-layer I/S phases exhibiting different degrees of ordering in many sandstones of the Morrison Formation is explained by this model.

Preservation of shard textures within analcime cement in sandstones of the Westwater Canyon Member at Senorita Canyon indicates that analcime precipitated during early diagenesis and may have directly replaced volcanic glass. Theoretical chemical activity diagrams indicate that zeolites may form directly from glass if silica activity is high enough (fig. 27). Additional evidence that analcime formed early is the presence of analcimecemented rip-up clasts in fluvial sandstone of the Westwater Canyon Member at Beclabito dome. Although direct formation of analcime from glass may have occurred in some sandstones, the presence of thin smectite or clinoptilolite rims on the shards and clinoptilolite inclusions within the shards suggest that analcime replaced a precursor zeolite (in this case, clinoptilolite). Analcime-replaced shards in the Eocene and Oligocene Vieja Group in Texas were also interpreted to indicate that the analcime replaced clinoptilolite (Walton, 1975). This interpretation corroborates Sheppard's (1971) conclusion that analcime in sedimentary rocks does not form directly from glass. Analcime-filled stylolites and fractures in sandstones at Beclabito dome and at

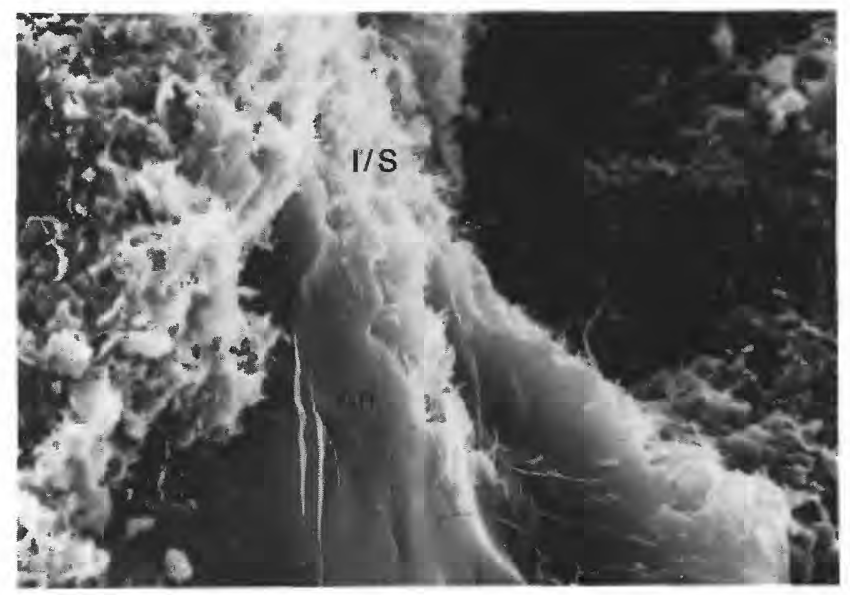

Figure 26. Scanning electron micrograph showing illitic $\mathrm{l} / \mathrm{S}$ that has formed from the margins of analcime cement (An) in a sandstone pore. Length of field, $25 \mu \mathrm{m}$. Sample is from the Westwater Canyon Member at Beclabito dome. 
Senorita Canyon formed somewhat later than the porefilling analcime because major deformation in the region occurred during the Laramide orogeny (Late Cretaceous to early Tertiary) when the Morrison was buried under several hundred meters of Upper Cretaceous sediments.

The precipitation of at least some authigenic potassium feldspar in sandstones of the upper part of the Westwater Canyon Member and in the Brushy Basin Member is related to chemical gradients in Lake T'oo'dichi' (Hansley, 1984; Turner-Peterson, 1987). Where potassium feldspar overgrowths are best developed in outcrop sandstones (such as Oak Springs and Dennison-Bunn), sandstones lie in or under the zeolite and potassium feldspar altered tuff facies of the Brushy Basin Member. Potassic volcanic rock fragments and evolved pore fluids provided intrinsic sources of potassium for the overgrowths, and potassium may have also been supplied by fluids expelled from tuff beds. A potential problem with this interpretation is that the mixed-layer clay minerals in some sandstones that contain potassium feldspar overgrowths, notably those along the Nacimiento uplift, are expandable. If potassium-rich fluids had been in the sandstones, why wasn't smectite illitized? One possibility is that high silica activities $\left(>10^{-2.5}\right)$ in these fluids (confirmed by widespread quartz overgrowths and chalcedony cement) inhibited the formation of illite (Garrels, 1984; Eslinger and Pevear, 1988). Smectite can coexist with potassium

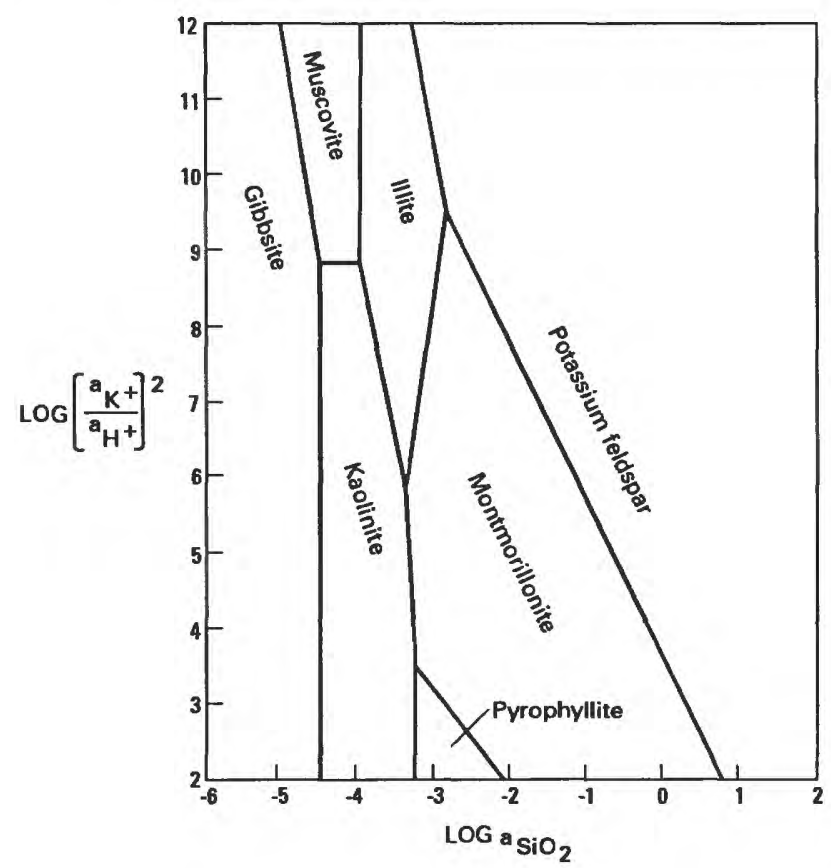

Figure 27. Ion activity diagram showing the relations between some common authigenic minerals in the Morrison Formation. Note that illite and montmorillonite are treated as two separate phases. Modified from Garrels (1984). feldspar at high silica activities (fig. 27). Potassium feldspar forms early as an alteration of tuff beds in Cenozoic saline, alkaline lake deposits; potassium feldspar, which formed indirectly (through intermediate phases) from volcanic ash, has been dated as 60,000 100,000 years old (Hay, 1966). Because they formed in a similar closed basin setting, tuff beds in the Brushy Basin Member that have altered mostly to potassium feldspar and large potassium feldspar overgrowths in associated sandstones are inferred also to have formed during early diagenesis. Potassium feldspar overgrowths that formed later may have precipitated from $\mathrm{K}^{+}$-rich magmatic waters because intrusions in the northwestern San Juan basin are minettes, which are enriched in potassium feldspar (Shoemaker, 1956).

Fishman and others (1986) concluded that albitization of tuffs and sandstones in the Brushy Basin Member was also a very early diagenetic process that took place in the most saline, alkaline facies of Lake T'oo'dichi'. Their conclusion is also partly on the presence of high minus-cement porosity values wherever albite occurs and partly on the cogenetic habit of the albite-quartz-chalcedony assemblage. Early albitization also took place in upper sandstones of the Westwater Canyon Member at Beclabito dome and in upper sandstones of the Recapture Member at the Durango Hospital section; minus-cement porosity values of from 30 to 34 percent in sandstones from these sections indicate that the albite and quartz overgrowths precipitated before compaction. Elevated $\mathrm{Na}^{+}$activity and low water activity in the central part of the lake facilitated early albitization. Analcimic textures of albitized tuff beds (Turner-Peterson, 1987) indicate that albite locally may have been an early product of analcime dissolution, and analcime remnants occur in calcite cement in albitized sandstones at Piedra River. Albite replaces analcime by dehydration and silicification: analcime + silica $=$ albite + water (Liou, 1971). Elevated temperatures and (or) high salinity cause this reaction to proceed to the right, but in the Morrison Formation high salinity was the main factor in causing albite to form because temperatures were close to ambient during early diagenesis. Likewise in the Eocene Green River Formation, albite is inferred to have replaced analcime at the relatively low temperatures of $50-75^{\circ} \mathrm{C}$ because of the high salinities of the pore waters (Hay, 1966).

To estimate the temperature at which authigenic albite in the Morrison Formation formed, albite overgrowths in sandstones of the Brushy Basin Member from the Durango Hospital section were examined for fluid inclusions, but no vapor phases were found in any of the tiny $(<10 \mu \mathrm{m})$ inclusions. If the albite were formed during later diagenesis at elevated temperature, the lack of vapor bubbles could be due to the difficulty in nucleation of vapor bubbles in small inclusions (Roedder, 
1981). Burial history reconstruction (Bond, 1984) shows that maximum temperatures in the Durango area were about $75{ }^{\circ} \mathrm{C}$, high enough to form vapor phases in inclusions. However, textures indicate that the albite formed early, either as a direct precipitate from saline pore waters or as an early replacement of analcime.

The assemblage of authigenic chlorite, potassium feldspar, I/S, and quartz (overgrowths and idiomorphic crystals) commonly observed in sandstones of the Morrison Formation in this study and in the Morrison in the Grants uranium region (Hansley, 1986b) is interpreted to have formed during burial diagenesis. Chlorite precipitation may be explained by the release of $\mathrm{Mg}^{2+}$, $\mathrm{Fe}^{3+}$, and silica during dissolution of random $\mathrm{I} / \mathrm{S}$ and reprecipitation of ordered $\mathrm{I} / \mathrm{S}$. This process provides an explanation for the lack of significant chlorite in samples containing expandable I/S on the western, southern, and eastern margins of the basin.

\section{Alterations Related to Meteoric Water}

Thick (about $5 \mu \mathrm{m}$ ) hematite rims underlying chlorite rims and quartz overgrowths on detrital sand grains in the Morrison Formation along the southern margin of the San Juan basin indicate that early oxidation occurred before the formation of chlorite and quartz overgrowths (Hansley, 1986b). Dissolution of plagioclase grains and precipitation of kaolinite in the uppermost part of the Morrison Formation along the western and southern margins of the basin may have been caused by downward percolation of acidic, oxidizing meteoric water during Early Cretaceous erosion. The occurrence of increasingly higher percentages of detrital plagioclase in the Morrison Formation proceeding downward from the unconformity indicates that the dissolution episode was related to exposure and erosion either during the time represented by the unconformity or slightly later due to corrosive solutions emanating from the Dakota Sandstone. Dissolution of plagioclase and precipitation of kaolinite may have been caused by acidic solutions derived from overlying Dakota coals and carbonaceous shales (Schlee and Moench, 1961; Granger, 1962). This idea remains speculative, however, because neither Flesch (1975) nor Schlee (1957) found an obvious relationship between kaolinite in the Jackpile and the presence of coal in the overlying Dakota Sandstone. Some later oxidation and additional(?) plagioclase dissolution may have occurred during the period late Tertiary to the present (Saucier, 1980), as evidenced by limonite and (or) hematite cement on potassium feldspar and oxidized pyrite in outcrops and shallow sandstones.

\section{Comparison of Diagenetic Interpretations}

Previous diagenetic studies of the Morrison Formation in the southern part of the San Juan basin identified early alteration patterns that were attributed to chemical gradients in Lake T'oo'dichi' (Hansley, 1984, 1986b). Continuation of the same patterns northward into the central and northern parts of the basin supports this conclusion. In previous studies (Whitney and Northrop, 1987), updip movement of warm, deep-basin fluids through the Westwater Canyon Member was inferred by stable isotope data that indicated that cogenetic ordered $\mathrm{I} / \mathrm{S}$ and chlorite precipitated from interstitital fluids at temperatures exceeding $100{ }^{\circ} \mathrm{C}$. Deeply etched garnets occur in precisely the same zone as the isotopically distinct clay minerals (Whitney and others, 1986; Hansley, 1987). In laboratory experiments, warm $\left(>75^{\circ} \mathrm{C}\right)$, oxalic acid-bearing solutions produced systematic etch features on garnets identical to those on naturally etched garnets (Hansley, 1987). Because the Morrison Formation contains garnets throughout the Colorado Plateau (Cadigan, 1967), the present lack of garnets at Durango was apparently caused by complete dissolution of detrital garnets. Burial history data indicate that temperatures during diagenesis in the Durango area were as high as $75^{\circ} \mathrm{C}$; thus, warm pore waters were available to facilitate dissolution of the garnets. Whether organic acids are necessary for dissolution or were involved in dissolution of garnets at Durango is unknown.

A diagenetic mineral assemblage (idiomorphic quartz, adularia, chlorite, ordered I/S) similar to that in the zone of elevated temperature noted above occurs in the upper Salt Wash Member at Beclabito dome and Oak Springs. Oligocene intrusive bodies in the Four Corners area apparently did not elevate formation temperatures because vitrinite reflectance values of Cretaceous rocks just downdip from Morrison Formation outcrops on the western margin of the basin are relatively low. Furthermore, diagenetic maturity varies dramatically in a sequence of tuff beds at Beclabito dome: some beds are zeolitized, some have been altered to potassium feldspar, and others have remained pure smectite (TurnerPeterson, 1987). This diagenetic assemblage may have formed as a result of action by organic acids generated from local concentrations of organic matter within the Salt Wash Member, movement of warm (organic acidbearing?) fluids through the Salt Wash Member, or unknown causes.

In earlier studies of core material in the southern part of the basin, amorphous, epigenetic interstitial organic matter enriched in uranium and other metals was found to be locally abundant (Leventhal, 1980; Hansley, $1986 \mathrm{~b}$ ). During early diagenesis, the organic matter was solubilized by alkaline fluids and was then precipitated in 
sandstone pores. In subsequent diagenetic reactions, bacterially mediated sulfate reduction resulted in precipitation of pyrite and carbonates, as seen in most of the cores from the southern part of the basin. Samples in the present study, however, contain only trace amounts of amorphous organic matter, although evidence of reactions involving organic matter (coffinite, pyrite) exists in several of the cores that were examined. By analogy, detrital organic matter in the Salt Wash Member also influenced diagenetic reactions in that hydrolysis of volcanic ash created alkaline waters favorable for leaching soluble organic matter from decaying plant material. In the vicinity of organic matter (detrital or epigenetic), therefore, chemical reactions were facilitated by the release of soluble organic complexes during low-temperature bacterial metabolism. Soluble organic complexes have been shown in experiments (Surdam and Crossey, 1985) and in natural settings (Bennett and Siegel, 1987) to dramatically increase the solubility of chemical species, including silica. This process may explain the abundance of potassium feldspar and quartz overgrowths in the vicinity of ore zones.

The alteration patterns in the Jackpile Sandstone Member reflect basinwide depositional and diagenetic patterns. Albitization at the base of the Jackpile is a result of saline fluids migrating into basal sandstones from the playa facies of the Brushy Basin Member, and kaolinization of the upper part of the Jackpile was caused by fluids migrating downward during exposure in the Early Cretaceous Epoch. Adams and others (1978) reached the same conclusions during their study of diagenesis in the Jackpile Sandstone Member.

\section{CHEMISTRY}

During early diagenesis of the Morrison Formation, interstitial waters were moderately alkaline (pH about 8.5) due to the dissolution of volcanic ash. Formation of early authigenic phases, such as smectite and zeolites, was controlled by several variables including the activities of $\mathrm{Na}^{+}, \mathrm{K}^{+}, \mathrm{H}_{4} \mathrm{SiO}_{4}{ }^{0}$, and $\mathrm{Al}(\mathrm{OH})_{4}{ }^{-}, \mathrm{pH}$, and total ionic strength of pore waters. Of these, silicic acid $\left(\mathrm{H}_{4} \mathrm{SiO}_{4}{ }^{0}\right)$ and aluminate ion $\left(\mathrm{AlOH}_{4}{ }^{-}\right)$activities are the most important because most early diagenetic phases were aluminosilicates. Aluminate ion solubility increases dramatically above a $\mathrm{pH}$ of 7 , whereas silica solubility does not increase markedly until a pH of 9.9 at $25^{\circ} \mathrm{C}$ (Drever, 1982; Donahoe and Liou, 1985). The solubility of aluminum, therefore, increases more rapidly than the solubility of silica between $\mathrm{pH} 7$ and 9.9. Above pH 9.9, silica solubility becomes a dominant control of the $\mathrm{Si} / \mathrm{Al}$ ratios in aluminosilicate minerals. Aluminate activity thus was probably a major factor in diagenetic reactions because $\mathrm{pH}$ values were almost certainly below
9.9 except in the most saline, alkaline conditions near the center of the lake. In addition, the presence of soluble organic matter in early interstitial waters further increased the solubility of aluminum because of the excellent complexing ability of the organics. Aluminate ion concentration is considered to be a constant in many published chemical reactions, a practice that seems unrealistic considering the normal $\mathrm{pH}$ range of most sediments.

The solubility of silica in alkaline solutions is controlled by the solubility of amorphous silica rather than by that of quartz (Garrels and Christ, 1965). It follows, therefore, that in Cenozoic saline/alkaline lacustrine deposits zeolites and glass are associated with amorphous silica (such as opal) (Hay, 1966). Opal has not been found in Morrison sediments because in the time elapsed since early diagenesis it would have converted to a more stable, crystalline form of silica such as quartz or chert. The high silica activity in tuffaceous sediments may explain the occurrence of zeolites in some samples without significant clay mineral development (Boles and Surdam, 1979).

A puzzling aspect of diagenetic assemblages in sandstones of the upper Morrison sandstones and associated fine-grained beds, in view of the alkaline chemistry, is the paucity of early carbonate minerals. Cenozoic saline, alkaline lakes and playa-lake facies of the Eocene Green River Formation have abundant authigenic carbonate and bicarbonate minerals (Milton and Eugster, 1959). The lack of preserved authigenic carbonate minerals in the Morrison Formation is partly due to replacement by later diagenetic phases because in many samples remnants of carbonate cement are present

Organic complexes are very soluble in moderately alkaline water. Therefore, during early diagenesis, when $\mathrm{pH}$ values were buffered to moderately basic values by the dissolution of volcanic ash, the concentration of organics in solution was locally high, particularly where detrital organic matter was present. During later diagenesis, locally elevated temperatures $\left(>75{ }^{\circ} \mathrm{C}\right)$ again favored the solubility of organic complexes, and the resultant acid pore waters (combined with the excellent complexing ability of organic acid anions) caused dissolution of framework grains and cements.

\section{KINETIC MODEL FOR DIAGENESIS}

Dibble and Tiller (1981) stated that "chemical equilibrium ${ }^{* * *}$ is least likely to be attained in sedimentary rocks containing volcanic glass." Thus, diagenetic reactions in the Morrison during early diagenesis were mostly kinetically, rather than equilibrium controlled (Senderov, 1983) because at the time of deposition the Morrison Formation contained an abundance of unstable volcanic material. Dissolution of 
volcanic glass was rapid relative to formation of alteration products; therefore, as glass dissolved, interstitial solutions quickly became supersaturated with respect to many mineral phases. The phases that precipitated under conditions of supersaturation were metastable, fastgrowing phases such as smectite, aluminosilicate gels, and disordered zeolites and feldspars (Dibble and Tiller, 1981). The thermodynamic drive of water-rock systems is toward the lowest free energy state (Garrels and Christ, 1965). The total free energy of a system is decreased most rapidly by precipitation of fast-growing, metastable phases rather than by formation of slow-growing, stable phases (Dibble and Tiller, 1981). Ordered feldspars and I/S formed somewhat later than earliest diagenesis through transformation of earlier phases in conditions of lower supersaturation rather than directly from dissolution of glass. These phases formed earlier, however, than in normal marine sediments because of the favorable chemistry of interstitial waters in the upper part of the Morrison Formation.

\section{SUMMARY AND CONCLUSIONS}

Widespread preservation of vitric textures in sandstone matrix and of early zeolite cements in primary pores for 100 million years or more is remarkable. The dissolution of volcanic ash coupled with chemical gradients in Lake T'oo'dichi' were the major variables that determined the composition of authigenic mineral phases in the upper members of the Morrison Formation (descending: Jackpile Sandstone, Brushy Basin, and upper part of the Westwater Canyon Members) at a particular locality in the basin during the first stages of diagenesis. Early diagenetic alterations in the upper part of the Morrison Formation in the San Juan basin are well preserved in distinct, concentric patterns that were relatively unaffected by subsequent burial history as indicated by the lack of correlation between vitrinite reflectance values and diagenetic patterns. Later diagenesis in sandstones was influenced by elevated thermal gradients caused by burial diagenesis, by updip migration of warm waters from deeper parts of the basin, by local influence of organic acids derived from the diagenesis of organic matter, and by downdip migration of meteoric waters due to uplift of recharge areas. Sandstones in the lower members, the Salt Wash and Recapture, contain predominantly early calcite and (or) anhydrite cements and exhibit little grain alteration except where uranium enrichment is found.

In the closed-basin environment of high ionic strength and alkalinity that existed near the center of Lake T'oo'dichi' in late Morrison time, the interval between formation of metastable and stable phases was foreshortened. The first authigenic phases to form were those that grew the fastest at ambient temperatures and pressures (such as disordered zeolites, feldspars, and clay minerals), but these phases were not the most stable thermodynamically. In some sandstones near the center of the lake, disordered(?) albite and quartz overgrowths apparently precipitated directly from solution. In other sandstones, dissolution of metastable phases such as analcime and random I/S was followed by precipitation of stable phases such as albite and ordered I/S in response to favorable chemical conditions well before maximum burial and diagenetic temperatures were achieved.

\section{REFERENCES CITED}

Adams, S.S., Curtis, H.S., and Hafen, P.L., 1974, Alteration of detrital magnetite-ilmenite in continental sandstones of the Morrison Formation, New Mexico, in Formation of uranium deposits: Vienna, International Atomic Energy Agency Proceedings IAEA-SM-183/36, p. 219-253.

Adams, S.S., Curtis, H.S., Hafen, P.L., and Salek-Nejad, H., 1978, Interpretation of postdepositional processes related to the formation of the Jackpile-Paguate uranium deposit, northwest New Mexico: Economic Geology, v. 73 , no. 8 , p. $1635-1654$.

Adams, S.S., and Saucier, A.E., 1981, Geology and recognition criteria for uraniferous humate deposits, Grants uranium region, New Mexico: U.S. Department of Energy Report GJBX-2(81), 225 p.

American Association of Petroleum Geologists and U.S. Geological Survey, 1975, Geothermal gradient map of North America: Geothermal Survey of North America Subcommittee of American Association of Petroleum Geologists Research Committee, scale 1:5,000,000.

Aubrey, W.M., 1986, The nature of the Dakota-Morrison boundary, southeastern San Juan basin, in TurnerPeterson, C.E., Santos, E.S., and Fishman, N.S., eds., A basin analysis case study; the Morrison Formation, Grants uranium region, New Mexico: American Association of Petroleum Geologists Studies in Geology 22, p. 93-104.

Austin, S.R. 1963, Alteration of the Morrison sandstone, in Kelley, V.C., compiler, Geology and technology of the Grants uranium region: New Mexico Bureau of Mines and Mineral Resources Memoir 15, p. 38-44.

1980, Dissolution and authigenesis of feldspars, in Rautman, C.A., compiler, Geology and mineral technology of the Grants uranium region 1979: New Mexico Bureau of Mines and Mineral Resources Memoir 38, p. 107-115.

Bayliss, G.S , and Schwarzer, R.R., 1987, Hydrocarbon source rock evaluation of EPNG Elliott State, Sec. 36, T19N, R2W, Sandoval County, New Mexico: New Mexico Bureau of Mines and Mineral Resources Open-File Report 298, 14 p.

1988, Hydrocarbon source rock evaluation of Shell Oil No. 41 Wright, Sec. 26, T17N, R3W, Sandoval County, New Mexico: New Mexico Bureau of Mines and Mineral Resources Open-File Report 329, 14 p.

Bell, T.E., 1983, Deposition and diagenesis of the Brushy Basin and upper Westwater Canyon Members of the Morrison 
Formation in northwest New Mexico and its relationship to uranium mineralization: Berkeley, Calif., University of California, Ph.D. thesis, 102 p.

1986, Deposition and diagenesis in the Brushy Basin Member and upper part of the Westwater Canyon Member of the Morrison Formation, San Juan Basin, New Mexico, in Turner-Peterson, C.E., Santos, E.S., and Fishman, N.S., eds., A basin analysis case study; the Morrison Formation, Grants uranium region, New Mexico: American Association of Petroleum Geologists Studies in Geology 22, p. 77-92.

Bennett, P., and Siegel, D.I., 1987, Increased solubility of quartz in water due to complexing by organic compounds: Nature, v. 326 , no. 6114 , p. 684-686.

Boles, J.R., and Surdam, R.C., 1979, Diagenesis of volcanogenic sediments in a Tertiary saline lake; Wagon Bed Formation, Wyoming: American Journal of Science, v. 279 , p. $832-853$.

Bond, W.A., 1984, Application of Lopatin's method to determine burial history, evolution of the geothermal gradient, and timing of hydrocarbon generation in Cretaceous source rocks in the San Juan basin, northwestern New Mexico and southwestern Colorado, in Woodward, Jane, Meissner, F.F., and Clayton, J.L., eds., Hydrocarbon source rocks of the greater Rocky Mountain region: Rocky Mountain Association of Geologists, p. 433-447.

Brown, G., and Brindley, G.W., 1980, X-ray diffraction procedures for clay mineral identifications, in Brindley, G.W., and Brown, G., eds., 1980, Crystal structures of clay minerals and their X-ray identification: Mineralogical Society of London Monograph 5, p. 305-359.

Cadigan, R.A., 1967, Petrology of the Morrison Formation in the Colorado Plateau region: U.S. Geological Survey Professional Paper 556, 113 p.

Clarkson, G., and Reiter, M., 1987, The thermal regime of the San Juan basin since Late Cretaceous times and its relationship to San Juan Mountains thermal sources: Journal of Volcanology and Geothermal Research, v. 31, p. 217-237.

Condon, S.M., and Peterson, Fred, 1986, Stratigraphy of Middle and Upper Jurassic rocks of the San Juan basin; historical perspective, current ideas, and remaining problems, in Turner-Peterson, C.E., Santos, E.S., and Fishman, N.S., eds., A basin analysis case study; the Morrison Formation, Grants uranium region, New Mexico: American Association of Petroleum Geologists Studies in Geology 22, p. 7-26.

Cooley, M.E., and Davidson, E.S., 1963, The Mogollon highlands; their influence on Mesozoic and Cenozoic erosion and sedimentation: Arizona Geological Society Digest, v. 6, p. 7-35.

Craig, L.C., Holmes, C.N., Cadigan, R.A., Freeman, V.L., Mullens, T.E., and Weir, G.W., 1955, Stratigraphy of the Morrison and related formations, Colorado Plateau region, a preliminary report: U.S. Geological Survey Bulletin 1009-E, p. 125-168.

Dibble, W.E., Jr., and Tiller, W.A., 1981, Kinetic model of zeolite paragenesis in tuffaceous sediments: Clays and Clay Minerals, v. 29, no. 3, p. 323-330.
Dickinson, W.R., 1981, Plate tectonic evolution of the southern Cordillera, in Dickinson, W.R., and Payne, W.E., eds., Relations of tectonics to ore deposits in the southern Cordillera: Arizona Geological Society Digest, v. 14, p. 113-135.

Donahoe, R.J., and Liou, J.G., 1985, An experimental study of the process of zeolite formation: Geochemica et Cosmochimica Acta, v. 49, p. 2349-2360.

Dow, W.G., 1982, Geochemical evaluation of the James P. Dunigan No. 1 Santa Fe, McKinley County, New Mexico: New Mexico Bureau of Mines and Mineral Resources Open-File Report 267, 25 p.

Drever, J.I., 1982, The geochemistry of natural waters: Englewood Cliffs, N.J., Prentice-Hall, 388 p.

Eslinger, Eric, and Pevear, David, 1988, Clay minerals for petroleum geologists and engineers: Society of Economic Paleontologists and Mineralogists Short Course Notes $22,413 \mathrm{p}$.

Fishman, N.S., Turner-Peterson, C.E., and Hay, R.L., 1986, Authigenic albite in the Upper Jurassic Morrison Formation; evidence for early diagenetic formation: Society of Economic Paleontologists and Mineralogists, Annual Midyear Meeting, Abstracts, v. 3, p. 37.

Flesch, G.A., 1975, Stratigraphy, sedimentology, and environments of deposition of the Morrison (Upper Jurassic) Formation, Ojito Spring quadrangle, Sandoval County, New Mexico: Albuquerque, N. Mex., University of New Mexico, M.S. thesis, 106 p.

Folk, R.L., 1974, Petrology of sedimentary rocks: Austin, Tex., Hemphill's, 182 p.

Garrels, R.M., 1984, Montmorillonite/illite stability diagrams: Clays and Clay Minerals, v. 32, no. 1, p. 161-166.

Garrels, R.M., and Christ, C.L., 1965, Solutions, minerals, and equilibria: New York, Harper and Row, 450 p.

Goldhaber, M.B., Hemingway, B.S., Mohaghegi, Ali, Reynolds, R.L., and Northrop, H.R., 1987, Origin of coffinite in sedimentary rocks by a sequential adsorption-reduction mechanism: Societe Francaise de Mineralogie et de Cristallographie Bulletin de Mineralogie, v. 110, p. 131-144.

Granger, H.C., 1962, Clays in the Morrison Formation and their spatial relation to the uranium deposits at Ambrosia Lake, New Mexico, in Geological Survey Research 1962: U.S. Geological Survey Professional Paper 450-D, p. D15-D20.

Grant, Keith, and Owen, D.W., 1974, The Dakota Sandstone (Cretaceous) of the southern part of the Chama basin, New Mexico; a preliminary report on its stratigraphy, paleontology, and sedimentology, in Siemers, C.T., ed., Central-northern New Mexico: New Mexico Geological Society Silver Anniversary Guidebook, p. 239-249.

Hamilton, Warren, 1978, Mesozoic tectonics of the western United States, in Howell, D.G., and McDougall, K.A., eds., Mesozoic paleogeography of the western United States: Pacific Section, Society of Economic Paleontologists and Mineralogists, p. 33-70. 
Hansley, P.L., 1984, Feldspar alteration patterns in the Upper Jurassic Morrison Formation, northwestern New Mexico: Society of Economic Paleontologists and Mineralogists, National Midyear Meeting, 1st, Technical Program, p. 37.

1986a, Relationship of detrital, nonopaque heavy minerals to diagenesis and provenance of the Morrison Formation, southwestern San Juan basin, New Mexico, in Turner-Peterson, C.E., Santos, E.S., and Fishman, N.S., eds., A basin analysis case study; the Morrison Formation, Grants uranium region, New Mexico: American Association of Petroleum Geologists Studies in Geology 22, p. 257-276.

1986b, Regional diagenetic trends and uranium mineralization in the Morrison Formation across the Grants uranium region, in Turner-Peterson, C.E., Santos, E.S., and Fishman, N.S., eds., A basin analysis case study; the Morrison Formation, Grants uranium region, New Mexico: American Association of Petroleum Geologists Studies in Geology 22, p. 277-302.

1987, Petrologic and experimental evidence for the etching of garnets by organic acids in the Upper Jurassic Morrison Formation, northwestern New Mexico: Journal of Sedimentary Petrology, v. 57, no. 4, p. 666-681.

Haun, J.D., and Weimer, R.J., 1960, Cretaceous stratigraphy of Colorado, in Weimer, R.J., and Haun, J.D., eds., Guide to the geology of Colorado: Geological Society of America, Rocky Mountain Association of Geologists, and Colorado Scientific Society, p. 58-65.

Hay, R.L., 1966, Zeolites and zeolitic reactions in sedimentary rocks: Geological Society of America Special Paper 85, $123 \mathrm{p}$.

Hicks, R.T., 1981, Diagenesis of the Westwater Canyon Member, Morrison Formation, East Chaco Canyon drilling project, New Mexico: Albuquerque, N. Mex., University of New Mexico, M.S. thesis, 131 p.

Hilpert, L.S., and Moench, R.H., 1960, Uranium deposits of the southern part of the San Juan basin, New Mexico: Economic Geology, v. 55, no. 3, p. 429-464.

Jacobson, S.R., Saxton, J.D., and Tully, K.M., 1985, Organic geochemical analyses of Superior Oil Co. No. 1-14 San Mateo Well, McKinley County, New Mexico: New Mexico Bureau of Mines and Mineral Resources OpenFile Report 260, 16 p.

Kastner, Miriam, 1971, Authigenic feldspar in carbonate rocks: American Mineralogist, v. 56, p. 1403-1442.

Keal, J.E., 1982, Geochemical analysis of the Brinkerhoff Drilling Co. No. 1 Cabezon-Government (Sandoval County), Great Western Drilling Co. No. 1 HospahSanta Fe (McKinley County), Magnolia Petroleum Corp. No. 1 Hutchinson-Federal (Sandoval County), Union Oil Co. of California No. 1 M-13 USA (Sandoval County), Sun Oil Co. No. 1 Navajo Lands (San Juan County), Apache Corp. No. 1 Foshay (San Juan County), Shell Oil Co. No. 113-17 Carson 'Unit (San Juan County), Skelly Oil Co. No. 1 Navajo O (San Juan County), Texaco, Inc. No. 1 Navajo Al (San Juan County), Amerada Petroleum Corp. No. 1 Navajo Tract 20 (San Juan County), and
Delhi Oil Corp. No. 4 Ute (San Juan County) Wells, New Mexico: New Mexico Bureau of Mines and Mineral Resources Open-File Report 268, 117 p.

Kelley, V.C., 1951, Tectonics of the San Juan basin, in Guidebook of the south and west sides of the San Juan basin, New Mexico and Arizona: New Mexico Geological Society, Field Conference, 2nd, p. 124-131.

Kelley, V.C., and Clinton, N.J., 1960, Fracture systems and tectonic elements of the Colorado Plateau: University of New Mexico Publications in Geology 6, 104 p.

Kirk, A.R., and Condon, S.M., 1986, Structural control of sedimentation patterns and the distribution of uranium deposits in the Westwater Canyon Member of the Morrison Formation, northwestern New Mexico; a subsurface study, in Turner-Peterson, C.E., Santos, E.S., and Fishman, N.S., eds., A basin analysis case study; the Morrison Formation, Grants uranium region, New Mexico: American Association of Petroleum Geologists Studies in Geology 22, p. 105-144.

Leventhal, J.S., 1980, Organic geochemistry and uranium in Grants mineral belt, in Rautman, C.A., compiler, Geology and mineral technology of the Grants uranium region 1979: New Mexico Bureau of Mines and Mineral Resources, v. 38, p. 75-85.

Liou, J.G., 1971, Analcime equilibria: Lithos, v. 4, p. 389-402.

Lowy, R.M., 1982, Provenance and sediment-dispersal patterns, Westwater Canyon sandstones, western San Juan basin, New Mexico: Albuquerque, N. Mex., University of New Mexico, M.S. thesis, 203 p.

Ludwig, K.R., Simmons, K.R., and Webster, J.D., 1984, U-Pb isotope systematics and apparent ages of uranium ores, Ambrosia Lake and Smith Lake districts, Grants mineral belt, New Mexico: Economic Geology, v. 79, p. 322-337.

Martinez, Ruben, 1979, Provenance study of the Westwater Canyon and Brushy Basin Members of the Morrison Formation between Gallup and Laguna, New Mexico: Albuquerque, N. Mex., University of New Mexico, Ph.D. thesis, $58 \mathrm{p}$.

Milton, Charles, and Eugster, H.P., 1959, Mineral assemblages of the Green River Formation: Research in Geochemistry, v. 1, p. 118-150.

Moench, R.H., and Schlee, J.S., 1967, Geology and uranium deposits of the Laguna district, New Mexico: U.S. Geological Survey Professional Paper 519, 117 p.

Nadeau, P.H., Wilson, M.J., McHardy, W.J., and Tait, J.M., 1985, The conversion of smectite to illite during diagenesis; evidence from some illitic clays from bentonites and sandstones: Mineralogical Magazine, v. 49, p. 393-400.

Nash, J.T., 1968, Uranium deposits in the Jackpile Sandstone, New Mexico: Economic Geology, v. 63, p. 737-750.

Nuccio, V.F., and Johnson, R.C., 1988, Surface vitrinitereflectance map of the Uinta, Piceance, and Eagle basins area, Utah and Colorado: U.S. Geological Survey Map MF-2008-B, 22 p.

Owen, D.W., Walters, L.J., Jr., and Beck, R.G., 1984, The Jackpile Sandstone Member of the Morrison Formation in west-central New Mexico; a formal definition: New Mexico Geology, v. 6, no. 3, p. 45-52. 
Perry, E., and Hower, J., 1970, Burial diagenesis in Gulf Coast pelitic sediments: Clays and Clay Minerals, v. 13, p. $165-178$.

Peterson, Fred, 1984, Fluvial sedimentation on a quivering craton; influence of slight crustal movements on fluvial processes, Upper Jurassic Morrison Formation, western Colorado Plateau: Sedimentary Geology, v. 38, no. 1/4, p. 21-49.

Reynolds, R.C., 1980, Interstratified clay minerals in Brindley, G.W., and Brown, G., eds., 1980, Crystal structures of clay minerals and their X-ray identification: Mineralogical Society of London, Monograph 5, p. 249-304.

Reynolds, R.L., Fishman, N.S., Scott, J.H., and Hudson, M.R., 1986, Iron-titanium oxide minerals and magnetic susceptibility anomalies in the Mariano Lake-Lake Valley cores; constraints on conditions of uranium mineralization in the Morrison Formation, San Juan basin, New Mexico, in Turner-Peterson, C.E., Santos, E.S., and Fishman, N.S., eds., A basin analysis case study; the Morrison Formation, Grants uranium region, New Mexico: American Association of Petroleum Geologists Studies in Geology 22, p. 303-314.

Rice, D.D., 1983, Relation of natural gas composition to thermal maturity and source rock type in San Juan basin, northwestern New Mexico and southwestern Colorado: American Association of Petroleum Geologists Bulletin, v. 87 , no. 8 , p. $1199-1218$.

Ridgely, J.L, 1977, Stratigraphy and depositional environments of Jurassic-Cretaceous sedimentary rocks in the southwest part of the Chama basin, New Mexico, in Fassett, J.E., ed., San Juan Basin III: New Mexico Geological Society Field Conference, 28th, Guidebook, p. 153-158.

Roedder, Edwin, 1981, Origins of fluid inclusions and changes that occur after trapping, in Hollister, L.S., and Crawford, M.L., eds., Fluid inclusions; applications to petrology: Mineralogical Association of Canada Short Course, p. 101-137.

Ruetschilling, R.L., 1973, Structure and stratigraphy of the San Ysidro quadrangle, Sandoval County, New Mexico: Albuquerque, N. Mex., University of New Mexico, M.S. thesis, $79 \mathrm{p}$.

Russell, J.A., 1979, Vitrinite reflectance and kerogen analyses of the Great Western Drilling Co. No. 1 Hospah-Santa Fe (McKinley County), Continental Oil Company No. 1 South Dulce (Rio Arriba County), El Paso Natural Gas Company No. 50 San Juan Unit 29-5 (Rio Arriba County), and Pan American Petroleum Corporation No. 1 Pagosa Jicarrilla (Rio Arriba County) Wells, New Mexico: New Mexico Bureau of Mines and Mineral Resources Open-File Report 265, 9 p.

Santos, E.S., 1975, Lithology and uranium potential of Jurassic formations in the San Ysidro-Cuba and Majors Ranch areas, northwestern New Mexico: U.S. Geological Survey Bulletin 1329, 22 p.

Santos, E.S., and Turner-Peterson, C.E., 1986, Tectonic setting of the San Juan basin in the Jurassic, in Turner-Peterson, C.E., Santos, E.S., and Fishman, N.S., eds., A basin analysis case study; the Morrison Formation, Grants uranium region, New Mexico: American Association of Petroleum Geologists Studies in Geology 22, p. 27-34.

Saucier, A.E., 1974, Stratigraphy and uranium potential of the Burro Canyon Formation in the southern Chama basin, New Mexico, in Siemers, C.T., ed., Central-northern New Mexico: New Mexico Geological Society Silver Anniversary Guidebook, p. 211-217.

1980, Tertiary oxidation in the Westwater Canyon Member of the Morrison Formation, in Rautman, C.A., compiler, Geology and mineral technology of the Grants uranium region 1979: New Mexico Bureau of Mines and Mineral Resources Memoir 38, p. 151-157.

Schlee, J.S., 1957, Petrology of the Jackpile sandstone, New Mexico: Geological Society of America Bulletin, v. 68, p. 1793.

Schlee, J.S., and Moench, R.H., 1961, Properties and genesis of "Jackpile" sandstone, Laguna, New Mexico, in Peterson, J.A., and Osmond, J.C., eds., Geometry of sandstone bodies: American Association of Petroleum Geologists, p. $135-150$.

Schmitt, L.J., 1982, Petrographic study of sandstones from measured sections of the Morrison Formation and related units, southwestern San Juan basin, New Mexico: U.S. Geological Survey Open-File Report 82-991, 58 p.

Senderov, E.E., 1983, Metastable systems in zeolite formation: Geochemistry International, v. 20, no. 6, p. 66-74.

Sheppard, R.A., 1971, Zeolites in sedimentary deposits of the United States; a review, in Flanigen, E.M., and Sand, L.B., eds., Molecular sieve zeolites I: American Chemical Society Advances in Chemistry Series 101, p. 279-310.

Shoemaker, E.M., 1956, Occurrence of uranium in diatremes on the Navajo and Hopi Reservations, Arizona, New Mexico, and Utah, in Page, L.R., Stocking, H.E., and Smith, H.B., compilers, Contributions to the geology of uranium and thorium by the United States Geological Survey and Atomic Energy Commission for the United Nations International Conference on Peaceful Uses of Atomic Energy, Geneva, Switzerland 1955: U. S. Geological Survey Professional Paper 300, p. 179-185.

Steele, B.A., 1984a, Preliminary report on the petrography of the Upper Jurassic Morrison Formation, Mariano LakeLake Valley Drilling Project, McKinley County, New Mexico: U.S. Geological Survey Open-File Report 84-170, 40 p.

$1984 \mathrm{~b}$, Preliminary report on the petrography of the Upper Jurassic Morrison Formation from four surface sections, southwestern San Juan Basin, McKinley County, New Mexico: U.S. Geological Survey Open-File Report 84-780, 29 p.

Surdam, R.C, and Crossey, L.J., 1985, Mechanisms of organic/ inorganic interactions in ss/sh sequences, in Relationship of organic matter and mineral diagenesis: Society of Economic Paleontologists and Mineralogists Short Course 17, p. 177-279.

Turner-Peterson, C.E., 1986, Fluvial sedimentology of a major uranium-bearing sandstone; a study of the Westwater Canyon Member of the Morrison Formation, San Juan basin, New Mexico, in Turner-Peterson, C.E., Santos, E.S., and Fishman, N.S., eds., A basin analysis case study; 
the Morrison Formation, Grants uranium region, New Mexico: American Association of Petroleum Geologists Studies in Geology 22, p. 47-76.

1987, Sedimentology of the Westwater Canyon and Brushy Basin Members, Upper Jurassic Morrison Formation, Colorado Plateau, and relationship to uranium mineralization: Boulder, Colo., University of Colorado, Ph.D. thesis, $168 \mathrm{p}$.

Turner-Peterson, C.E., and Fishman, N.S., 1986, Geologic synthesis and genetic models for uranium mineralization in the Morrison Formation, Grants uranium region, New Mexico, in Turner-Peterson, C.E., Santos, E.S., and Fishman, N.S., eds., A basin analysis case study; the Morrison Formation, Grants uranium region, New Mexico: American Association of Petroleum Geologists Studies in Geology 22, p. 357-388.

Turner-Peterson, C.E., Fishman, N.S., and Owen, D.E., 1987, Zonation of clay minerals in a Jurassic playa-lake setting; a case for low-temperature formation of illite: Society of Economic Paleontologists and Mineralogists, Annual Midyear Meeting, Abstracts, v. 4, p. 85.

Turner-Peterson, C.E., Santos, E.S., and Fishman, N.S., eds., 1986, A basin analysis case study; the Morrison Formation, Grants uranium region, New Mexico: American Association of Petroleum Geologists Studies in Geology 22, 388 p.

Walker, T.R., 1984, 1984 SEPM Presidential address; diagenetic albitization of potassium feldspar in arkosic sandstones: Journal of Sedimentary Petrology, v. 54, no. 1 , p. 3-16.

Walton, A.W., 1975, Zeolitic diagenesis in Oligocene volcanic sediments, Trans-Pecos, Texas: Geological Society of America Bulletin, v. 86, p. 615-624.

Waples, D.W., 1985, Geochemistry in petroleum exploration: Boston, International Human Resources Development Corporation, 232 p.
Waters, A.C., and Granger, H.C., 1953, Volcanic debris in uraniferous sandstones, and its possible bearing on the origin and precipitation of uranium: U.S. Geological Survey Circular 224, 26 p.

Weeks, A.D., and Garrels, R.M., 1959, Geologic setting of Colorado Plateau ores, in Garrels, R.M., and Larson, E.S., 3rd, compilers, Geochemistry and mineralogy of Colorado Plateau ores: U.S. Geological Survey Professional Paper 320, p. 3-11.

Whitney, C.G., 1986, Petrology of clay minerals in the subsurface Morrison Formation near Crownpoint, southern San Juan basin, New Mexico; an interim report, in Turner-Peterson, C.E., Santos, E.S., and Fishman, N.S., eds., A basin analysis case study; the Morrison Formation, Grants uranium region, New Mexico: American Association of Petroleum Geologists Studies in Geology 22, p. 315-330.

1988, Experimental investigation of the smectite to illite reaction; dual reaction mechanisms and oxygen-iostope systematics: American Mineralogist, v. 73, p. 77-90.

Whitney, C.G., and Northrop, H.R, 1987, Diagenesis and fluid flow in the San Juan basin, New Mexico; regional zonation in the mineralogy and stable isotope composition of clay minerals in sandstone: American Journal of Science, v. 287, p. 353-382.

Whitney, C.G., Northrop, H.R., and Hansley, P.L., 1986, The use of mineral alteration patterns and stable isotope compositions to infer a paleohydrologic regime, in Carter, L.M.H., ed., USGS Research on Energy Resources-1986, Program and Abstracts: U.S. Geological Survey Circular 974, p. 73-74.

Williams, Howell, Turner, F.J., and Gilbert, C.M., 1954, Petrography: San Francisco, W.H. Freeman, 406 p.

Woodward, L.A., and Schumacher, O.L., 1973, Morrison Formation of the southeastern San Juan basin, New Mexico: New Mexico State Bureau of Mines and Mineral Resources Circular 129, 7 p. 
s 


\section{SELECTED SERIES OF U.S. GEOLOGICAL SURVEY PUBLICATIONS}

\section{Periodicals}

Earthquakes \& Volcanoes (issued bimonthly).

Preliminary Determination of Epicenters (issued monthly).

\section{Technical Books and Reports}

Professional Papers are mainly comprehensive scientific reports of wide and lasting interest and importance to professional scientists and engineers. Included are reports on the results of resource studies and of topographic, hydrologic, and geologic investigations. They also include collections of related papers addressing different aspects of a single scientific topic.

Bulletins contain significant data and interpretations that are of lasting scientific interest but are generally more limited in scope or geographic coverage than Professional Papers. They include the results of resource studies and of geologic and topographic investigations; as well as collections of short papers related to a specific topic.

Water-Supply Papers are comprehensive reports that present significant interpretive results of hydrologic investigations of wide interest to professional geologists, hydrologists, and engineers. The series covers investigations in all phases of hydrology, including hydrogeology, availability of water, quality of water, and use of water.

Circulars present administrative information or important scientific information of wide popular interest in a format designed for distribution at no cost to the public. Information is usually of short-term interest.

Water-Resources Investigations Reports are papers of an interpretive nature made available to the public outside the formal USGS publications series. Copies are reproduced on request unlike formal USGS publications, and they are also available for public inspection at depositories indicated in USGS catalogs.

Open-File Reports include unpublished manuscript reports, maps, and other material that are made available for public consultation at depositories. They are a nonpermanent form of publication that may be cited in other publications as sources of information.

\section{Maps}

Geologic Quadrangle Maps are multicolor geologic maps on topographic bases in $71 / 2$ - or 15 -minute quadrangle formats (scales mainly $1: 24,000$ or $1: 62,500$ ) showing bedrock, surficial, or engineering geology. Maps generally include brief texts; some maps include structure and columnar sections only.

Geophysical Investigations Maps are on topographic or planimetric bases at various scales; they show results of surveys using geophysical techniques, such as gravity, magnetic, seismic, or radioactivity, which reflect subsurface structures that are of economic or geologic significance. Many maps include correlations with the geology.

Miscellaneous Investigations Series Maps are on planimetric or topographic bases of regular and irregular areas at various scales; they present a wide variety of format and subject matter. The series also includes 71/2-minute quadrangle photogeologic maps on planimetric bases which show geology as interpreted from aerial photographs. Series also includes maps of Mars and the Moon.
Coal Investigations Maps are geologic maps on topographic or planimetric bases at various scales showing bedrock or surficial geology, stratigraphy, and structural relations in certain coal-resource areas.

Oil and Gas Investigations Charts show stratigraphic information for certain oil and gas fields and other areas having petroleum potential.

Miscellaneous Field Studies Maps are multicolor or black-andwhite maps on topographic or planimetric bases on quadrangle or irregular areas at various scales. Pre-1971 maps show bedrock geology in relation to specific mining or mineral-deposit problems; post-1971 maps are primarily black-and-white maps on various subjects such as environmental studies or wildemess mineral investigations.

Hydrologic Investigations Atlases are multicolored or black-andwhite maps on topographic or planimetric bases presenting a wide range of geohydrologic data of both regular and irregular areas; principal scale is $1: 24,000$ and regional studies are at $1: 250,000$ scale or smaller.

\section{Catalogs}

Permanent catalogs, as well as some others, giving comprehensive listings of U.S. Geological Survey publications are available under the conditions indicated below from the U.S. Geological Survey, Books and Open-File Reports Section, Federal Center, Box 25425, Denver, CO 80225. (See latest Price and Availability List.)

"Publications of the Geological Survey, 1879-1961" may be purchased by mail and over the counter in paperback book form and as a set of microfiche.

"Publications of the Geological Survey, 1962-1970" may be purchased by mail and over the counter in paperback book form and as a set of microfiche.

"Publications of the U.S. Geological Survey, 1971-1981" may be purchased by mail and over the counter in paperback book form (two volumes, publications listing and index) and as a set of microfiche.

Supplements for $1982,1983,1984,1985,1986$, and for subsequent years since the last permanent catalog may be purchased by mail and over the counter in paperback book form.

State catalogs, "List of U.S. Geological Survey Geologic and Water-Supply Reports and Maps For (State)," may be purchased by mail and over the counter in paperback booklet form only

"Price and Availabllity List of U.S. Geological Survey Publications," issued annually, is available free of charge in paperback booklet form only.

Selected coples of a monthly catalog "New Publications of the U.S. Geological Survey" available free of charge by mail or may be obtained over the counter in paperback booklet form only. Those wishing a free subscription to the monthly catalog "New Publications of the U.S. Geological Survey" should write to the U.S. Geological Survey, 582 National Center, Reston, VA 22092.

Note.--Prices of Government publications listed in older catalogs, announcements, and publications may be incorrect. Therefore, the prices charged may differ from the prices in catalogs, announcements, and publications. 


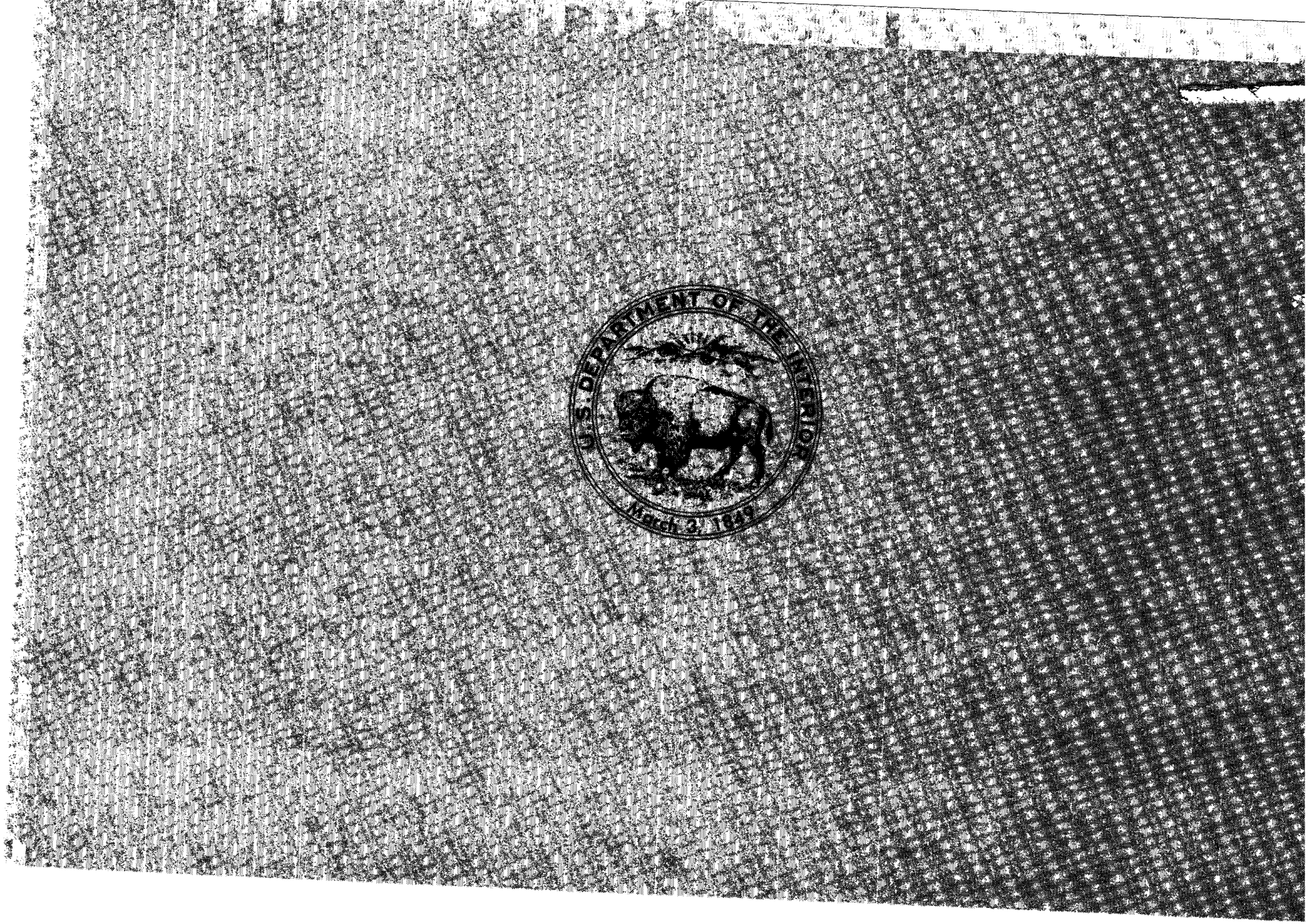

